Sabrina do Nascimento

\title{
O PAPEL DA QUIMIOCINA CXCL12 NA DIFERENCIAÇÃO E AUTORRENOVAÇÃO DE CÉLULAS-TRONCO HEMATOPOÉTICAS
}

\author{
Tese apresentada à Faculdade Israelita de \\ Ciências da Saúde Albert Einstein para \\ obtenção do Título de Doutora em Ciências \\ da Saúde.
}

São Paulo 
Sabrina do Nascimento

\section{O PAPEL DA QUIMIOCINA CXCL12 NA DIFERENCIAÇÃO E AUTORRENOVAÇÃO DE CÉLULAS-TRONCO HEMATOPOÉTICAS}

Tese apresentada à Faculdade Israelita de Ciências da Saúde Albert Einstein para obtenção do Título de Doutora em Ciências da Saúde.

Orientadora: Profa. Dra. Luciana Cavalheiro Marti 
Nascimento, Sabrina do

O papel da quimiocina CXCL12 na diferenciação e autorrenovação de células-tronco hematopoéticas / Sabrina do Nascimento. -- São Paulo, 2021.

xvii, $97 \mathrm{f}$.

Tese (Doutorado) - Faculdade Israelita de Ciências da Saúde Albert Einstein. Instituto Israelita de Ensino e Pesquisa Albert Einstein. Programa de Pós-Graduação em Ciências da Saúde.

Título em inglês: The role of cxcl12 in the differentiation and self-renew in hematopoetic stem cells.

1. Células-tronco hematopoéticas. 2. Quimiocina CXCL12. 3. Célulastronco mesenquimais.

Elaborada pelo Sistema Einstein Integrado de Bibliotecas 
FACULDADE ISRAELITA DE CIÊNCIAS DA SAÚDE ALBERT EINSTEIN

Coordenador do Curso de Pós-Graduação: Prof. Dr. Luiz Vicente Rizzo 


\section{Sabrina do Nascimento}

\section{O PAPEL DA QUIMIOCINA CXCL12 NA DIFERENCIAÇÃO E AUTORRENOVAÇÃO DE CÉLULAS-TRONCO HEMATOPOÉTICAS}

Presidente da banca: Profa. Dra. Luciana Cavalheiro Marti

BANCA EXAMINADORA

Membros titulares:

Profa. Dra. Eliane Antonioli

Prof. Dr. Oswaldo Keith Okamoto

Profa. Dra. Andreza Alice Feitosa Ribeiro

Membros suplentes:

Profa. Dra. Karina Griesi Oliveira

Prof. Dr. Lucas Eduardo Botelho de Souza

Aprovada em: 24/02/2021. 


\section{Agradecimentos}

Primeiramente a Deus, pela criação perfeita e por ter me guiado e sustentado até aqui.

A minha família, mãe, minhas irmãs e companheiro pelo apoio e incentivo. Em especial a minha mãe Maria Vera, uma mulher forte e batalhadora, sem ela, não teria chegado até aqui.

A minha orientadora, Profa. Dra. Luciana C. Marti, pela grande oportunidade de fazer de seu grupo, pela confiança, paciência e por todos os ensinamentos, que foram fundamentais para meu crescimento profissional e pessoal.

A todos os meus colegas e amigos que conquistei durante a realização deste trabalho, em especial a Dra. Fernanda Agostini e Dra. Fernanda Mansur, pelo compartilhamento de conhecimento, apoio e amizade.

Ao grupo da Profa. Dra. Érika B. Rangel, pelo apoio e colaboração com os experimentos com camundongos, em especial ao Christian S. Silva e Expedito Casaro que, além de apoio técnico, ao longo da caminhada, resultou numa grande amizade.

Ao Instituto Israelita de Ensino e Pesquisa Albert Einstein pela disponibilidade de estrutura física, apoio e a todos que contribuíram para a realização deste projeto. 
"Foco é muitas vezes uma questão de decidir o que você não vai fazer" John Carmack 


\section{Sumário}

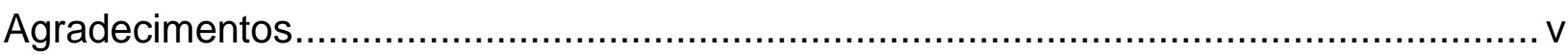

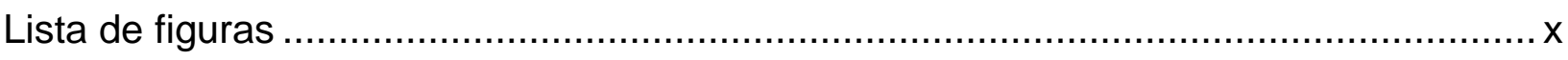

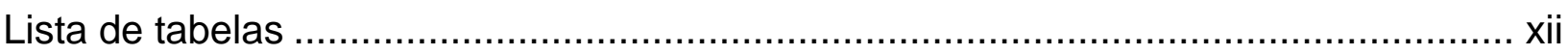

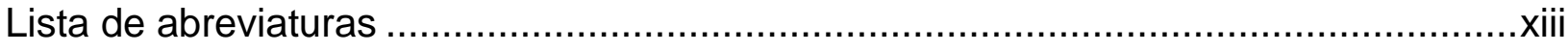

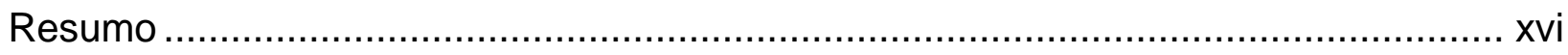

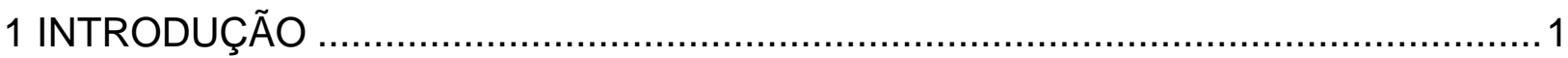

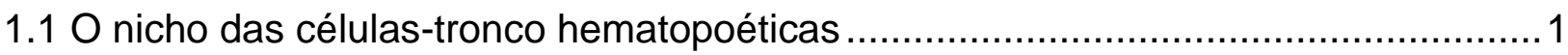

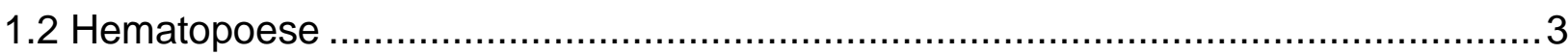

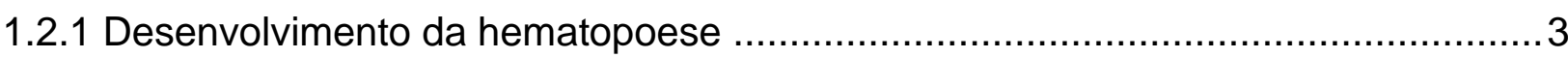

1.2.2 Controle da diferenciação de células-tronco hematopoéticas durante a

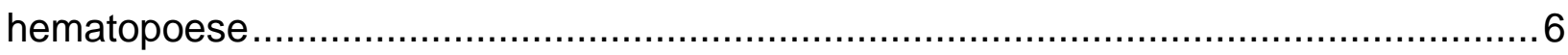

1.3 Células perivasculares estromais no nicho medular ........................................ 8

1.3.1 Células-tronco mesenquimais .................................................................. 8

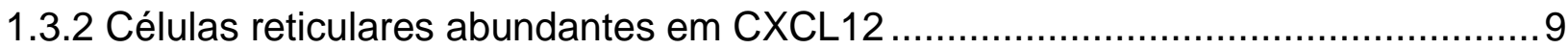

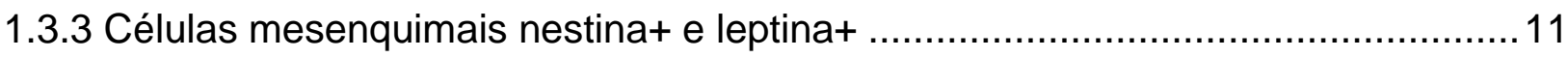

1.4 CXCL12 / CXCR-4 .............................................................................. 14

1.5 Via de sinalização Wingless ................................................................... 16

1.6 Envelhecimento do nicho medular e CXCL12 .............................................. 19

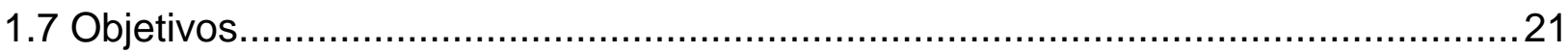

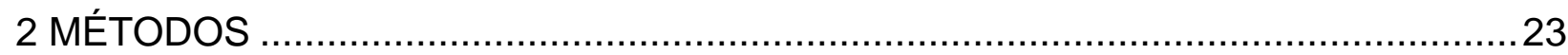

2.1 Delineamento experimental: passado, presente e futuro.................................23

2.2 Soluções e meios de cultura............................................................... 23

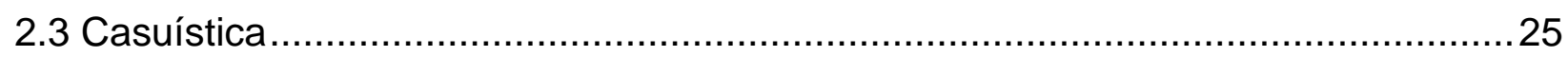

2.4 Obtenção de células linfomononucleares do sangue de cordão umbilical .............26

2.5 Obtenção de células-tronco hematopoéticas.............................................26

2.6 Caracterização imunofenotípica de células-tronco hematopoéticas humanas ........27

2.7 Caracterização das células-tronco mesenquimais por citometria de fluxo .............28

2.8 Diferenciação das células-tronco mesenquimais em 3 linhagens mesodérmicas ...29

2.8.1 Protocolo de diferenciação adipogênica .................................................29

2.8.2 Protocolo de diferenciação e de evidenciação da diferenciação osteogênica .......30

2.8.3 Protocolo de diferenciação e de evidenciação da diferenciação condrogênica....30 
2.9 Cultivo de células-tronco hematopoéticas com ou sem tratamento de CXCL12 .....31

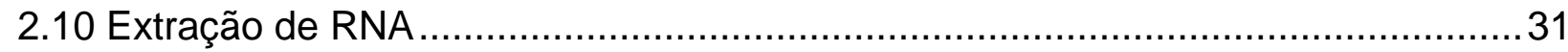

2.11 Síntese de cDNA - reação de transcrição reversa ........................................ 32

2.12 Cocultivo de células-tronco mesenquimais e células-tronco hematopoéticas ........32

2.13 Síntese de cDNA - amplificação completa do transcriptoma ............................. 32

2.14 Desenho dos oligonucleotídeos iniciadores/primers..................................... 33

2.15 Realização dos ensaios de reação em cadeia da polimerase em tempo real .......34

2.16 Padronização dos primers e curvas de eficiência - Reação em cadeia da polimerase

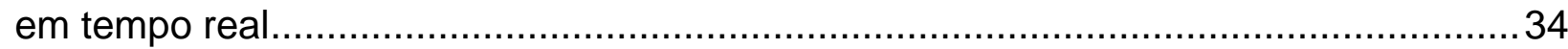

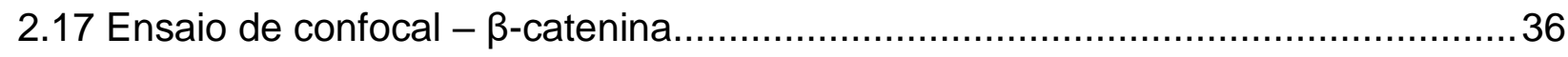

2.18 Padronização do ensaio de silenciamento de mRNA e proteína (CXCL12) ..........37

2.18.1 Ensaio de transfecção em células-tronco mesenquimais humanas - siRNA ..... 37

2.18.2 Detecção da quimiocina CXCL12 ...................................................... 39

2.18.2.1 Citometria de Fluxo - Proteína intracelular............................................ 39

2.18.2.2 Ensaio de Imunoabsorção enzimática - Proteína secretada ..........................39

2.18.3 Clonagem das sequências do RNA pequeno em grampo contra o transcrito codificador de CXCL12 em vetor lentiviral .................................................... 40

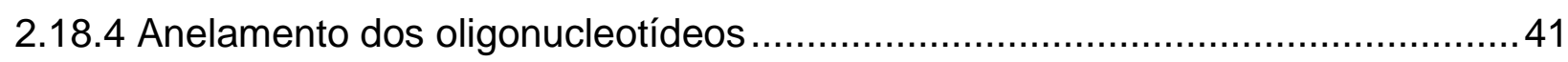

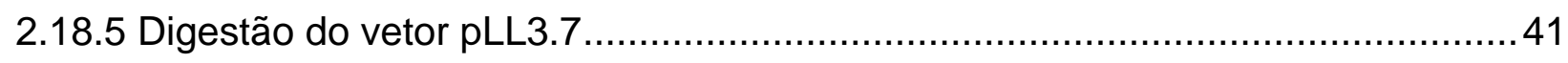

2.18.6 Ligação do RNA pequeno em grampo (short hairpin RNA) ao plasmídeo......... 42

2.18.7 Transformação da reação de ligação em bactérias cálcio competentes ...........42

2.18.8 Confirmação da clonagem por reação em cadeia da polimerase de colônia...... 43

2.18.9 Extração de DNA plasmidial - midiprep ................................................. 43

2.18.10 Transfecção das células HEK-293-T - Confecção do lentivírus ......................44

2.18.11 Ensaio de infecção por lentivírus em células-tronco mesenquimais................45

2.19 Coleta de Medula óssea - Murinos ..................................................... 46

2.20 Cultivo das células-tronco mesenquimais murinas ....................................... 47

2.21 Caracterização imunofenotípica de células-tronco hematopoéticas - Murinos ..... 48

2.22 Padronização do transplante de células-tronco mesenquimais - murinos ............48

2.23 Citometria de fluxo para avaliação da técnica de transplante de células-tronco mesenquimais - camundongos Rosa26/mTmG ............................................. 50

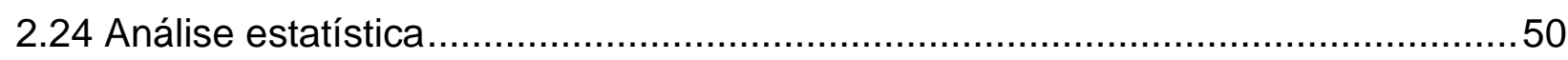

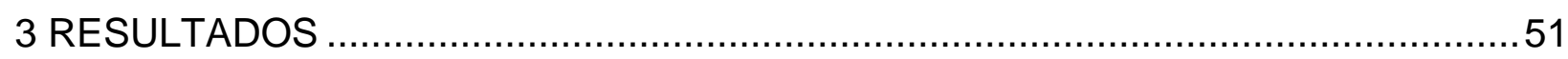

3.1 Caracterização de células-tronco mesenquimais da medula óssea ......................51 
3.2 Caracterização de células-tronco hematopoéticas de sangue de cordão umbilical. 52 3.3 Tratamento in vitro com $\mathrm{CXCL} 12$ aumenta o número de células-tronco hematopoéticas indiferenciadas (CD34+CD38-) …........................................... 52 3.4 Células-tronco hematopoéticas cultivadas com CXCL12 apresentam declínio na expressão de genes relacionados à diferenciação de linhagem hematopoética 54 3.5 Presença de CXCL12 aumenta a expressão gênica de fatores de transcrição relacionados à autorrenovação celular nas células-tronco hematopoéticas in vitro ......55 3.6 CXCL12 contribui para o aumento da expressão proteica da proteína Beta-catenina

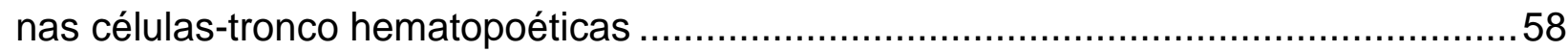

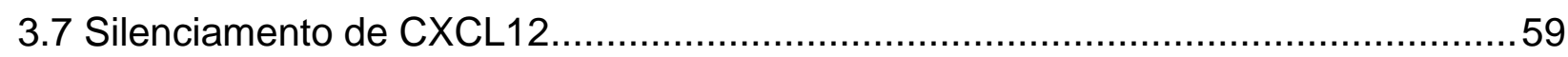

3.7.1 Avaliação da citotoxicidade no ensaio de transfecção em células-tronco

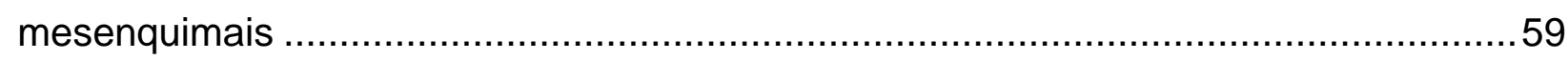

3.7.2 Avaliação da eficiência no ensaio de transfecção - siRNA ................................60

3.7.3 Transfecção versus transdução em células-tronco mesenquimais .......................62

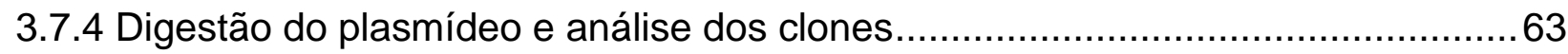

3.7.5 O agente de transfecção siPORT® NeoFx ${ }^{\mathrm{TM}}$ não foi eficiente para transfecção de

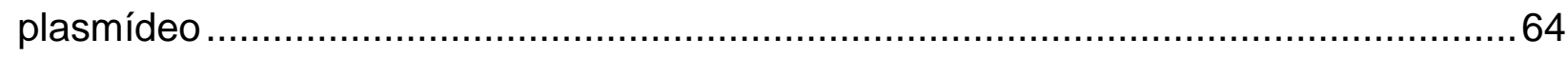

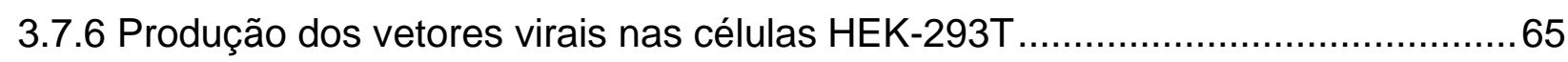

3.7.7 A eficiência da infecção por lentivírus em células-tronco mesenquimais foi acima de $94 \%$ 66

3.8 Camundongos jovens possuem mais células-tronco hematopoéticas indiferenciadas quando comparados a camundongos idosos 68

3.9 Avaliação da técnica de transplante de células-tronco mesenquimais - camundongos

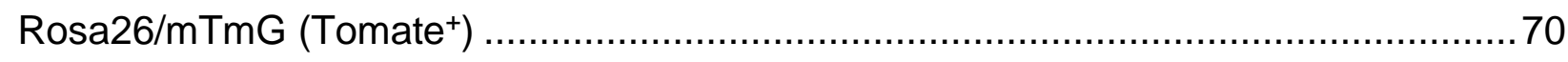

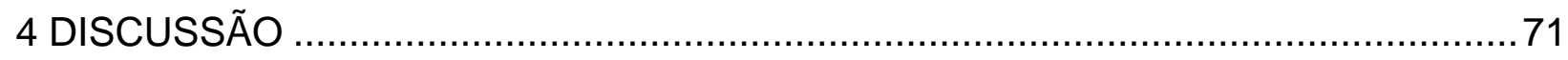

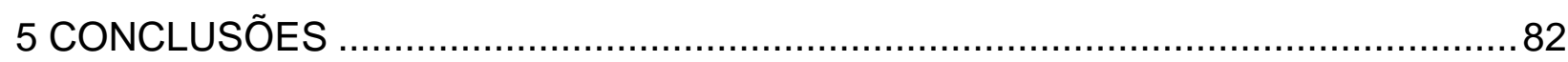

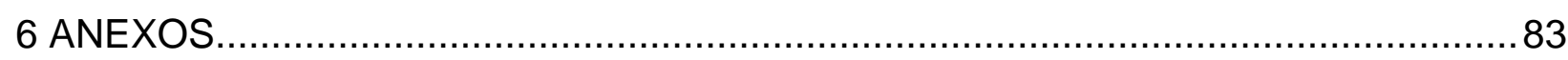

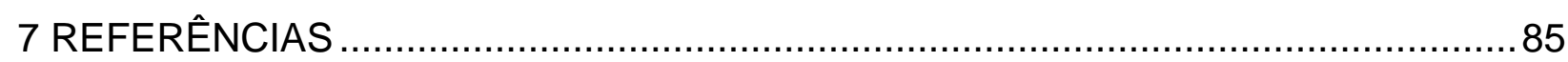

Abstract

Apêndices 


\section{Lista de figuras}

Figura 1. llustração dos diferentes nichos de células-tronco hematopoéticas e gradiente da quimiocina CXCL12 na manutenção dos progenitores hematopoéticos ....................3

Figura 2. Desenvolvimento da hematopoese no camundongo ..................................

Figura 3. Fatores de Transcrição na Hematopoese e divisão assimétrica de célulastronco hematopoéticas.....

Figura 4. Principais tipos de células envolvidas na regulação da manutenção de célulastronco hematopoéticas .14

Figura 5. Sinalização CXCL12 e CXCR4-CXCR7 .................................................16

Figura 6. Via de sinalização canônica Wingless ........................................................17

Figura 7. $O$ nicho das células-tronco hematopoéticas na medula óssea durante o

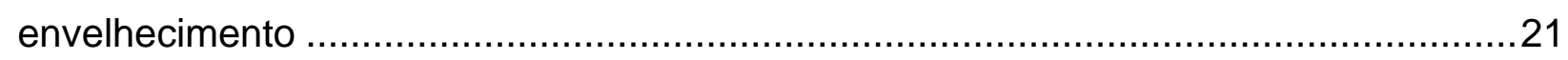

Figura 8. Delineamento experimental: passado, presente e futuro..............................23

Figura 9. Curva padrão, de eficiência e Melting mostrando a eficiência do primer GAPDH, utilizado como controle endógeno .35

Figura 10. Curva padrão, de eficiência e Melting mostrando a eficiência do primer

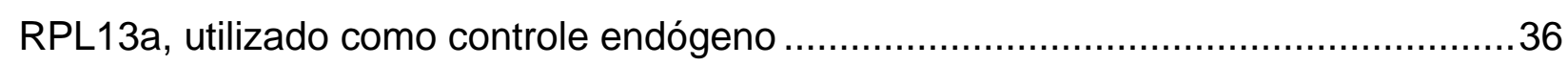

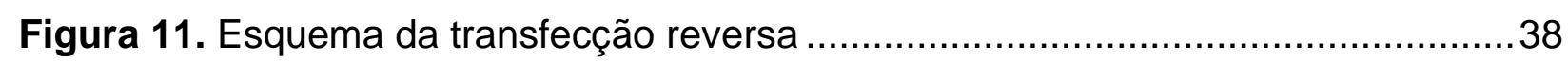

Figura 12. Mapa do plasmídeo utilizado para clonagem dos shRNAs ........................42

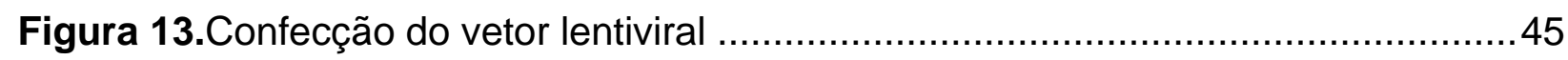

Figura 14. llustrações do procedimento de coleta de células da medula óssea de

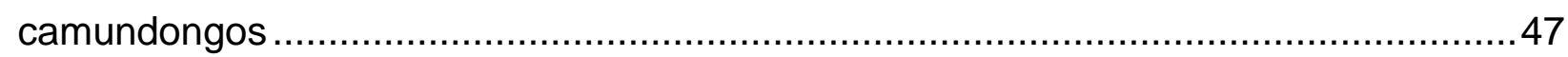

Figura 15. llustrações do teste com injeção do corante na medula e do procedimento de injeção das células-tronco mesenquimais na medula óssea.

Figura 16. Caracterização do perfil das células mesenquimais ...................................51

Figura 17. Perfil de expressão fenotípica de células-tronco hematopoéticas isoladas de sangue de cordão umbilical após seleção CD34.

Figura 18. CXCL12 induz aumento no número absoluto de células-tronco hematopoéticas indiferenciadas CD34+CD38-....

Figura 19. Tratamento com CXCL12 induz redução na expressão gênica dos fatores de transcrição ligados à diferenciação de linhagem hematopoética nas células-tronco hematopoéticas . 
Figura 20. Expressão dos genes relacionadas a multipotência nas células-tronco hematopoéticas com e sem tratamento de CXCL12 …........................................57

Figura 21. Expressão gênica e proteica da proteína Beta-catenina nas células-tronco hematopoéticas após tratamento com CXCL12

Figura 22. Expressão gênica remanescente de CXCL12 após silenciamento com siRNA

Figura 23. Expressão intracelular de CXCL12 após o silenciamento com siRNA 61

Figura 24. Expressão de CXCL12 secretado após o silenciamento com siRNA .62

Figura 25. Perfil eletroforético do plasmídeo pLL3.7 após digestão 63

Figura 26. Análise dos clones após amplificação por reação em cadeia da polimerase .64

Figura 27. Fotografia das células-tronco mesenquimais transfectadas com vetor pLL3.7 utilizando siPORT® NeoFx ${ }^{\text {TM }}$ .65

Figura 28. Fotografias das células HEK-293T após 24 de infecção por lentivírus contendo o plasmídeo - shRNA controle .66

Figura 29. Fotografias das células-tronco mesenquimais infectadas por lentivírus e gráficos da citometria de fluxo para quantificação de células GFP+ 68

Figura 30. Análise de células Lin-Ckit+Sca1+em camundongos jovens e idosos 69

Figura 31. Citometria de fluxo, avaliação da técnica de transplante de células-tronco mesenquimais murinas. .70 


\section{Lista de tabelas}

Tabela 1. Casuística das amostras utilizadas no projeto 25

Tabela 2. Painel utilizado na identificação e caracterização das células-tronco hematopoéticas .28

Tabela 3. Painel utilizado na identificação e caracterização das células-tronco mesenquimais .29

Tabela 4. Padronização e eficiência dos primers 33

Tabela 5. Sequências dos oligonucleotídeos correspondentes aos RNA pequeno em grampo (short hairpin RNA) contra o transcrito codificador de CXCL12 41 


\title{
Lista de abreviaturas
}

\author{
5-FU 5-Fluorouracil \\ AGM Aorta gônada mesonéfrica \\ Ang-1 Angiopoetina-1 (Angiopoetin-1) \\ BMP2/4 Proteína morfogênica do osso (Bone morphogenic protein) \\ CAR Células reticulares abundantes em CXCL-12 (CXCL-12 abundant reticular \\ cells) \\ CEUA Comitê de ética de uso animal \\ $\mathrm{CMN}+\quad$ Células mesenquimais nestina+ \\ CMV Citomegalovírus \\ CONCEA Conselho Nacional de Controle de Experimentação Animal \\ CTH-CT Células-tronco hematopoéticas de curto termo \\ CTH-LT Células-tronco hematopoéticas de longo termo \\ CTHs Células-tronco hematopoéticas \\ CTMs Células-tronco mesenquimais \\ DAPI 4',6-diamidino-2-phenylindole \\ DMEM Meio de cultura (Dulbecco's Modified Eagle Medium) \\ DMEM-LG Meio de cultura (Dulbecco's Modified Eagle Medium-Low Glucose) \\ DMSO Dimitilsulfóxido \\ DPBS Tampão salino fosfatado sem cálcio e magnésio (Dulbecco's Phosphate- \\ Buffered Saline) \\ ELISA Ensaio de Imunoabsorção enzimática (Enzyme-linked immunosorbent \\ assay) \\ FMO Fluorescência menos um (Fluorescence Minus One) \\ FMUSP Faculdade de Medicina de São Paulo \\ FT Fator de transcrição \\ FZD Frizzled \\ GFP Proteína verde fluorescente (Green fluorescent protein) \\ HB Hemangioblastos \\ HE Endotélio hemogênico \\ HIAE Hospital Israelita Albert Einstein \\ HOXB4 Proteína homebox 4
}




\begin{tabular}{|c|c|}
\hline HP & Progenitores hematopoéticos \\
\hline IFN-y & Interferon-y \\
\hline ISHAGE & $\begin{array}{l}\text { Sociedade Internacional de Hematoterapia e Engenharia de Enxerto } \\
\text { (International Society for Hematotherapy and Graft Engineering) }\end{array}$ \\
\hline ISCT & $\begin{array}{l}\text { Sociedade Internacional de Terapia Celular (International Society for } \\
\text { Cellular Therapy) }\end{array}$ \\
\hline LB & Luria-Bertani \\
\hline LepR & Receptor de leptina \\
\hline LMM & Células linfomononucleares \\
\hline LRP & Receptor de baixa densidade proteica (Low repector protein) \\
\hline LTRs & Repetições terminais longas \\
\hline MCAM & $\begin{array}{l}\text { Molécula de adesão celular associada ao melanoma (Melanoma- } \\
\text { associated cell adhesion molecule) }\end{array}$ \\
\hline MFI & Média de intensidade de fluorescência \\
\hline MO & Medula óssea \\
\hline NFAT & Fator nuclear de células $T$ ativadas (Nuclear factor of activated $T$-cells) \\
\hline NG2 & Antigeno neuronal/glial 2 (Neural/glial antigen-2 NG2) \\
\hline PBS & Tampão salino fosfatado (Phosphate- Buffered Saline) \\
\hline PCP & Polaridade celular planar (Planar cell polarity) \\
\hline PCR & Reação em cadeia da polimerase (Polymerase Chain Reaction) \\
\hline plpC & Ácido polinosinico (Polyinosinic: polycytidylic acid) \\
\hline PLC & Progenitor linfoide comum \\
\hline RANTES & $\begin{array}{l}\text { Regulado por ativação - Secretado e expresso por linfócitos regular } \\
\text { (Regulated upon Activation, Normal T Cell Expressed and Secreted) }\end{array}$ \\
\hline RT & Transcriptase reversa (Reverse Transcription) \\
\hline SASP & $\begin{array}{l}\text { Fenótipo secretório associado a senescência (Senescence Associated } \\
\text { Secretory Phenotype) }\end{array}$ \\
\hline SCF & Fator de célula-tronco (Stem cell factor) \\
\hline SCU & Sangue de Cordão Umbilical \\
\hline SDF-1 & Fator 1 derivado de célula estromal (Stromal-cell derived factor -1 ) \\
\hline SFB & Soro fetal bovino \\
\hline shRNA & RNA pequeno em grampo (Short hairpin $R N A$ ) \\
\hline siRNA & RNA pequeno de interferência (Small interference $R N A$ ) \\
\hline SNS & Sistema Nervoso Simpático \\
\hline
\end{tabular}


TCLE Termo de Consentimento Livre e Esclarecido

TGF- $\beta \quad$ Fator de crescimento transformador $-\beta$ (Transforming-growth factor $-\beta$ )

TPO Trombopoetina

VCAM-1 Molécula de adesão celular vascular-1 (Vascular cell adhesion molecule-1)

Wnt Wingless 


\section{Resumo}

Introdução: As células-tronco hematopoéticas são células capazes de produzir todas as linhagens sanguíneas ao longo da vida. Na medula óssea, existe um microambiente local estritamente controlado ou nicho que regula a quiescência, proliferação e diferenciação das células-tronco hematopoiéticas. Estudos mostraram que as células-tronco mesenquimais podem regular o nicho de células-tronco hematopoéticas. Embora os mecanismos não sejam totalmente compreendidos, essas células expressam genes associados à manutenção de células-tronco hematopoéticas e sua retenção no nicho, incluindo aqueles que codificam a quimiocina CXCL12 e o fator de células-tronco. Objetivos: Compreender o papel da quiomiocina CXCL12 na multipotência, autorrenovação e diferenciação das células-tronco hematopoéticas humanas, correlacionando o impacto do envelhecimento das células-tronco mesenquimais em modelo de transplante em camundongos. Métodos: Células-tronco hematopoéticas foram tratadas com CXCL12 $(5 \mathrm{ng} / \mathrm{mL})$ e após 3 e 7 dias, análises imunofenotípicas e expressão gênica referente aos processos de diferenciação e autorrenovação foram realizadas. Para análise do silenciamento da CXCL12 nas células-tronco mesenquimais foi utilizado o método de silenciamento por RNA pequeno de interferência e RNA pequeno em grampo de interferência. Para o estudo em modelo animal, utilizamos a técnica de flush medular e comparamos o perfil imunofenotípico de células-tronco hematopoéticas (LSK Lin-cKit+Sca1+) em camundongos jovens e idosos, e isolamos células estromais dos mesmos. Avaliamos o impacto do cocultivo de células-tronco hematopoéticas com células-tronco mesenquimais na expressão gênica da diferenciação. Resultados: $O$ tratamento com CXCL12, foi capaz de manter as célulastronco hematopoéticas em estado indiferenciado ( Lin-CD34 $^{+} \mathrm{CD} 38^{-}$) e contribuiu para redução da expressão de genes relacionados a diferenciação hematopoética e aumento dos genes relacionados a multipotência. A técnica de silenciamento por RNA pequeno de interferência não foi satisfatória para diminuição da expressão do RNA e proteica da quimiocina CXCL12. Houve diferença significativa na porcentagem de células-tronco hematopoéticas (LSK Lin-cKit+Sca1+) de camundongos jovens e idosos. As análises de expressão gênica do cocultivo mostraram aumento significativo na expressão para genes envolvidos na diferenciação hematopoética e queda na expressão dos genes relacionados a multipotência e aumento significativo de $\beta$-catenina. Conclusões: $O$ 
tratamento com CXCL12 contribuiu para manter um estado indiferenciado nas célulastronco hematopoéticas, aumentou a expressão de genes relacionados à multipotência e diminuiu a expressão de genes de diferenciação. Células-tronco mesenquimais são frequentemente utilizadas como suporte para expansão de células-tronco hematopoéticas, entretanto, observamos que contribui para o aumento da expressão genes relacionados à diferenciação e sem impacto nos genes relacionados à multipotência. Os resultados em camundongos contribuiram para o entendimento das alterações no microambiente medular no envelhecimento e para o isolamento de célulastronco mesenquimais.

Descritores: Células-tronco hematopoéticas; Quimiocina CXCL12; Células-tronco mesenquimais 


\section{INTRODUÇÃO}

\subsection{0 nicho das células-tronco hematopoéticas}

As principais propriedades de células-tronco hematopoéticas (CTHs) são multipotência, capacidade de autorrenovação e quiescência. ${ }^{(1)} \mathrm{O}$ microambiente da da medula óssea (MO) parece ser exclusivamente adaptado para suportar estas e outras propriedades das CTHs. Conforme proposto pela primeira vez por Schofield em 1978, o conceito de nicho de células-tronco dentro da $\mathrm{MO}$ ganhou popularidade generalizada. As células especializadas da $\mathrm{MO}$ estão fisicamente associadas às $\mathrm{CTH}$ e fornecem sinais específicos que ajudam a manter sua função. Muitos estudos de revisão reúnem trabalhos que destacam a diversidade de células do estroma da MO que compõem o nicho e os sinais que elas geram para contribuição e para a manutenção de CTHs, conforme ilustrado na figura $1 .^{(2-8)}$

A MO é o principal local de hematopoese na maioria dos vertebrados. ${ }^{(9)}$ Além de células hematopoéticas, a MO compreende células que contribuem para a homeostase óssea, incluindo células-tronco mesenquimais (CTMs), osteoprogenitores, osteoblastos e osteócitos. Além disso, um cenário mais complexo é construído pela presença de outros subtipos de células estromais que residem na medula e podem regular a hematopoese, incluindo células neuronais, células da glia e adipócitos. ${ }^{(2-8)}$

Existe uma rica rede de células estromais intercaladas entre ilhas de células hematopoéticas que geram um gradiente de secreção da quimiocina CXCL12 (Figura 1), entretanto, a localização dos nichos de CTHs na MO continua controversa. Estudos anteriores usando populações de CTHs transplantadas, marcadas através de seus receptores demonstraram localização de prevalência endosteal. Estes dados corroboram Nombela-Arrieta et al., que revelaram que tanto as CTHs mais progenitoras ou as mais comprometidas com linhagem, estavam localizados perto do endotélio com preferência pela região endosteal. ${ }^{(10-12)}$

Entretanto, outros trabalhos guiados por imagens através da identificação de marcadores de superfície das CTHs na MO, sugerem que estas células estão localizadas em grande parte na região perivascular. ${ }^{(13,14)}$ 
Outros estudos focam na colaboração da quimiocina CXCL12 para a localização das CTHs no microambiente medular, também conhecido como fator 1 derivado de célula estromal (SDF1 - stromal-cell derived fator-1), uma quimiocina essencial para a retenção das células progenitoras hematopoéticas na MO. A expressão da quimiocina CXCL12 verificada a partir da atividade de Cre recombinase, onde a deleção desta quimiocina foi condicionada à região promotora da proteína verde fluorescente (GFP - green fluorescent protein), revelam que as células de estroma que mais expressam CXCL12, comumente referidas como células reticulares abundantes em CXCL12 (CAR - CXCL12 abundant reticular cells), são distribuídas em torno dos sinusoides. ${ }^{(15)}$

Diversos estudos identificaram populações específicas de células estromais que regulam distintas populações de progenitores hematopoéticos, agindo como reguladores positivos e negativos da hematopoese. ${ }^{(4)}$ Portanto, é importante ressaltar que, independentemente de sua localização, uma complexa soma de sinais metabólicos, gerados por diferentes populações de células estromais, determinam o destino e as funções das CTHs dentro do nicho da MO. 


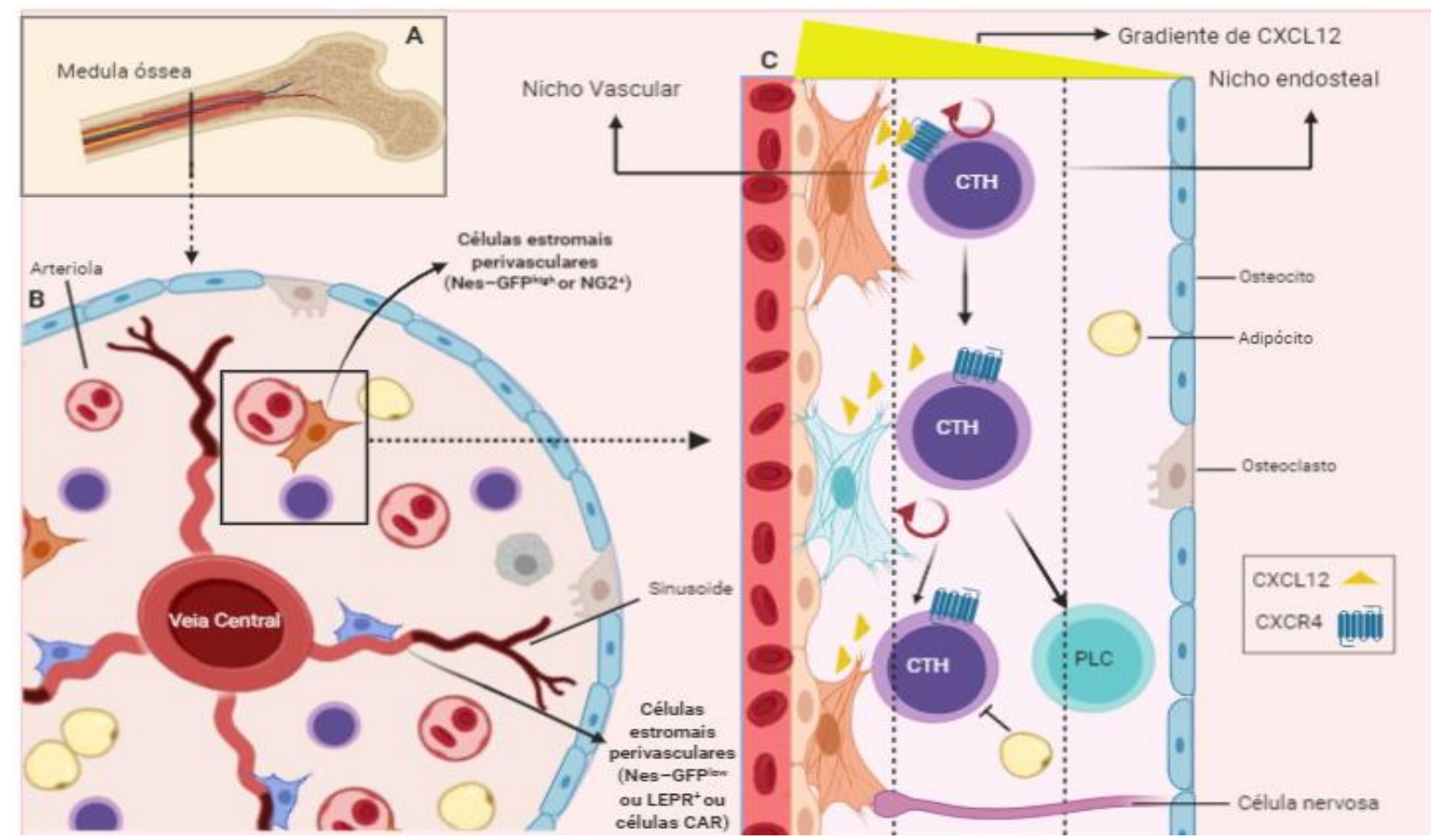

(A) Corte transversal da medula óssea saudável, incluindo medula vermelha e amarela. (B) As regiões perivasculares da $M O$ contêm uma população heterogênea de células estromais caracterizadas pela expressão de CXCL12 em 3 subconjuntos diferentes, uma que expressa níveis elevados de CXCL12 também conhecido como células CAR, outro grupo de células do estroma que expressam Nestina e, células estromais positivas para receptores de leptina (LepR). (C) Gradiente da CXCL12 e a localização das CTHs na medula óssea ainda é controversa, porém, células do estroma podem regular progenitores distintos de células hematopoiéticas, sendo identificados como reguladores positivos e negativos da hematopoese. CTH: células-tronco hematopoéticas; PLC: progenitor linfoide comum.

Figura 1. Ilustração dos diferentes nichos de células-tronco hematopoéticas e gradiente da quimiocina CXCL12 na manutenção dos progenitores hematopoéticos

\subsection{Hematopoese}

\subsubsection{Desenvolvimento da hematopoese}

Durante o desenvolvimento embrionário, a hematopoese ocorre em localizações anatômicas distintas, sendo dividida em dois estágios: o primitivo e o definitivo. A hematopoese primitiva ocorre no período embrionário, e está localizada no saco vitelino, aorta gônada mesonéfrica (AGM) e placenta. Já o estágio da hematopoese definitiva, envolve a colonização do fígado fetal, timo, baço e, finalmente, da MO.(9) O processo de produção do sangue é iniciado a partir de uma célula pluripotente, com capacidade de se autorrenovar e se diferenciar em células progenitoras multipotentes, que originam progenitores oligopotentes que podem estar comprometidos com a linhagem mieloide ou linfoide (Figura 2). 


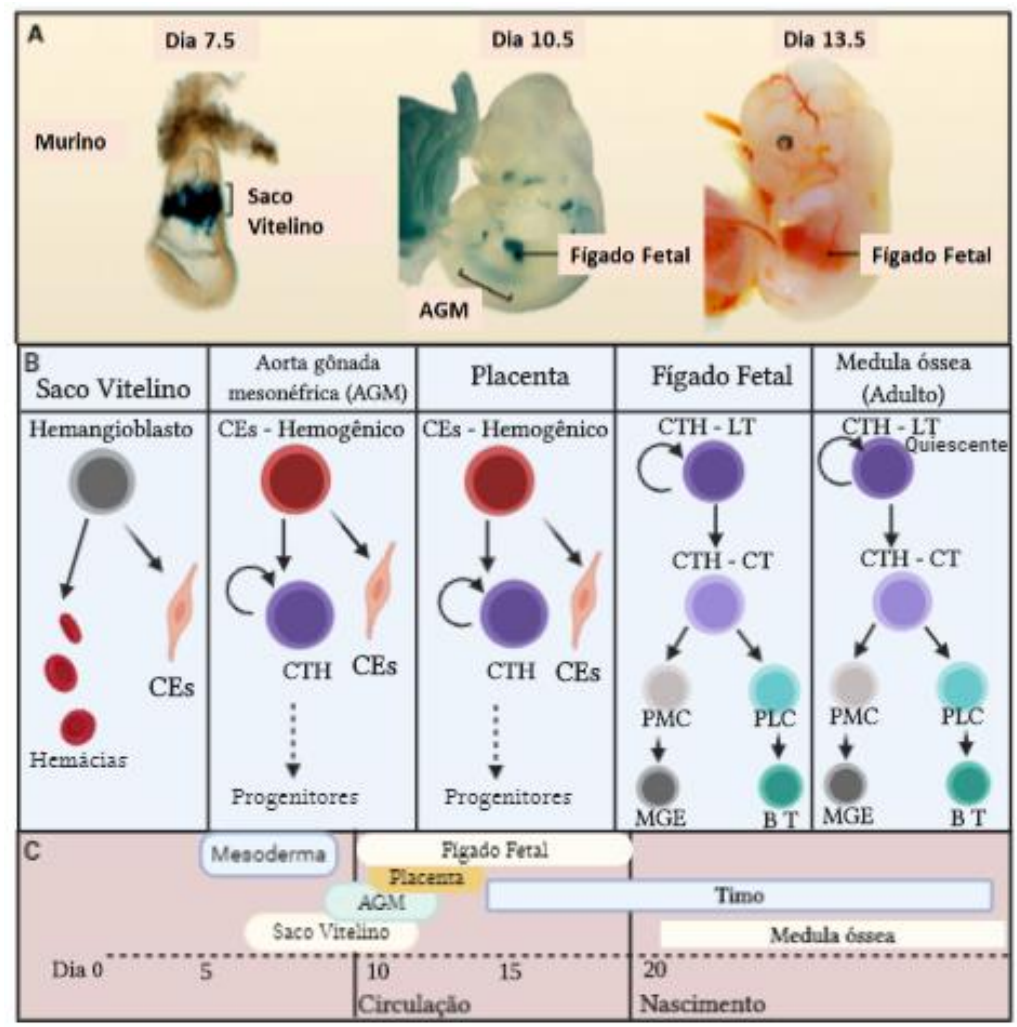

(A) Durante o desenvolvimento embrionário, a hematopoese ocorre primeiramente no saco vitelino, posteriormente na aorta gônada mesonéfrica e fígado fetal. (B) A hematopoese em cada local favorece a produção de linhagens de sangue específicas. (C) Janelas do tempo de desenvolvimento para locais de mudança da hematopoese. CEs: células endoteliais; CTH-LT, células-tronco hematopoéticas de longo termo; $\mathrm{CTH}-\mathrm{CT}$, célulatronco hematopoiética de curto termo; PMC, progenitor mieloide comum; PLC, progenitor linfoide comum; MGE, progenitor de granulócitos/macrófagos e eritroide; $\mathrm{B} \mathrm{T}$, células $\mathrm{B}$ e T.

Fonte: Traduzido e adaptado de Orkin SH, Zon LI. Hematopoiesis: an evolving paradigm for stem cell biology. Cell. 2008;132(4):631-44.(9)

Figura 2. Desenvolvimento da hematopoese no camundongo

No modelo clássico, os progenitores mieloides comuns se diferenciam em células da linhagem mieloide, tais como: monócitos, eritrócitos, megacariócitos, granulócitos macrófagos e células dendríticas. Progenitores linfoides comuns dão origem aos linfócitos T e B, células NK e células dendríticas. ${ }^{(16)}$

Embora o modelo clássico tenha sido muito útil para compreender o processo de diferenciação das CTHs, vale a pena observar que este modelo tem algumas deficiências porque simplifica a complexidade da diferenciação dessas células, com avanços em tecnologia de célula única e modelos genéticos de camundongos, este modelo foi desafiado ao longo dos últimos anos, especialmente na elucidação da megacariopoese e eritropoese. ${ }^{(17,18)}$ 
A chave para a manutenção da homeostase hematopoética são as células-tronco hematopoéticas, com capacidade de divisão assimétrica, ou seja, capacidade de autorrenovação e diferenciação em todas as linhagens de células sanguíneas. Ainda na fase embrionária, os primeiros eritroblastos são formados, mas são derivados da hematopoese transitória e tem como principal função fornecer oxigenação para o embrião, ${ }^{(19)}$ sendo rapidamente substituída. $\mathrm{Na}$ hematopoese definitiva ocorre a produção de células sanguíneas derivadas de células-tronco hematopoéticas onde as células-tronco hematopoéticas de longo termo (CTH-LT) ou pluripotentes proliferam e reduzem seu potencial de replicação, formando as CTHs de curto termo (CTH-CT) ou multipotentes. ${ }^{(20)}$

A hematopoese definitiva é também controlada por sinais ambientais extrínsecos, como fatores de crescimento e outras moléculas de sinalização que serão integradas às moléculas intrínsecas, como fatores de transcrição (FTs), reguladores do ciclo celular e fatores de remodelação da cromatina.

As vias de sinalização como VEGF-Flk-1, Notch, Wnt (Wingless) e a proteína morfogênica do osso BMP4 (bone morphogenic protein 4) ${ }^{(21-23)}$ convergem na expressão de alguns FT. Ainda na fase primitiva, o fator de transcrição Etv2 (ETS related protein $71 E R 71$ ) foi identificado como um regulador chave transcricional durante a transição do mesoderma para hemangioblasto, ${ }^{(24)}$ e esta sinalização é resultado de cascatas reguladoras, incluindo Notch, BMP e Wnt. ${ }^{(25)}$ A transição entre hemangioblasto e endotélio hemogênico também é dependente da expressão de fator de transcrição, o $\mathrm{Scl}$ (Tal-1), o primeiro fator expresso no estágio hemangioblasto e mantido durante outras fases, ${ }^{(26,27)}$ inclusive durante a fase adulta, onde contribui para a manutenção de CTHs e as restringe em G0, preservando a atividade sob condições demanda proliferativa, uma vez que a homeostase hematopoiética ao longo da vida é mantida por um conjunto estável de CTHs, equilibrando-se constantemente entre a autorrenovação e diferenciação, com a maioria das $\mathrm{CTH}$ em repouso (G0) ou quiescente. ${ }^{(28)}$

A saída da quiescência e início de autorrenovação ou proliferação das CTHs é controlada pela combinação de fatores extrínsecos e intrínsecos. Os fatores intrínsecos, como vários fatores de transcrição foram identificados na fase definitiva (adulta), tais como: Ets, Runx1, MLI1, TFIIS, Gata2, Meis1, Erg, FOXO e proteína homebox 4 (HOXB4), sendo que alguns deles reaparecem novamente durante a diferenciação de linhagem (Figura 3A). Estudos demonstram que há participação destes fatores no controle da apoptose, na diminuição das espécies reativas de oxigênio e na 
manutenção da quiescência das CTHs. Especificamente, o aumento da expressão de HOXB4, por meio da utilização de vetores, ampliou a autorrenovação de CTHs enquanto manteve o potencial de diferenciação de várias linhagens. (20,29-31)

As vias de sinalização Wnt/ß-catenina e Notch-Delta influenciam o destino das CTHs, tanto durante a fase primitiva, quanto durante a fase definitiva e/ou adulta, sendo a via Notch responsável pela ativação do fator Runx1 durante hematopoese definitiva ${ }^{(32,33)}$ e, além disso, a sinalização de Notch é um fator chave na inibição da diferenciação e, para a manutenção mediada por Wnt de CTHs indiferenciados, sugerindo que a sinalização Notch pode integrar múltiplos sinais para manter o estado das células-tronco. ${ }^{(9,34)}$

\subsubsection{Controle da diferenciação de células-tronco hematopoéticas durante a hematopoese}

Acredita-se que CTHs adultas sejam predominantemente quiescentes, com estimativas de novas divisões celulares a cada 145 dias. ${ }^{\text {(35) Uma }}$ diferenciação sem divisão provavelmente levaria as CTHs à exaustão, ${ }^{(36)}$ desse modo, as decisões de destino são resultado do tipo de divisão celular, onde a divisão simétrica resulta em duas filhas iguais, garantindo a autorrenovação, enquanto a divisão celular assimétrica resulta em uma célula filha que mantém características de células-tronco e outra progenitora comprometida com linhagem (Figura 3B). Dois tipos de modelos foram propostos para explicar o compromisso de linhagem (Figura 3C-D): modelos instrutivos/específicos que preveem responder a estímulos externos, que guiam diretamente as decisões de linhagem durante diferenciação, ou modelos seletivos/aleatórios, cuja escolha de linhagem é aleatória, provavelmente devido à expressão gênica estocástica, e aos estímulos externos. ${ }^{(36-38)}$ É importante mencionar que esses dois modelos não são mutuamente exclusivos, e parece presumível que eventos extrínsecos possam ser instrutivos e seletivos. Processos intrínsecos celulares, em particular nos quais participam os fatores transcrição, são centrais para a definição do estágio de desenvolvimento e o potencial de linhagem, em resposta a um sinal externo. ${ }^{(31)}$

Além disso, o controle da diferenciação de CTHs é realizado também pela interrupção do estímulo a partir da saída dos FTs, como por exemplo, o fator de 
transcrição PU.1 (codificado pelo gene SPI1) que é necessário para o desenvolvimento de linhagens linfoides e mieloides. Dentro da linhagem mieloide, camundongos deficientes de Spi1 apresentam uma quase completa ausência de macrófagos, neutrófilos e outros granulócitos. ${ }^{(39,40)}$ A participação de PU.1 na modulação da diferenciação das linhagens provavelmente ocorre de forma dose-dependente, ${ }^{(41,42)}$ uma vez que os níveis de PU.1 são maiores na linhagem mieloide em relação aos observados em células $B$. No entanto, diferenças também existem dentre os subtipos de células mieloides, cujas diferenciações ocorrem distintamente dependendo do nível de expressão de PU.1 e da coexpressão de FTs específicos para cada linhagem. ${ }^{(42)} \mathrm{O}$ desenvolvimento de neutrófilos, por exemplo, requer a expressão de uma proteína de ligação ao intensificador CCAAT- $\alpha$ (C/ EBPa), um FT que antagoniza a atividade de transcrição do PU.1, levando à diminuição de sua concentração. Adicionalmente, tal diminuição efetiva, abaixo do limiar requerido para especificação de macrófagos, permite a diferenciação de outras linhagens mieloides. ${ }^{(43,44)}$

Os diferentes níveis de atividade de PU.1 também demonstram ser importantes para a escolha da linhagem entre macrófagos e mastócitos. Altos níveis de expressão de PU.1 favorecem a diferenciação de macrófagos, enquanto níveis intermediários, juntamente com a coexpressão do FT GATA2, favorecem a diferenciação para mastócitos. ${ }^{(40)}$ Além disso, PU.1 também é um fator chave no desenvolvimento de células dendríticas. ${ }^{(45)}$

Como mencionado acima, a família GATA dos FTs também exerce funções na regulação da diferenciação de linhagens hematopoéticas. Camundongos nocaute para GATA1, 2 e 3 morrem ainda no estágio embrionário devido a alterações hematológicas, indicando um papel fundamental destes fatores de transcrição no desenvolvimento hematopoético. ${ }^{(39)}$ GATA1 é especificamente expresso durante o desenvolvimento de linhagens de células eritroides e megacariocíticas. ${ }^{(46)}$ A perda deste FT resulta em um aumento acentuado da expressão de GATA2, indicando não apenas que GATA2 compensa parcialmente o GATA1, mas também que GATA1 suprime a transcrição de GATA2 durante a eritropoiese normal. ${ }^{(47)}$ A expressão de GATA2 também é essencial durante a transdiferenciação de progenitores mieloides para basófilos e mastócitos, ${ }^{(48)}$ enquanto pareceu ser dispensável para diferenciação de macrófagos. ${ }^{(49)}$ Já a perda combinada de GATA1 e GATA2 em embriões de duplo nocaute leva a uma quase completa ausência de células eritroides primitivas, sugerindo sobreposição funcional entre estes fatores de transcrição no início da eritropoiese. ${ }^{(50)} \mathrm{O}$ último 
componente da família GATA, o GATA3, é descrito como sendo expresso em linfócitos $T$, ${ }^{(51)}$ mas também participa da regulação da autorrenovação e diferenciação de CTHs na MO. (52) No desenvolvimento de células T, o GATA3 tem um papel central desde a geração de progenitores de linhagem $T$, até na diferenciação de células Th2, na especificação de linfócitos T CD4 e no controle da proliferação e manutenção de linfócitos T maduros. ${ }^{(53-56)}$

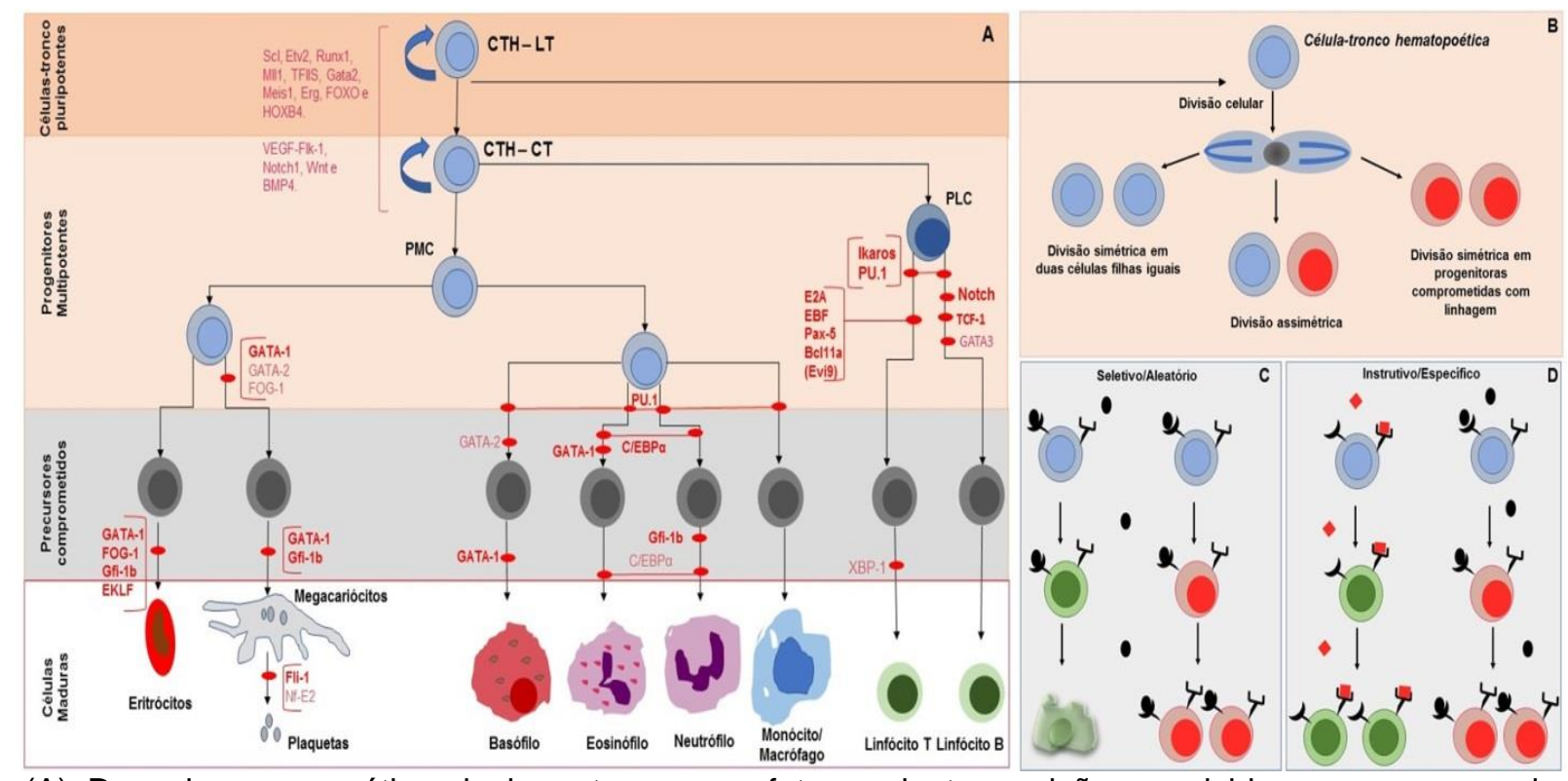

(A) Desenho esquemático da hematopoese e fatores de transcrição envolvidos no processo de diferenciação de CTHs. Estão indicados em vermelho os fatores de transcrição associados à oncogênese. (B-D) Esquema de divisão assimétrica de CTHs e modelos propostos para explicar o compromisso de linhagem, modelos seletivos/aleatório e modelos instrutivos/específicos. CTH-LT: Células-tronco hematopoética de longo termo; CTH-CT: Células-tronco hematopoética de curto termo; PLC: progenitor linfoide comum; PMC: progenitor mieloide comum.

Fonte: Traduzido e adaptado de Orkin SH, Zon LI. Hematopoiesis: an evolving paradigm for stem cell biology. Cell. 2008;132(4):631-44.

Wilkinson AC, Gottgens B. Transcriptional regulation of haematopoietic stem cells. In: Hime G, Abud H, editors. Transcriptional and translational regulation of stem cells. Advances in experimental medicine and biology. Dordrecht: Springer; 2013. p. 187-212.(9,31)

Figura 3. Fatores de Transcrição na Hematopoese e divisão assimétrica de células-tronco hematopoéticas

\subsection{Células perivasculares estromais no nicho medular}

\subsubsection{Células-tronco mesenquimais}

As CTMs, descritas há muitos anos por Friedenstein et al. como células precursoras estromais multipotentes capazes de formar o tecido ósseo existente 
na MO. ${ }^{(57)}$ Estas células, ao serem isoladas e semeadas foram capazes de aderir ao plástico e formar colônias fibroblásticas derivadas de uma única célula. O potencial de autorrenovação e diferenciação foram demonstrados in vivo,(57) sugerindo então a presença de células-tronco estromais na MO. Sendo assim, CTMs ou células-tronco estromais são células precursoras que se autorrenovam e podem se diferenciar em células da linhagem óssea, adipogênica e condrogênica. ${ }^{(58)}$

A Sociedade Internacional de Terapia Celular propôs um critério mínimo de caracterização das CTMs: a) serem aderentes ao plástico; b) expressarem os marcadores de superfície CD105, CD90 e CD73, mas não expressarem os marcadores pan leucocitário (CD45), endotelial (CD31), células precursoras hematopoéticas (CD34), monócitos (CD14 ou CD11b) e células B (CD79a ou CD19) e o HLA de classe II (HLADR); c) as CTMs devem ser capazes de se diferenciarem em osteoblastos, condrócitos e adipócitos. ${ }^{(59)}$

\subsubsection{Células reticulares abundantes em CXCL12}

As quimiocinas pertencem a uma grande família de pequenas citocinas quimioatraentes que foram identificadas pela sua capacidade de controlar a adesão, quimiotaxia e ativação leucocitária. Portanto, sabe-se que estão envolvidas em processos biológicos importantes, como na angiogênese, hematopoese, desenvolvimento embrionário dentre outros. ${ }^{(60)}$ A quimiocina CXCL12 foi caracterizada como um fator de crescimento de células precursoras de linfócitos $B .{ }^{(61)} A$ sinalização entre a quimiocina $\mathrm{CXCL12}$ e seu receptor CXCR-4 é essencial para o homing, manutenção das CTHs e o desenvolvimento das células imunes, incluindo células $B$, células dendríticas plasmocitoides e células NK na MO. ${ }^{(15,61)}$

Camundongos contendo a proteína CXCL12 ligada a um promotor da proteína GFP revelou uma alta expressão de CXCL12-GFP em uma pequena população de células reticulares, denominadas células CAR, as quais estavam distribuídas uniformemente por toda a $\mathrm{MO}$ e possuíam longos prolongamentos que formavam uma rede. ${ }^{(15,62)}$ Neste trabalho, Sugiyama, mostrou que a deleção de CXCL12 condicionada por injeção intraperitoneal de plpC em camundongos adultos resultou em redução no número de CTHs e um aumento na sensibilidade a dano mielotóxico, embora não impedisse a proliferação de fenótipos mais maduros. A maioria das CTHs foram 
encontradas em contato íntimo com as células CAR, estas por sua vez, foram encontradas circundando as células endoteliais sinusoidais ou próximas ao endósteo. A sinalização CXCL12-CXCR4 tem papel importante na manutenção do "pool" de CTHs quiescentes, e as células CAR parecem ser componente chave do nicho vascular e endosteal na MO adulta. Entretanto, 97\% das CTHs (CD150+ CD48- CD41-), células precursoras de linfócitos $B$, células plasmáticas, dendríticas plasmocitoides e células NK também estavam em contato com os prolongamentos das células CAR na medula. Este resultado sugere que as células CAR interagem não apenas com as CTHs, mas também com células imunes produzidas na MO. ${ }^{(15,63-65)}$

Para avaliar a função das células CAR in vivo, Omatsu et al. utilizaram um modelo animal, no qual as células CAR foram depletadas. Tal deleção foi associada a uma redução no número e no tamanho das CTHs, que apresentaram um fenótipo mais quiescente e expressaram genes da linhagem mieloide. Além disso, o número de células B e progenitores eritroides também foi reduzido com a deleção das CAR. ${ }^{(66)}$

Outros estudos apontam que células perivasculares da $M O$ que expressam a molécula de adesão celular associada ao melanoma (MCAM - melanoma associated cell adhesion molecule), também chamada de CD146, são progenitores estromais. ${ }^{(67)}$ Este subtipo de células CD146+ também expressam o PDGFR- $\alpha$, CD51 e o filamento de proteína nestina, estão localizadas próximas às fibras do nervo adrenérgico e apresentam a capacidade de formar colônias fibroblásticas, além de expressarem genes mediadores da manutenção e retenção das CTHs como, por exemplo, os que codificam a quimiocina CXCL12 e o fator de célula-tronco (SCF - stem cell fator). A caracterização dessas células indica que elas apresentam um perfil de expressão de genes e de proteínas de membrana semelhantes às células CAR presentes em camundongos. ${ }^{(14,68)}$ Ding e Morrison avaliaram a expressão de CXCL12 através da atividade de Cre recombinase, onde a deleção desta quimiciona foi condicionada por injeções de tamoxifeno e direcionada através de regiões promotoras especificas de células estromais perivasculares, células endoteliais e osteoblastos na MO. Com a deleção, mostraram que a expressão de CXCL12 encontrava-se em maior prevalência em células estromais perivasculares e, em níveis mais baixos nas células endoteliais, assim como em osteoblastos e células hematopoéticas. Em relação aos efeitos sobre as CTHs, foi observado que a deleção de CXCL12 em células endoteliais diminuiu a frequência de CTHs, em contrapartida, a deleção em osteoblastos reduziu a frequência de progenitores linfoides. ${ }^{69)}$ 
Outro estudo, em desacordo com o Ding e Morrison, revelou que a deleção de CXCL12 em osteoblastos não tem efeito sobre CTHs ou progenitores linfoides. Entretanto, a deleção de CXCL12 em células estromais que expressam osterix, que incluem células reticulares e células $C A R$, resulta em mobilização constitutiva de CTHs e perda de progenitores linfoides de células $B$, mas não alteram a função de CTHs. Surpreendentemente, também mostraram que a deleção condicional utilizando Prx-cre de CXCL12 em progenitores mesenquimais negativos para nestina está associada à perda acentuada de CTHs, perda da atividade de repopulação, diminuição de quiescência e de progenitores linfoides comuns. ${ }^{(70)}$

Portanto, esses dados sugerem que as células CAR e as células $\mathrm{CD}_{146}{ }^{+}$são progenitores adipo-osteogênico essenciais para a proliferação de células $\mathrm{B}$, progenitores eritroides e CTHs, além de participarem da manutenção e retenção de células $\mathrm{CTH}$ s indiferenciadas e que, embora, as células perivasculares sejam as células que mais secretam CXCL12, outras células presentes no nicho medular também secretam esta quimiocina, contribuindo em conjunto para as funções das CTHs.

\subsubsection{Células mesenquimais nestina+ e leptina+}

A nestina é um filamento de proteína intermediário que foi identificado como um marcador de progenitores neurais. ${ }^{(71)}$ Estudos mostraram que algumas células perivasculares estão associadas às fibras do nervo adrenérgico do Sistema Nervoso Simpático (SNS), parecem estar envolvidas com a mobilização das CTHs e são responsáveis pelo número destas células circulantes no sangue periférico de acordo com as oscilações circadianas. ${ }^{(72,73)}$

Mendez-Ferrer et al. identificaram em modelo murino uma população de células mesenquimais que expressa nestina e que está associada às CTHs. As células mesenquimais nestina ${ }^{+}\left(\mathrm{CMN}^{+}\right)$são definidas como células estromais perivasculares que estão localizadas nas áreas centrais da MO, mas também podem ser encontradas nas proximidades do endósteo, porém, em baixa frequência. As $\mathrm{CMN}^{+}$estão espacialmente associadas a CTHs e fibras nervosas adrenérgicas e possuem alta expressão de genes de manutenção de CTHs. Além disso, têm alta expressão de adrenoceptores- $\beta 3$, assim como de $C X C L 12$ que foi 50 vezes mais elevada em células positivas para nestina quando comparado com células negativas, provavelmente, 
ocorrendo uma sobreposição de células positivas para nestina e células CAR. A depleção de células nestina ${ }^{+}$in vivo reduziu rapidamente o número de $\mathrm{CTH}$ na $\mathrm{MO}$, além de reduzir significativamente o homing de progenitores hematopoéticos para a MO após transplante, confirmando a participação de células nestina ${ }^{+}$na reconstituição da população de CTHs pós transplante. Adicionalmente, camundongos transplantados tiveram CTHs residindo próximas a $\mathrm{CMN}^{+}$na MO. ${ }^{(14)}$

Ding et al. mostraram que o receptor de leptina (LepR) também é expresso em células estromais perivasculares da $\mathrm{MO}$, similares às células CAR. As células estromais que expressam receptores de leptina, também produzem CXCL12 e SCF. Baseando-se nessas afirmações, os autores removeram o gene que codifica o SCF nas células leptina+ e observaram redução no número de CTHs, indicando que estas células também são importantes componentes celulares para nicho de células-tronco da MO. ${ }^{(74)}$

Kunisaki et al. a fim de postular existência de dois nichos na MO, endosteal e vascular, utilizaram um novo método tridimensional de imagem combinado com modelagem computacional. Este novo método permitiu identificar nichos vasculares distintos, arterial perivascular e reticular (sinusóide), mediando quiescência (nicho arterial) e a proliferação (nicho sinusóide) das células-tronco, mas não mostrou distribuição endosteal para estas células. Em relação a marcadores celulares, eles observaram que as células perivasculares que expressam LepR são uma importante fonte de SCF, necessário para a manutenção de CTH no nicho. Entretanto, devido ao fato das células Nestina+ também expressarem grandes quantidades de SCF, eles avaliaram sobreposição entre as células perivasculares ou reticulares Nestina+ e células $\mathrm{LepR}^{+}$, e observaram que mais de $80 \%$ dessas células se sobrepõem. Entretanto, apenas as células arteriais perivasculares Nestina+ foram capazes de expressar o marcador de pericito Antigeno neuronal/glial 2 (NG2 - neural/glial antigen-2), consequentemente, eles concluem que as arteríolas organizam um nicho crítico que mantém as CTHs em quiescência na medula e são distintas das células presente nos sinusóides, pois além de serem cercadas por nervos simpáticos, camadas de células musculares lisas e componentes da matriz, também transportam sangue do coração sob alta pressão. Tais características traduzem diferenças significativas entre as células arteriais e venulares endoteliais afetando sua influência sobre as CTHs. ${ }^{(75)}$

É provável que as CTHs residam em um nicho perivascular, mas a localização específica desse nicho permanece controversa. Outro estudo mostrou que 
quase todas CTHs ficam em contato com células $\mathrm{Lepr}^{+} \mathrm{e}$ células que expressam altos níveis de CXCL12 e, aproximadamente $85 \%$ de CTHs ficam bem próxima ao sinusoide. Este estudo também mostrou que a maioria das CTHs, quiescentes ou em divisão, ficam distantes de arteríolas. ${ }^{(76)}$

Asada et al. demonstraram que a deleção de CXCL12 ou SCF de todas as células perivasculares marcadas por nestina-GFP depletou as CTHs da MO de camundongos, enquanto a deleção seletiva de CXCL12 de células $\mathrm{NG}^{+}$arteriolares, além de reduzir o número CTHs, alterou sua localização na MO. Em contraste, a deleção de SCF em células LepR ${ }^{+}$, também levou a reduções de CTHs na MO. Estes resultados revelam contribuições distintas das células perivasculares para manutenção de CTHs em nichos vasculares separados. Em adição, também mostrou que células perivasculares quase se sobrepõem completamente em relação à secreção de SCF e CXCL12. Sendo assim, as contribuições diferenciais dos subtipos de células podem não refletir fielmente à complexidade da secreção de fatores do nicho medular. Certamente estudos futuros determinarão até que ponto a heterogeneidade de CTHs é correspondida pela heterogeneidade do nicho. ${ }^{(77)}$

Portanto, arteríolas e sinusoides da MO são acompanhados por células que expressam NG2 e LepR e constituem nichos especializados que regulam a quiescência e proliferação de CTHs. No entanto, a forma como as células do nicho regulam diferencialmente as funções $\mathrm{CTH}$ permanece desconhecida.

No decorrer deste trabalho focaremos principalmente nas funções da quimiocina CXCL12 e na via de sinalização Wnt envolvidas nas funções de CTHs. Entretanto, inúmeros estudos, principalmente em modelos animais, mostram que a regulação e a manutenção das CTHs no nicho medular são dependentes de vários fatores e sinais que ocorrem no microambiente, como por exemplo, as vias de sinalização CXCL12 (SDF-1)/ CXCR4, Mpl/Trombopoetina (TPO), Tie2/Angiopoetina (Ang-1), via de Wnt e Notch, conforme ilustrado na figura 4. 


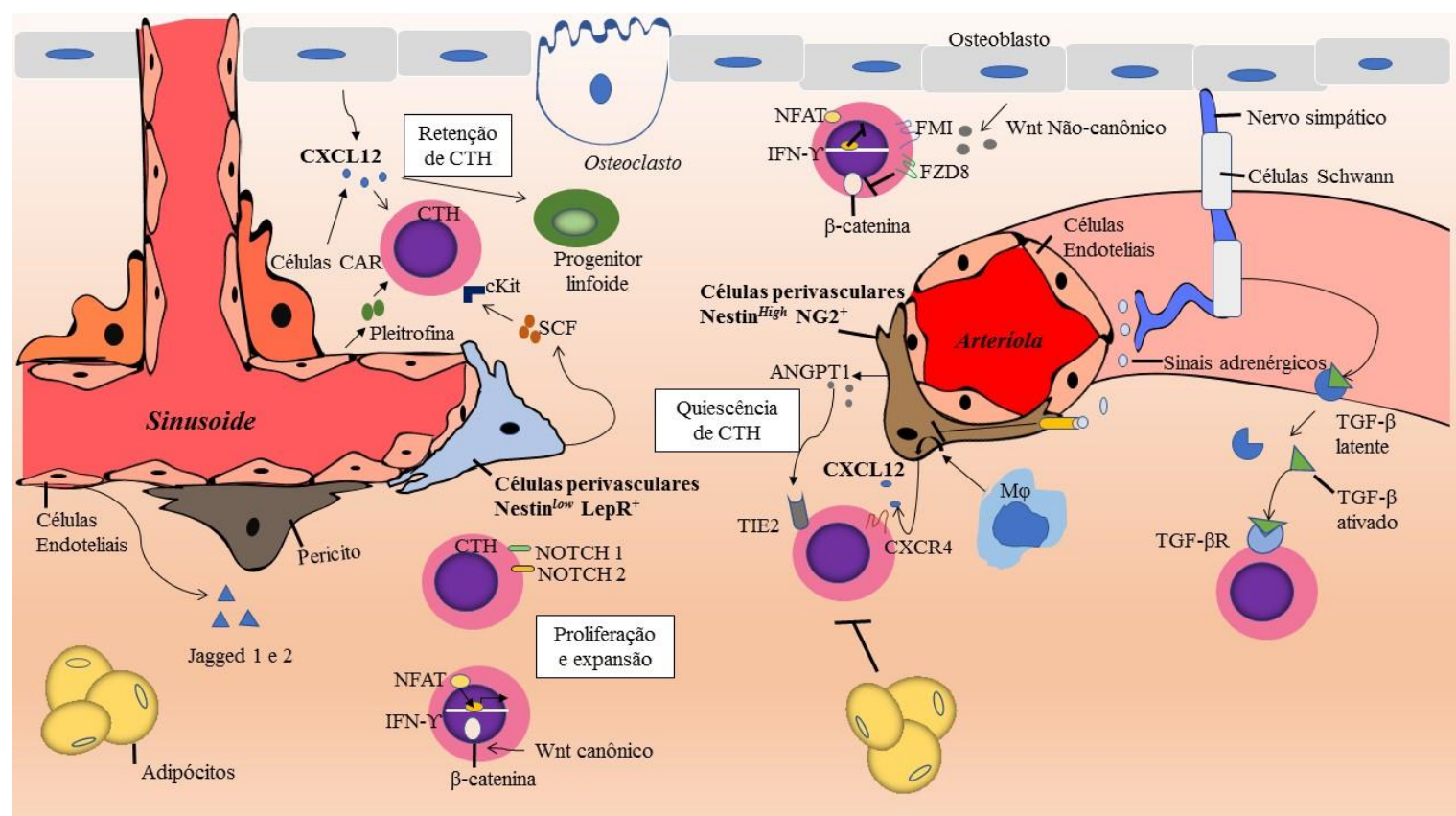

Células implicadas na manutenção de CTHs, incluindo células estromais perivasculares, células endoteliais, macrófagos, células CAR, neurônios simpáticos e células de Schwann não mielinizantes. Alguns reguladores estabelecidos da manutenção de CTHs incluem CXCL12 e SCF, pleiotrofina, angiopoietina 1 (ANGPT1) e TGF- $\beta$ e vias de sinalização incluindo Notch e Wnt. Osteoblastos na regulação das células progenitoras linfoides e adipócitos influenciando negativamente a manutenção de CTHs.

Fonte: Traduzido e adaptado de Mendelson A, Frenette PS. Hematopoietic stem cell niche maintenance during homeostasis and regeneration. Nat Med. 2014;20(8):833-46. (4)

Figura 4. Principais tipos de células envolvidas na regulação da manutenção de células-tronco hematopoéticas

\subsection{CXCL12 / CXCR-4}

A quimiocina CXCL12 em seres humanos e em camundongos é altamente conservada e, seu splicing dá origem a diferentes isoformas, sendo $\alpha$ e $\beta$ as isoformas predominantes e mais presentes. ${ }^{(78,79)} \mathrm{A}$ isoforma CXCL12 $\alpha$ é expressa principalmente na $\mathrm{MO}$, pulmões, linfonodos, coração, timo e fígado, embora possa também ser encontrada na pele e no intestino delgado. A forma precursora pro-CXCL12 contém um peptídeo sinal com 21 aminoácidos na região $\mathrm{N}$-terminal, que é clivado para a secreção da forma madura e biologicamente ativa. ${ }^{(80)}$ Seu receptor CXCR4, inicialmente liga-se aos resíduos 12 a 17 da quimiocina, levando a uma mudança conformacional do receptor que então interage com a porção N-terminal (1 a 8 resíduos) do CXCL12, dos quais os resíduos 1 (Lys) e 2 (Pro) são aqueles diretamente envolvidos na ativação do CXCR4 e consequente sinalização via proteína G. ${ }^{(81)}$

Estudos com camundongos deficientes em CXCL12 ou CXCR4 revelaram que a sinalização CXCL12-CXCR4 é necessária durante a hematopoese, 
formação de vasos sanguíneos no trato gastrointestinal, desenvolvimento cerebelar, formação do septo cardíaco ventricular e viabilidade embrionária. ${ }^{(61,82,83)}$ Além disso, o receptor atípico de quimiocina 3 (ACKR3, também conhecido como CXCR7), é capaz de se ligar ao $C X C L 12$ sinalizando via $\beta$-arrestina e modulando negativamente a atividade de CXCR4. ${ }^{(84,85)}$

Conforme ilustrado na figura 5, o eixo CXCL12/CXCR4 promove a ativação de várias vias de sinalização, incluindo Jak/STAT ou sinalizações via proteína G como: PI3K, MAPK, PLC/PKC, enquanto inibe a adenil ciclase e subsequente formação de CAMP. ${ }^{(86,87)} \mathrm{O}$ mecanismo de ativação de CXCR4 por CXCL12 é mediado pela heterotrimérica proteína $G(G \alpha \beta \gamma)$, que após sua ativação libera as suas subunidades $G a$ e $G \beta \gamma$, tornando-as ativas. A ativação de Gai pode resultar em liberação de cálcio via PLCß, bem como a inibição da adenilato ciclase. ${ }^{\left({ }^{(8)}\right)}$ A proliferação celular pode ser mediada por meio da ativação da PI3K-AKT através das subunidades Ga e/ou Gßy. Além disso, Ga ativada pode promover cascatas de sinalização que levam a ativação Rho/Rac/Ras e PI3K/NFkB induzindo sobrevivência, migração e proliferação celular. ${ }^{(89)}$

O eixo CXCL12/CXCR4 está expresso em células hematopoéticas e endoteliais para estimular processos fisiológicos. Estudos indicam que a interação CXCL12/CXCR4 promove a manutenção e a retenção das CTHs no nicho, e experimentos de inativação ou deleção do receptor CXCR4 em camundongos resultaram na redução das células $\mathrm{CTHs}$ quiescentes levando a proliferação exacerbada das mesmas. ${ }^{(15,90)}$ Tzheng et al. confirmaram o papel da quimiocina CXCL12 na manutenção das CTHs, uma vez que camundongos deficientes de CXCL12 apresentaram diminuição na população de CTHs quiescentes no nicho endosteal.(91) 


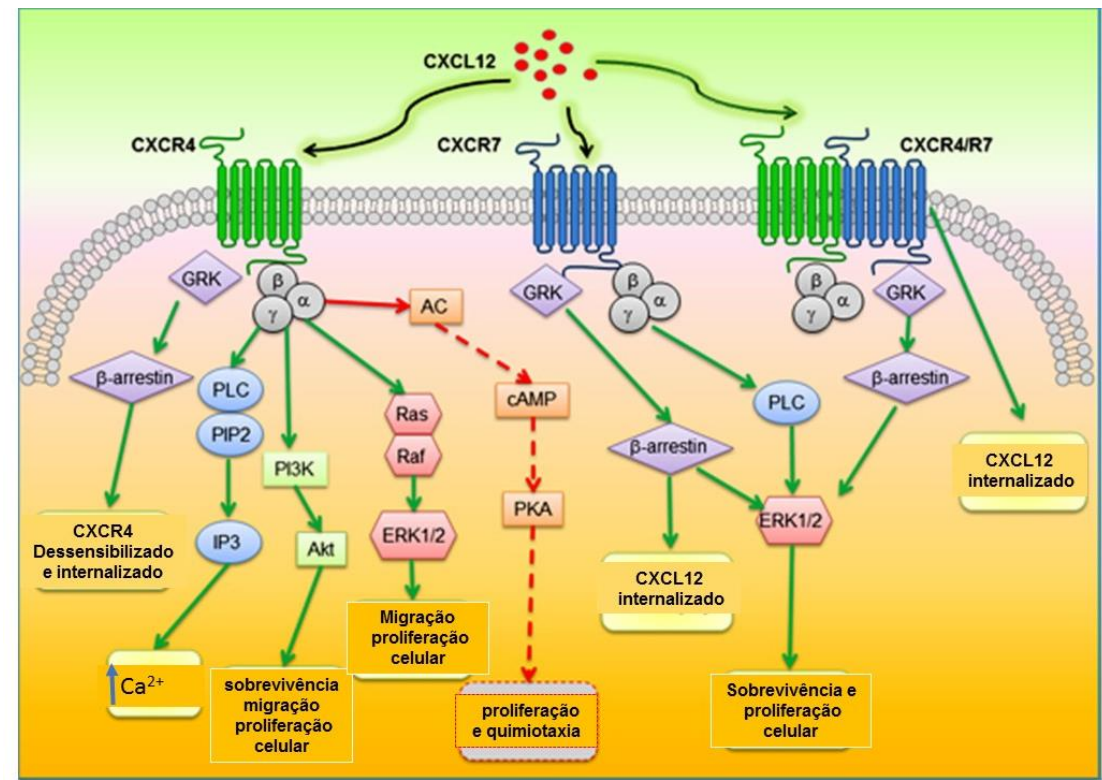

Diagrama esquemático da sinalização CXCL12 e CXCR4-CXCR7 afetando as principais vias de sinalização relacionadas à sobrevivência, proliferação e migração celular.

Fonte: Traduzido de Wurth R, Bajetto A, Harrison JK, Barbieri F, Florio T. CXCL12 modulation of CXCR4 and CXCR7 activity in human glioblastoma stem-like cells and regulation of the tumor microenvironment. Front Cell Neurosci. 2014;8:144. Figure 1, Schematic diagram of proposed CXCR4-CXCR7 crosstalk affecting major signaling pathways related to cell survival, proliferation, and migration; p. 3.(87)

Figura 5. Sinalização CXCL12 e CXCR4-CXCR7

\subsection{Via de sinalização Wingless}

Vários estudos tentam elucidar o papel da via sinalização Wnt na biologia da célula-tronco hematopoética, e existem diferentes modelos e sistemas que indicam a participação da via canônica no aumento da capacidade de autorrenovação destas células. ${ }^{(92,93)}$

A Wnt é uma proteína que participa de vários processos biológicos tais como: migração celular, controle da divisão assimétrica e proliferação. ${ }^{(94,95)}$ Os isotipos Wnt5a, Wnt2b e Wnt10b foram relacionados com a proliferação in vitro de células-tronco humanas e progenitores primitivos. O estímulo de CTHs in vitro com Wnt3a levou ao aumento da atividade em Bcl2 e da capacidade de autorrenovação destas células. ${ }^{(94)}$

Existem pelo menos três vias de sinalização Wnt, sendo uma canônica dependente de $\beta$-catenina, outra conhecida como polaridade celular planar (PCP-planar cell polarity) e a via de cálcio. ${ }^{(96)} \mathrm{A}$ via canônica tem sido muito estudada 
em células do sistema imunológico, onde a $\beta$-catenina é o principal alvo. A formação do complexo $\beta$-catenina-TCF/LEF promove a ativação de genes alvos da Wnt, a proteína $\beta$ catenina está localizada no citoplasma e tem papel importante nas junções aderentes celulares, mas possui vida curta, devido à atividade do complexo de destruição multiproteico, como ilustrado na figura 6. ${ }^{(94)}$

A proteína Wnt se liga a um complexo de receptores, composto pelo receptor Frizzled (FZD) e co-receptor de baixa densidade proteica (LRP5 - LRP6 low repector protein 5 - 6), os níveis celulares de $\beta$-catenina são estritamente regulados por um complexo multiproteico, levando à sua ubiquitinização e a degradação proteassomal. ${ }^{(94)}$
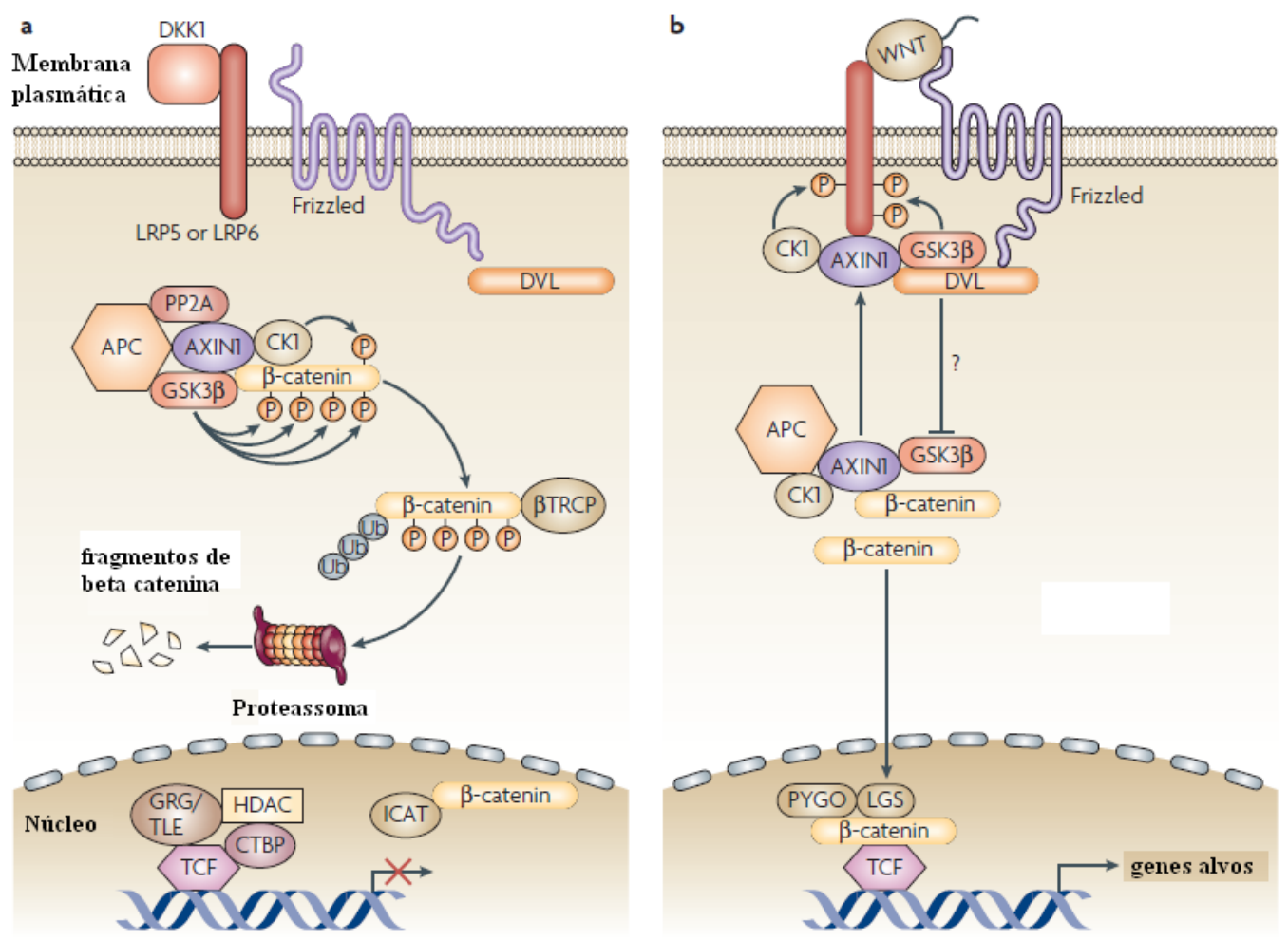

(A) Regulação negativa de sinalização canônica Wnt através da ligação da proteína DKK1 aos co-receptores LRP5/LRP6. (B) Ligação da proteína Wnt ao co-receptor LRP e receptor Frizzled, levando a ativação da via de sinalização canônica.

Fonte: Traduzido de Staal FJ, Luis TC, Tiemessen MM. WNT signalling in the immune system: WNT is spreading its wings. Nat Rev Immunol. 2008;8(8):581-93. Figure 1, Canonical or WNT- $\beta$-catenin-TCF/LEF signaling; p. 583.(96)

Figura 6. Via de sinalização canônica Wingless

Os estudos de ganho de função da $\beta$-catenina que investigaram o papel da Wnt canônica demonstraram que a ativação da $\beta$-catenina nas CTHs levou à expansão da CTHs in vitro, mantendo-as em estado imaturo e promovendo 
reconstituição das diferentes linhagens. ${ }^{(92,93)}$ Por outro lado, um resultado oposto indicou que a ativação constitutiva da $\beta$-catenina usando deleção condicional da proteína $M \times 1$ (pertencem à família das grandes GTPases) em camundongos levou à indução do ciclo celular, diferenciação prejudicada, exaustão e reconstituição reduzida das linhagens após o transplante, seguido de morte. ${ }^{(97,98)}$

Estudos em camundongos mostraram que a deficiência irreversível da proteína Wnt3a, relacionada à via canônica, levou à diminuição de CTHs e progenitoras de longo prazo, além da redução da autorrenovação e da capacidade de repopulação de CTHs provenientes do fígado fetal. ${ }^{(99)}$ Embora o mecanismo subjacente específico ainda não tenha sido descoberto, outros estudos também apoiam um papel importante da via Wnt canônica na regulação da renovação de CTHs, a deleção condicional de $\beta$-catenina usando Vav-Cre ou superexpressão específica de um regulador negativo de Wnt canônico, Dkk1. Tal superexpressão em células osteoblásticas (Col2.3-Cre) resultou em diminuição da reconstituição hematopoética após o transplante e reforçou os efeitos observados do papel da via na autorrenovação de CTHs in vivo. ${ }^{(99)}$ No entanto, a deleção condicional de $\beta$-catenina e $\gamma$-catenina em camundongos $\mathrm{M} \times 1-\mathrm{Cre}$ não afetou a autorrenovação ou a hematopoese após 0 transplante. ${ }^{(100,101)}$ Apesar da deleção tanto da $\beta$-catenina quanto da $y$-catenina, a sinalização Wnt permaneceu presente, sugerindo que um homólogo compensatório da $\beta$-catenina possa existir. ${ }^{(101)}$

Embora a maioria dos estudos tenha investigado a Wnt canônica, também foi sugerido que a via Wnt não-canônica afeta o comportamento de CTHs. Supõe-se que o ligante Wnt5a não-canônico inibe a sinalização Wnt canônica, inibindo a proliferação celular in vitro e aumentando a capacidade de repovoamento de CTHs em modelo murino. ${ }^{(102)}$ As LT-CTHs expressam os membros de sinalizador não-canônico Wnt (Fmi, também chamado Celsr) e 8 frizzled (Fzd8), que promovem quiescência durante a homeostase, impedindo a localização nuclear do fator nuclear de células $T$ ativadas NFAT (nuclear factor of activated T-cells), suprimindo interferon- $\gamma$ (IFN- $\gamma$ ) e antagonizando a sinalização Wnt canônica. ${ }^{(103)}$ Além disso, o estresse em CTHs induzido pela administração do quimioterápico 5-Fluorouracil (5-FU) em camundongos resultou na repressão da sinalização não-canônica de Wnt, resultando em sinalização canônica aumentada. ${ }^{(103)}$ 


\subsection{Envelhecimento do nicho medular e CXCL12}

O envelhecimento influencia negativamente a manutenção das funções das CTHs, aumentando a proliferação e promovendo um potencial de diferenciação transversal. ${ }^{(104,105)} \mathrm{O}$ transplante de CTHs de camundongos idosos em receptores mais jovens revelou que as células envelhecidas tinham uma chance $50 \%$ menor de se diferenciarem e, portanto, menor probabilidade de contribuir para a hematopoese em comparação com as células mais jovens, além disso, a diferenciação tendeu em direção à linhagem mieloide. ${ }^{(106)}$ Com isso, as mudanças mais clinicamente significantes do envelhecimento são o declínio na competência do sistema imune adaptativo, o aumento das doenças mieloides incluindo as mielodisplasias, leucemias e o desenvolvimento de anemias. ${ }^{(107)}$

Embora o mecanismo exato ainda não tenha sido definido para explicar esse fenômeno, dois pontos de vista potencialmente complementares foram sugeridos: a regulação intrínseca e extrínseca. ${ }^{(106,108)}$ Uma perspectiva sobre 0 envelhecimento apoia uma regulação intrínseca das CTHs que resulta em uma diferenciação preferencial de progenitores mieloides e uma capacidade diminuída de produzir progenitores linfoides e células eritroides. ${ }^{(109,110)}$ Essas alterações intrínsecas levam à exaustão das células-tronco e à diminuição da capacidade de repopulação das células hematopoéticas, além de reduzir as taxas de sobrevivência. ${ }^{(107)}$

Outro modelo de envelhecimento sugere uma regulação extrínseca mediada pelo microambiente, que induz um viés de progenitor mieloide comum. ${ }^{(107)}$ Por exemplo, o aumento no nicho medular de camundongos da quimiocina pro-inflamatória CCL5, também conhecida como RANTES Regulado por ativação - Secretado e expresso por linfócitos regular (Regulated on Activation, Normal T Cell Expressed and Secreted) pode contribuir para diferenciação mielóide tendenciosa de CTHs envelhecidas. ${ }^{\left({ }^{8,111)}\right.}$ Outros trabalhos em humanos, demonstraram que CTMs derivadas de doadores idosos apresentaram morfologia senescente, um potencial clonogênico retardado, uma capacidade de proliferação reduzida e aumento na secreção dos fatores com SASP fenótipo secretório associado a senescência (Senescence Associated Secretory Phenotype). Além disso, a exposição de CTHs jovens a fatores secretados por CTHs envelhecidas induziu genes pró-inflamatórios na $\mathrm{CTH}$ e prejudicou o potencial clonogênico de maneira dependente de SASP. ${ }^{(112,113)}$ 
Em favor de um equilíbrio microambiental, as CTHs demonstraram mudar a localização em relação à superfície óssea em camundongos idosos em comparação com animais jovens e localizam-se mais longe do endósteo. ${ }^{(114)} \mathrm{E}$, devido ao envelhecimento, os adipócitos estão cada vez mais presentes no microambiente da $\mathrm{MO}$, que regulam negativamente a hematopoese e atrasam o enxerto. ${ }^{(115)}$

Os camundongos envelhecidos também apresentam número reduzido de células progenitoras mesenquimais localizadas perto da superfície endosteal em comparação com camundongos jovens, prejudicando potencialmente a capacidade de CTHs permanecerem quiescentes. ${ }^{(116)}$ Recentemente, foi demonstrado que o envelhecimento de CTHs também é criticamente depende da inervação da MO pelo SNS. A perda de nervos do SNS ou de receptores adrenérgicos $\beta 3$ no microambiente da MO de camundongos jovens levou ao envelhecimento prematuro de CTHs. ${ }^{(117)}$

Investigações adicionais sobre a interação entre os mecanismos intrínsecos e extrínsecos envolvidos na regulação do envelhecimento por CTHs podem levar a uma base terapêutica para promover o rejuvenescimento das células-tronco. Mudanças intrínsecas frequentemente produzem fenótipos que são complementares aos efeitos do envelhecimento extrínseco, indicando que o fenótipo de envelhecimento do CTHs envolve uma série complexa de fatores e uma linha de comunicação com o nicho (Figura 7). (4)

A diminuição da secreção de CXCL12 pelas células estromais envelhecidas é um ponto relevante envolvendo mudanças extrínsecas no nicho de CTHs, como demonstrado previamente pelo nosso grupo $^{(118)}$ e, recentemente, mudanças relacionadas ao envelhecimento em camundongos também foi associada a diminuição da expressão de CXCL12, SCF e Jagged.(119) Sendo assim, a hipotése do presente projeto é de que a quiomiocina CXCL12 participa da manutenção da multipotência, autorrenovação e diferenciação das células-tronco hematopoéticas humanas. $E$ ainda, que o envelhecimento de CTMs in vivo contribui para dinsfunções de CTHs em camundongos. 


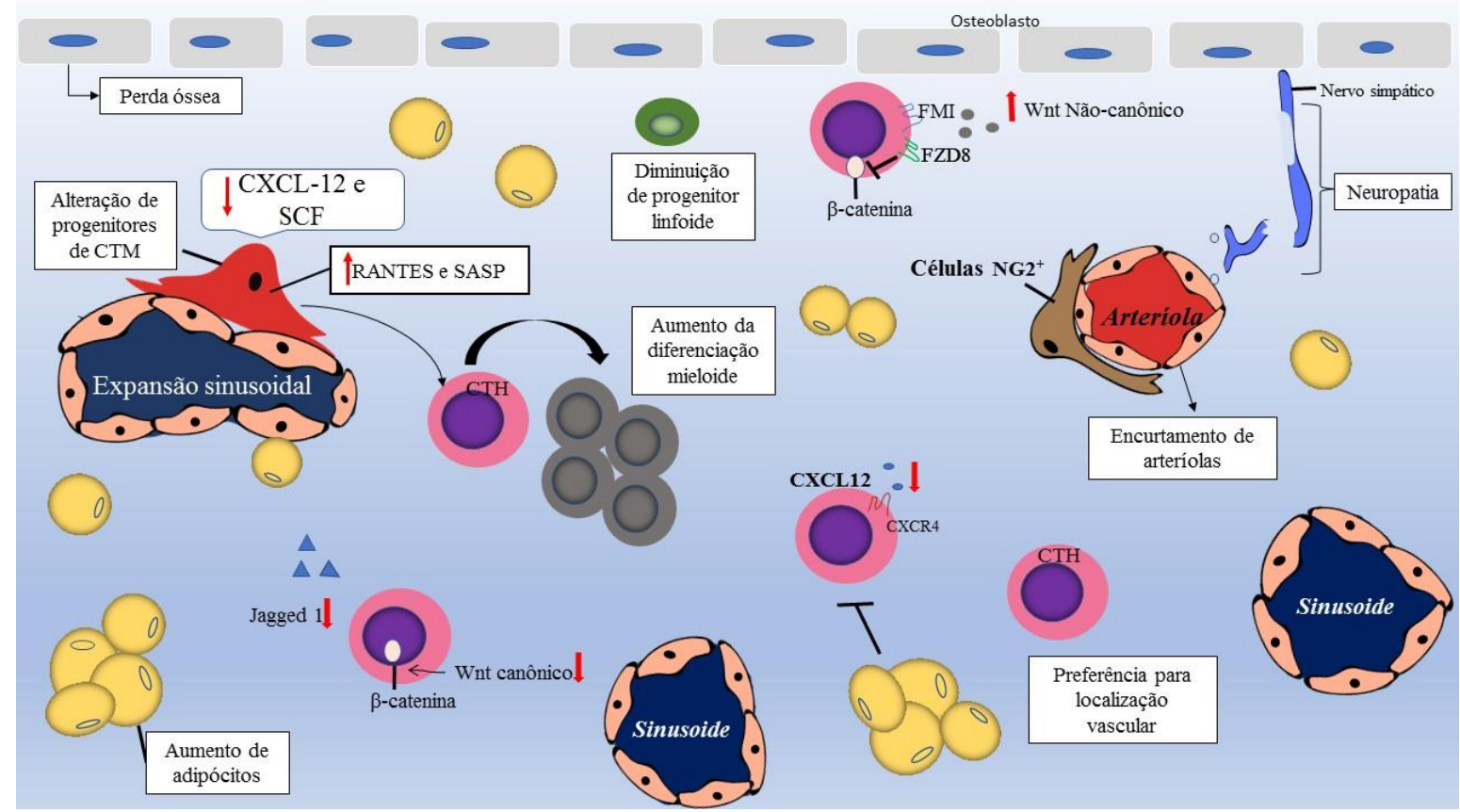

Representação esquemática do nicho de células-tronco hematopoéticas durante o envelhecimento, CTHs envelhecidas exibem diferenciação aumentada para linhagem mieloide. Alterações relacionadas ao envelhecimento do nicho da medula óssea que influenciam o envelhecimento das CTHs incluem alterações na vascularização e nas células-tronco/progenitoras mesenquimais, aumento da adipogênese e redução da osteogênese, secreção alterada de fatores de nicho e um número reduzido de nervos adrenérgicos.

Fonte: Traduzido e adaptado de Pinho S, Frenette PS. Haematopoietic stem cell activity and interactions with the niche. Nat Rev Mol Cell Biol. 2019;20(5):303-20.(8)

Figura 7. O nicho das células-tronco hematopoéticas na medula óssea durante o envelhecimento

\subsection{Objetivos}

1. Avaliar a expressão gênica dos fatores de transcrição relacionados à autorrenovação e diferenciação de linhagem hematopoética após o cocultivo das células-tronco hematopoéticas com células-tronco mesenquimais;

2. Avaliar o papel da quimiocina CXCL12 na autorrenovação e diferenciação de células-tronco hematopoéticas;

3. Avaliar a via Wingless nas células-tronco hematopoéticas cocultivadas com células-tronco mesenquimais e após tratamento com a quimiocina CXCL12;

4. Avaliar o silenciamento da expressão gênica e proteica de CXCL12 nas células-tronco mesenquimais para avaliar sua influência nas células-tronco hematopoéticas;

5. Avaliar o perfil imunofenotípico das células-tronco hematopoéticas em camundongos jovens e idosos; 
6. Expandir células-tronco mesenquimais de camundongos jovens e idosos para ensaios in vivo de avaliação de função destas células no nicho medular. 


\section{MÉTODOS}

\subsection{Delineamento experimental: passado, presente e futuro}

Abaixo, na figura 8 está ilustrado o esquema do delineamento experimental no passado, presente e futuro.

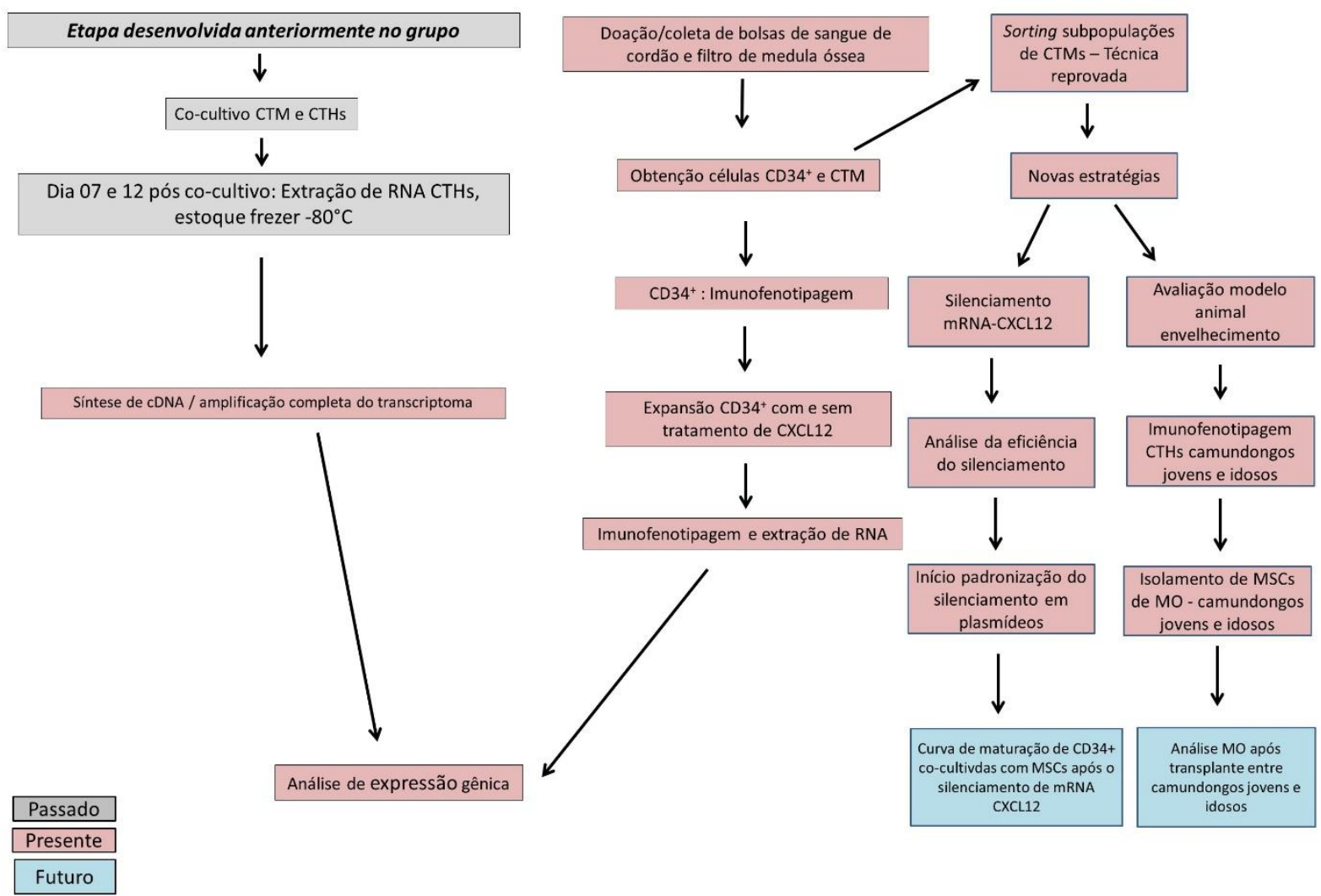

Figura 8. Delineamento experimental: passado, presente e futuro

\subsection{Soluções e meios de cultura}

Meio para congelamento celular (Mc1): DMEM - Dulbecco's Modified Eagle Medium (Gibco, Carlsbad, CA) suplementado com 40\% de soro fetal bovino (SFB - Soro Fetal Bovino) (Gibco, Carlsbad, CA), 1\% de uma solução antibióticoantimicótico composto por 10000 unidades $/ \mathrm{mL}$ de penicilina, $10000 \mu \mathrm{g} / \mathrm{mL}$ de streptomicina e 25 $\mathrm{g} / \mathrm{mL}$ de Gibco anfotericina B (Gibco, Carlsbad, CA), e 1\% de Lglutamina 200mM (Gibco, Carlsbad, CA) com 10\% de Dimitilsulfóxido (DMSO). 
Solução de descongelamento (Mc2): suplementado com 40\% SFB, 12,5Ul/mL de DNase (Invitrogen, Carlsbad, CA), 1\% antibiótico-antimicótico composto por 10000 unidades $/ \mathrm{mL}$ penicilina, $10000 \mu \mathrm{g} / \mathrm{mL}$ estreptomicina, $25 \mu \mathrm{g} / \mathrm{mL}$ de Gibco anfotericina B (Gibco, Carlsbad, CA), e 1\% L-glutamina (200mM).

Tampão para coluna de seleção (T1): PBS - Tampão salino fosfatado (Phosphate- Buffered Saline) pH 7,2, 0,5\% albumina humana e 2 mM EDTA.

Tampão de marcação para citometria de fluxo (T2): DPBS Tampão salino fosfatado sem cálcio e magnésio (Dulbecco's Phosphate - Buffered Saline), 1\% de albumina humana (Grifols, Barcelona, Espanha) e 0,1\% de azida sódica (Sigma, St Louis, MO).

Meio de cultivo para CTH (Mc3): StemSpan H3000 (Stem Cell Technologies, Vancouver, Canada) suplementado com $5 \mathrm{ng} / \mathrm{mL}$ de fator de SCF, $5 \mathrm{ng} / \mathrm{mL}$ de interleucina 6 (IL-6), 5ng/mL de Interleucina-3 (IL-3) e 6,2ng/mL de ligante da tirosina quinase-3 (tyrosina kinase -3 ligand - Flt3-L) (R\&D Systems, Minneapolis, MN).

Meio de cultura para CTM humanas (Mc4): DMEM (Gibco, Carlsbad, CA) suplementado com 10\% de SFB (Gibco, Carlsbad, CA), 1\% de uma solução antibiótico-antimicótico composto por 10000 unidades/mL de penicilina, $10000 \mu \mathrm{g} / \mathrm{mL}$ de streptomicina e $25 \mu \mathrm{g} / \mathrm{mL}$ de Gibco anfotericina B (Gibco, Carlsbad, CA), e $1 \%$ de Lglutamina 200mM (Gibco, Carlsbad, CA) com 10\% de DMSO.

Meio de cultura para CTM - murinos (Mc5): DMEM (Gibco, Carlsbad, CA) suplementado com 20\% de SFB (Gibco, Carlsbad, CA), 1\% de uma solução antibiótico-antimicótico composto por 10000 unidades/mL de penicilina, $10000 \mu \mathrm{g} / \mathrm{mL}$ de streptomicina e $25 \mu \mathrm{g} / \mathrm{mL}$ de Gibco anfotericina B (Gibco, Carlsbad, CA), e 1\% de Lglutamina 200mM (Gibco, Carlsbad, CA) com 10\% de DMSO.

Meio de cultivo para bactéria: Luria-Bertani (LB), composto por: $0,5 \%(\mathrm{~m} / \mathrm{V})$ de extrato de levedura, $1 \%(\mathrm{~m} / \mathrm{V})$ de caldo de triptona de soja e $1 \%(\mathrm{~m} / \mathrm{V})$ de $\mathrm{NaCl}, \mathrm{pH}$ 07. Para preparo de meio LB-líquido, os componentes são diluídos em água Milli-Q e autoclavados. Para preparo de LB-ágar, é adicionado $12 \mathrm{~g}$ de ágar em $1 \mathrm{~L}$ de LBlíquido e autoclavado. Para seleção de colônias, foi adicionado ao meio o antibiótico ampicilina (concentração final de $100 \mu \mathrm{g} / \mathrm{mL}$ ). 


\subsection{Casuística}

As amostras sangue de cordão umbilical (SCU) e MO foram coletadas a partir de procedimentos cirúrgicos, sendo o SCU no momento do parto e MO durante a coleta para doação, seguido pelo isolamento e a caracterização das células utilizadas no estudo.

As células utilizadas no presente estudo estão descritas na tabela $1 \mathrm{e}$ foram obtidas a partir de 13 bolsas de sangue de SCU e 14 filtros descartáveis utilizados durante a coleta de $\mathrm{MO}$ dos quais foram isoladas as CTMs de doadores de MO de idades variadas.

Tabela 1. Casuística das amostras utilizadas no projeto

\begin{tabular}{|c|c|c|c|}
\hline SCU & CTMs & Idades & Experimento \\
\hline $\operatorname{SCU} 11^{*}$ & Hmo 25 & 47 & Cocultivo \\
\hline $\operatorname{SCU} 12^{*}$ & Hmo 34 & 48 & Cocultivo \\
\hline $\operatorname{SCU} 13^{*}$ & Hmo 35 & 22 & Cocultivo \\
\hline & Hmo 37 & 22 & Cocultivo \\
\hline & Hmo 39 & 35 & Cocultivo \\
\hline & Hmo 40 & 49 & Cocultivo \\
\hline \multirow{2}{*}{\multicolumn{4}{|c|}{$\begin{array}{l}\text { * Dia } 07 \text { cocultivo: SCU } 11 \text { e SCU } 12 \\
\text { * Dia } 12 \text { cocultivo: SCU } 11 \text { e SCU } 13\end{array}$}} \\
\hline & & & \\
\hline & Hmo 53 & 27 & Padronização citometria \\
\hline & Hmo 54 & 49 & Padronização citometria \\
\hline & Hmo 55 & 59 & $\begin{array}{l}\text { Padronização de } \\
\text { primers }\end{array}$ \\
\hline & Hmo 56 & 20 & $\begin{array}{l}\text { Padronização de } \\
\text { primers }\end{array}$ \\
\hline & Hmo 57 & 56 & $\begin{array}{l}\text { Padronização de } \\
\text { primers }\end{array}$ \\
\hline & Hmo 58 & 30 & Armazenado \\
\hline & Hmo 59 & 66 & $\begin{array}{l}\text { Padronização } \\
\text { Silenciamento }\end{array}$ \\
\hline & Hmo 60 & 34 & $\begin{array}{l}\text { Padronização } \\
\text { Silenciamento }\end{array}$ \\
\hline SCU 23 & & & Estímulo CXCL12 \\
\hline SCU 24 & & & $\begin{array}{l}\text { Excluído, problemas } \\
\text { técnicos }\end{array}$ \\
\hline SCU 25 & & & $\begin{array}{l}\text { Excluído, problemas } \\
\text { técnicos }\end{array}$ \\
\hline SCU 26 & & & $\begin{array}{l}\text { Excluído, problemas } \\
\text { técnicos }\end{array}$ \\
\hline SCU 27 & & & Estímulo CXCL12 \\
\hline SCU 28 & & & Estímulo CXCL12 \\
\hline SCU 29 & & & Estímulo CXCL12 \\
\hline SCU 30 & & & Armazenado \\
\hline
\end{tabular}




\begin{tabular}{|c|c|c|c|}
\hline & SCU 31 & & Armazenado \\
\hline & SCU 32 & & Armazenado \\
\hline Total & 13 & 14 & \\
\hline
\end{tabular}

\subsection{Obtenção de células linfomononucleares do sangue de cordão umbilical}

Amostras de SCU foram coletadas em bolsas no Centro Obstétrico do Hospital Israelita Albert Einstein (HIAE). As bolsas que não atingiram algum critério de qualidade (número ou volume das células obtidas) do setor de Hemoterapia (HIAE) foram doadas para o presente estudo. A doação ocorreu pelo responsável legal do doador, mediante a assinatura de termo de consentimento livre e esclarecido (TCLE), aprovado pelos comitês de ética em pesquisa do HIAE e da Faculdade de Medicina de São Paulo - FMUSP (Anexo 1), registrado na Plataforma Brasil sob o CAAE número: 21840113.0.0000.0071.

O interior das bolsas foi lavado com meio de cultura DMEM - LG (DMEM-LG Dulbecco's Modified Eagle Medium-Low Glucose) para diluição e retirada do SCU. Tal lavado foi cuidadosamente colocado sobre Ficoll Paque (GE Healthcare, Chicago, IL) com densidade de 1.077 em tubos cônicos que foram centrifugados a $500 \mathrm{~g}$, por 30 minutos, $\mathrm{a} 22^{\circ} \mathrm{C}$.

Após a centrifugação, a interface opalescente contendo a fração de células linfomononucleares (LMN) foi transferida para novo tubo cônico, ressuspendida em PBS, centrifugada por 5 minutos a $500 \mathrm{~g}$ e o sobrenadante posteriormente descartado. Este procedimento foi repetido e as células LMN foram congeladas $\left(5 \times 10^{6} / \mathrm{mL}\right)$ de meio de congelamento (Mc1) e armazenadas a $-80^{\circ} \mathrm{C}$.

\subsection{Obtenção de células-tronco hematopoéticas}

As células LMN de SCU foram descongeladas na solução de descongelamento Mc2. As células foram novamente separadas por gradiente de densidade Ficoll-Paque por centrifugação a $500 \mathrm{~g}$ por 30 minutos, a $22^{\circ} \mathrm{C}$ para obtenção apenas das células LMN vivas. Tais células foram coletadas, lavadas com PBS 1x e centrifugada a $500 \mathrm{~g}$ por 5 minutos, a $22^{\circ} \mathrm{C}$. Foi realizada a contagem/análise da 
viabilidade das células por câmera de Neubauer utilizando o Azul de Tripan (Trypan Blue). Em seguida, as células foram centrifugadas $500 \mathrm{~g}$ por 5 minutos, a $22^{\circ} \mathrm{C}$ e ressuspendidas em $500 \mu \mathrm{L}$ de tampão (T1), centrifugadas a $300 \mathrm{~g}$, por 10 minutos, a $22^{\circ} \mathrm{C}$. O sobrenadante foi descartado e as células foram ressuspensas em $300 \mu \mathrm{L}$ de $\mathrm{T} 1$.

As células-tronco hematopoéticas $\mathrm{CD} 34^{+}$foram separadas de acordo com o protocolo de separação CD34 (Microbead Kit - Human Macs Miltenyi Biotec, Alemanha). As células foram incubadas por 30 minutos a $4^{\circ} \mathrm{C}$ com "microbeads" antiCD34 e FCR "blocking reagent", cujos volumes foram calculados proporcionalmente ao número de células. Posteriormente, as células foram lavadas com tampão T1, e adicionadas à coluna previamente lavada com o mesmo tampão. Uma vez que a coluna foi mantida acoplada a um magneto, apenas as células $C D 34^{+}$, ligadas às microbeads permaneceram retidas na coluna. Essas células foram lavadas com $\mathrm{T} 1$ e retiradas da coluna com o auxílio de um êmbolo para um novo tubo. Esta etapa foi repetida, ou seja, as células passaram por duas colunas de seleção para aumentar a pureza das células CD34+. Após a separação, o número e a viabilidade das células CD34+ foram obtidos em câmara de Neubauer utilizando Azul de Tripan (Trypan Blue).

\subsection{Caracterização imunofenotípica de células-tronco hematopoéticas humanas}

A imunofenotipagem de células $\mathrm{CD} 4^{+}$por citometria de fluxo foi baseado no protocolo recomendado pela ISHAGE Sociedade Internacional de Hematoterapia e Engenharia de Enxerto (International Society for Hematotherapy and Graft Engineering). Este protocolo permite, além da avaliação do tamanho e complexidade celular, seleção da subpopulação de células $\mathrm{CD} 4^{+}$a partir da população total de leucócitos, marcados como anticorpo monoclonal anti-CD45 (células CD45+). ${ }^{(120-}$ 123)

Os anticorpos monoclonais utilizados foram: Lineage (CD3, CD14, CD16, CD19, CD20, CD56) - FITC, CD34-PE-Cy7 (clone: 8G12) e CD117-APC (clone: 104D2) (BD Pharmingen, San Diego, CA), CD38-PE (clone: T16) e CD45 PerCP-Cy5.5 (clone: J33) (Beckman Coulter, Marseille, France). Além disso, foram utilizadas células não marcadas para controle de fluorescência e também, controles para populações CD38, CD34 e CD117 através da técnica de FMO (Fluorescence Minus One), o painel de anticorpos de interesse e controles está disponível na tabela 2. 
Após a separação magnética por afinidade das CTHs, as células foram marcadas com anticorpos monoclonais de interesse acima citados, incubadas em temperatura ambiente protegidas da luz por 30 minutos. Após esse período, as células foram lavadas com $\mathrm{T} 2$, centrifugadas a $500 \mathrm{~g}$, por 5 minutos a $22^{\circ} \mathrm{C}$, ressuspendidas em $100 \mu \mathrm{L}$ de solução tampão T2 e adquiridas em citômetro de fluxo FACS Fortessa - LSR II (BD Biosciences, San Jose, CA), foram por tubo.

Os dados obtidos foram analisados no software FLOWJO (TreeStar, Ashland, OR).

Tabela 2. Painel utilizado na identificação e caracterização das células-tronco hematopoéticas

\begin{tabular}{lccccc}
\hline Fluorocromos & $\begin{array}{c}\text { Células não } \\
\text { marcadas }\end{array}$ & $\begin{array}{c}\text { Marcação de } \\
\text { interesse }\end{array}$ & FMO 1 & FMO 2 & FMO 3 \\
\hline FITC & ---- & Lineage & Lineage & Lineage & Lineage \\
PE & ---- & CD38 & CD38 & ---- & CD38 \\
PC5 & ---- & CD45 & CD45 & CD45 & CD45 \\
PE-Cy7 & ---- & CD34 & CD34 & CD34 & ---- \\
APC & ---- & CD117 & ---- & CD117 & CD117 \\
\hline
\end{tabular}

\subsection{Caracterização das células-tronco mesenquimais por citometria de fluxo}

As CTMs foram obtidas através de filtros descartáveis de MO, onde os mesmos foram lavados com meio Mc1, seguindo de separação da fração mononuclear por gradiente de densidade Ficoll-Paque por centrifugação a $500 \mathrm{~g}$ por 30 minutos, a $22^{\circ} \mathrm{C}$ e colocadas imediatamente em cultura para adesão e expansão das CTMs. As CTMs após a $4^{\underline{a}}$ passagem em cultura foram retiradas do frasco de cultura, centrifugadas e ressuspendidas em T2. Em seguida foram incubadas protegidas da luz por 30 minutos à temperatura ambiente, conforme tabela 3, CD34-PE (clone: My10), CD105-PE-CF594 (clone: 266), CD29-APC (clone: MAR04), CD106-FITC (clone: 5110C9), CD73-PE (clone:AD2), CD90-PE-Cy7 (clone: SE10), CD14-Alexa 700 (clone: M5E2), CD45-V500 (clone:H130), CD31-V450 (clone: WM59), (BD Pharmingen - San Diego - CA), CD44-PerCPCy5 (clone: G44-26), HLA-DR-APC-H7 (clone:G46-6) (BD Biosciences - San Jose - CA) e o controle realizado por FMO.

Posteriormente, as células foram lavadas com T2 e centrifugadas a $500 \mathrm{~g}$ por 5 minutos, a $22^{\circ} \mathrm{C}$ e ressuspendido em $200 \mu \mathrm{L}$ da solução T2. A aquisição das amostras foi realizada no citômetro de fluxo FACS Fortessa - LSR II (BD Biosciences - 
San Jose - CA) e foram adquiridos 10.000 eventos por tubo. A análise dos dados foi realizada utilizando o software FLOWJO (TreeStar, Ashland, OR).

Tabela 3. Painel utilizado na identificação e caracterização das células-tronco mesenquimais

\begin{tabular}{lccccc}
\hline Fluorocromos & Tubo 1 & Tubo2 & FMO1 & FMO2 & $\begin{array}{c}\text { Células não } \\
\text { marcadas }\end{array}$ \\
\hline PE & CD73 & CD34 & CD34 & CD34 & ---- \\
FITC & CD106 & CD19 & CD19 & CD19 & ---- \\
APC & CD29 & CD29 & CD29 & CD29 & ---- \\
PE-CF594 & CD105 & CD105 & CD105 & CD105 & ---- \\
PerCP-Cy5.5 & CD44 & CD44 & CD44 & CD44 & ---- \\
PE-Cy7 & CD90 & CD90 & CD90 & CD90 & ---- \\
V450 & CD31 & CD31 & CD31 & CD31 & ---- \\
Alexa 700 & CD14 & CD14 & CD14 & ----- & --- \\
V500 & CD45 & CD45 & CD45 & CD45 & ---- \\
APC-H7 & HLA-DR & HLA-DR & ---- & HLA-DR & ---- \\
\hline
\end{tabular}

\subsection{Diferenciação das células-tronco mesenquimais em 3 linhagens mesodérmicas}

\subsubsection{Protocolo de diferenciação adipogênica}

Para a diferenciação em adipócitos, o meio de cultura Mc4 foi modificado pelo meio de diferenciação adipogênica composto por alpha-MEM (Gibco, Carlsbad, CA) e suplementado com 10\% de SFB, 1\% de antibiótico-antimicótico, $1 \mu \mathrm{M}$ dexametasona (Sigma, St Louis, MO), 100 $\mathrm{g} / \mathrm{mL}$ de isobutil-metil-xantina (IBMX -Sigma, St Louis, MO) $10 \mu \mathrm{g} / \mathrm{mL}$ de insulina (Sigma, St Louis, MO) e 100 $\mu \mathrm{M}$ de indometacina (IDT - Sigma, St Louis, MO). O meio de diferenciação adipogênica foi adicionado à cultura e trocado em dias alternados durante 21 dias. Após esse período, a diferenciação foi evidenciada pelo o corante oil-red. Após o cultivo por 21 dias, as células foram fixadas com 4\% paraformaldeído (Sigma, St Louis, MO) por 30 minutos, lavadas com DPBS e desidratadas com $60 \%$ isopropanol por 2-5 minutos. Em seguida, as células foram incubadas por 15 minutos com a solução $0,5 \%$ oil red (Sigma, St Louis, MO) diluída em isopropanol. Em seguida, toda a solução foi removida e as células coradas foram lavadas 4 vezes com água deionizada. A diferenciação adipogênica foi evidenciada pela coloração com oil red, a qual cora as gotas lipídicas formadas no interior da célula em vermelho e na sequência foram analisadas e registradas por microscopia óptica. 


\subsubsection{Protocolo de diferenciação e de evidenciação da diferenciação osteogênica}

Para a diferenciação em osteoblastos, o meio de cultura Mc4 foi substituído pelo meio de diferenciação osteogênica composto por alpha-MEM e suplementado com $10 \%$ de SFB, $1 \%$ de antibiótico-antimicótico, $1 \mu \mathrm{M}$ dexametasona (Sigma, St Louis, MO), $2 \mu \mathrm{g} / \mathrm{mL}$ de ácido ascórbico (Sigma, St Louis, MO) e $10 \mu \mathrm{M}$ de beta-glycerol-fosfato (Sigma, St Louis, MO). O meio de diferenciação osteogênica foi adicionado à cultura e trocado em dias alternados durante 21 dias. Após esse período a diferenciação foi evidenciada com o corante alizarin-red. Logo após os 21 dias de diferenciação, as células foram lavadas com DPBS e fixadas com $4 \%$ paraformaldeído por 30 minutos e lavadas com água destilada. Em seguida, as células foram incubadas por 1 hora com o corante $1 \%$ alizarin red $(2 \mathrm{~g}$ alizarin red diluídos em $100 \mathrm{~mL}$ de água destilada, pH 4.2) (Sigma, St Louis, MO), após esse período, a solução foi removida e cada poço foi lavado duas vezes com água destilada. A diferenciação osteogênica foi evidenciada pela coloração alizarin red, a qual cora os depósitos de cálcio em vermelho e na sequência foram analisadas e registradas por microscopia óptica.

\subsubsection{Protocolo de diferenciação e de evidenciação da diferenciação condrogênica}

Para a diferenciação em condrócitos, o meio de cultura Mc4 foi substituído pelo meio de diferenciação condrogênica composto por alpha-MEM e suplementado com $10 \%$ de SFB, $1 \mu \mathrm{g} / \mathrm{mL}$ de ácido ascórbico e $10 \mathrm{ng} / \mathrm{mL}$ de Fator de crescimento transformador $-\beta$ (TGF- $\beta$ transforming growth factor beta) (Sigma, St Louis, MO). O meio de diferenciação condrogênica foi adicionado à cultura e trocado em dias alternados durante 21 dias. Após esse período, a diferenciação foi evidenciada com o corante toluidine blue. Após os 21 dias de diferenciação, os poços foram lavados e as células fixadas com a seguinte sequência: $70 \%$ etanol, $90 \%$ etanol e etanol absoluto, por 1 minuto cada lavagem. As células foram incubadas por 10-15 minutos com o corante azul de toluidina ( $1 \mathrm{~g}$ toluidine-blue, $1 \mathrm{~g}$ de borato de sódio diluídos em $100 \mathrm{~mL}$ de água destilada) (Sigma, St Louis, MO). A diferenciação condrogênica foi evidenciada pela coloração toluidine blue no qual cora a matriz rica em proteoglicanos em azul e na sequência foi analisada e registrada por microscopia óptica. 


\subsection{Cultivo de células-tronco hematopoéticas com ou sem tratamento de CXCL12}

As CTHs selecionadas por separação magnética de afinidade foram cultivadas em placas de 6 poços, em duplicata, na densidade de $5 \times 10^{4} \mathrm{com}$ o meio de cultura Mc3 a $37^{\circ} \mathrm{C}$ com $5 \%$ de $\mathrm{CO}_{2}$, na presença ou ausência da quimiocina CXCL12a/SDF-1a (5ng/mL) (R\&D Systems, Minneapolis, MN). A mesma concentração da quimiocina foi novamente adicionada nos poços com tratamento nos dias 2 e 6 de cultivo.

As análises de imunofenotipagem foram realizadas no dia 0 (imediatamente após a obtenção celular), no $3^{\circ}$ e $7^{\circ}$ dia de cultura. No $7^{\circ}$ dia também foram realizadas análise de expressão proteica da $\beta$-catenina e expressão de gênica.

\subsection{Extração de RNA}

O isolamento do RNA foi realizado utilizando-se o kit RNeasy ${ }^{\circledR}$ Mini Kit (Qiagen, Alemanha) de acordo com as instruções descritas pelo fabricante. Após sete dias de cultura, as células com ou sem tratamento de CXCL12 foram lavadas com PBS (1x), transferidas para um tubo contendo solução tampão RLT e $2 \beta$ - mercaptoetanol. As células foram forçadas à lise celular, através de 5 homogeneizações com seringa e agulha $(0,9 \mathrm{~mm}$ de diâmetro). Em seguida, acrescentou-se etanol à amostra lisada e transferido para a mini coluna do kit de extração de RNA, a fim de ligar o RNA total à membrana. A coluna foi tratada com DNase (Qiagen, Alemanha) por 15 minutos e lavada para remoção de contaminantes. Após, o RNA foi eluido em água livre de RNase (Qiagen, Alemanha).

A quantificação do RNA foi obtida por espectrofotometria, a leitura foi expressa em $\mu \mathrm{g} / \mu \mathrm{L}$ e utilizando-se o equipamento Nanovue (GE Healthcare,Chicago, IL). Para descartar a presença de contaminantes foram utilizadas as amostras que apresentaram a relação de absorbâncias (A260/280nm e A260/230nm) entre 1,8 e 2,0. 


\subsection{Síntese de cDNA - reação de transcrição reversa}

O cDNA (fita complementar de DNA) foi produzido a partir de $1 \mu \mathrm{g}$ de RNA total utilizando-se o kit Quantitec Reverse Transcription (Qiagen, Alemanha), seguindo protocolo de acordo com as recomendações do fabricante.

A reação ocorreu no termociclador seguindo duas etapas. A primeira etapa consistiu na eliminação de DNA genômico que eventualmente pudesse estar presente na amostra. Nessa etapa utilizou-se gDNase, que junto com o RNA e água foram então aquecidos à $42^{\circ} \mathrm{C}$ durante 2 minutos e em seguida resfriados à $4{ }^{\circ} \mathrm{C}$. $\mathrm{Na}$ sequência, iniciou-se a transcrição do cDNA e para isso foram adicionados a enzima RT transcriptase reversa (Reverse Transcription) Quantiscript, o RT Primer Mix e o tampão RT. A reação foi realizada a $42^{\circ} \mathrm{C}$ durante 15 minutos, em seguida a $95^{\circ} \mathrm{C}$ durante 3 minutos para inativar a atividade da enzima $\mathrm{RT}$, seguido de armazenamento a $-20^{\circ} \mathrm{C}$.

\subsection{Cocultivo de células-tronco mesenquimais e células-tronco hematopoéticas}

Os ensaios de cocultivo e a extração de RNA das CTHs foram realizados previamente durante dissertação de mestrado desenvolvida no grupo. ${ }^{(118)}$ As CTHs selecionadas por separação magnética de afinidade foram cocultivadas com CTMs de indivíduos de diferentes faixas etárias (entre 22 e 48 anos), em uma placa de 24 poços, as CTMs foram plaqueadas na densidade de $2 \times 10^{4}$ com o meio de cultura Mc1 e foram cultivadas a $37^{\circ} \mathrm{C}$ com $5 \%$ de $\mathrm{CO}_{2}$ em incubadora umidificada até atingirem $70 \%$ de confluência. Em seguida, as CTHs foram semeadas na densidade de $1 \times 10^{4}$ por poço e o meio de cultura foi substituído pelo Mc3, acima descrito. As CTHs foram coletadas no $3^{\circ}$ e $7^{\circ}$ dia para realização da análise imunofenotípica por citometria de fluxo e ao $7^{\circ}$ dia, foram extraídos os RNAs das CTHs e armazenados a $-80^{\circ} \mathrm{C}$ para posterior análise de expressão gênica.

\subsection{Síntese de cDNA - amplificação completa do transcriptoma}

Conforme descrito acima, foi utilizado o RNA que encontrava-se armazenado proveniente das CTHs mantidas em cocultivo com as CTMs. O cDNA foi 
produzido a partir de 10ng de RNA total utilizando-se o kit QuantiTect $^{\circledR}$ Whole Transcriptome (Qiagen, Alemanha), seguindo protocolo de acordo com as recomendações do fabricante.

A reação ocorreu no termociclador seguindo três etapas. A primeira etapa consistiu na transcrição reversa do cDNA utilizando enzima T-Script e tampão "TScript Buffer", contendo random primers e oligo-dT mantidos por $30 \mathrm{~min}$ a $37^{\circ} \mathrm{C}$ e $5 \mathrm{~min}$ a $95^{\circ} \mathrm{C}$. Após, realizou-se a etapa de ligação, onde o cDNA sintetizado é ligado por meio de uma mistura de ligação de alta eficiência (Enzima de Ligação 1, Enzima de Ligação 2, Reagente de Ligação e Tampão de Ligação) e mantidos por 2 horas a $22^{\circ} \mathrm{C}$. Por fim realizamos a etapa de amplificação total do transcriptoma, uma vez que o cDNA ligado foi amplificado em uma reação isotérmica com duração de 2 horas a $30^{\circ} \mathrm{C}$ utilizando uma mistura de amplificação (REPLI-g Midi DNA Polymerase e REPLI-g Midi Reaction Buffer), e o produto final foi submetido a $95^{\circ} \mathrm{C}$ por 5 min para inativação enzimática.

\subsection{Desenho dos oligonucleotídeos iniciadores/primers}

Os oligonucleotídeos utilizados na Reação em cadeia da polimerase (PCR - Polymerase Chain Reaction) foram desenhados a partir do aplicativo Integrated DNA Technologies (https://www.idtdna.com) com base nas sequências de RNAm obtidas através do banco de dados GenBank e sintetizados pela empresa Invitrogen. A sequência completa das fitas sense e antisense e eficiência dos primers podem ser visualizadas na tabela 4.

Tabela 4. Padronização e eficiência dos primers

\begin{tabular}{|c|c|c|c|}
\hline Primer & Sequência $5^{\prime} \rightarrow 3^{\prime}$ & Concentração & Eficiência \\
\hline$\overline{G A P D H}$ & $\begin{array}{c}\text { Sense: GAGAAGGCTGGGGCTCA } \\
\text { Antisense: GTCCTTCCACGATACCAAA }\end{array}$ & $400 \mathrm{nM}$ & $98 \%$ / R2: 0,99 \\
\hline RPL13a & $\begin{array}{l}\text { Sense: TTGAGGACCTCTGTGTATTTGTCAA } \\
\text { Antisense: CCTGGAGGAGAAGAGGAAAGAGA }\end{array}$ & 400nM & $98 \%$ / R2: 0,99 \\
\hline SOX2 & $\begin{array}{c}\text { Sense: TGGGAGGGGTGCAAAAGAGG } \\
\text { Antisense: GAGTGTGGATGGGATTGGTG }\end{array}$ & 250nM & $100 \%$ / R2: 0,99 \\
\hline POU5F1 & $\begin{array}{l}\text { Sense: AGAAGTGGGTGGAGGAAGCTGACAA } \\
\text { Antisense: TGGGTTTCGGGCACTGCAGG }\end{array}$ & 800nM & $85 \%$ / R2: 0,99 \\
\hline NANOG & $\begin{array}{c}\text { Sense: CCTATGCCTGTGATTTGTGG } \\
\text { Antisense: CTGGGACCTTGTCTTCCTTT }\end{array}$ & $250 \mathrm{nM}$ & $112 \%$ / R2: 0,99 \\
\hline KLF4 & $\begin{array}{l}\text { Sense: ACCTACACAAAGAGTTCCCATC } \\
\text { AntiSense: ATCTGAGCGGGCGAATTT }\end{array}$ & 400nM & $113 \%$ / R2: 0,99 \\
\hline$\beta$-Catenina & $\begin{array}{c}\text { Sense: TTACGAAAAACTACTGTGGACCA } \\
\text { Antisense: AAAGATTCCTGAGAGTCCAAAGA }\end{array}$ & $400 \mathrm{nM}$ & $90 \%$ / R2: 0,99 \\
\hline
\end{tabular}




\begin{tabular}{|c|c|c|c|}
\hline IKZF1 & $\begin{array}{l}\text { Sense: GGCCAGTAATGTTAAAGTAGAGA } \\
\text { Antisense: GGCATCAAGCATTCGTAAATC }\end{array}$ & $200 \mathrm{nM}$ & 102\% / R2: 0,98 \\
\hline GATA2 & $\begin{array}{c}\text { Sense: AGAACCGACCACTCATCA } \\
\text { Antisense: TGGTTGTCGTCTGACAATTT }\end{array}$ & $200 \mathrm{nM}$ & 109\% / R2:0,99 \\
\hline GATA3 & $\begin{array}{l}\text { Sense: TCATTAAGCCCAAGCGAAG } \\
\text { Antisense: CATTCCTCCTCCAGAGTGT }\end{array}$ & $200 \mathrm{nM}$ & $90 \%$ / R2: 0,99 \\
\hline PU.1 & $\begin{array}{l}\text { Sense: GAGCCATAGCGACCATTAC } \\
\text { Antisense: GCTCCGTGAAGTTGTTCT }\end{array}$ & $200 \mathrm{nM}$ & 107\% / R2: 0,99 \\
\hline Notch1 & $\begin{array}{l}\text { Sense: AGGCAATCCGAGGACTAT } \\
\text { Antisense: AGAACGCACTCGTTGATG }\end{array}$ & $200 \mathrm{nM}$ & 108\% / R2: 0,99 \\
\hline HBOX4 & $\begin{array}{c}\text { Sense: CTGGATGCGCAAAGTTCA } \\
\text { Antisense: TTCCTTCTCCAGCTCCAA }\end{array}$ & $200 \mathrm{nM}$ & 98\% / R2: 0,99 \\
\hline CXCL12 & $\begin{array}{c}\text { Sense: TGCCGATTCTTCGAAAGC } \\
\text { Antisense: CTACAATCTGAAGGGCACAG }\end{array}$ & $200 \mathrm{nM}$ & 95\% / R2: 0,99 \\
\hline
\end{tabular}

\subsection{Realização dos ensaios de reação em cadeia da polimerase em tempo real}

As reações de qRT-PCR foram realizadas no equipamento ABlprism 7500 empregando-se o kit SyberGreen Fast (Qiagen, Alemanha), seguindo as instruções do fabricante. Resumidamente, foi feita uma mistura contendo cDNA diluído 8 vezes (3,0 $\mathrm{LL}$ - 20ng), oligonucleotídeo sense e antisense (cujas concentrações variaram de acordo com a padronização dos oligonucleotídeos descrita na Tabela 4) e de SyberGreen. A ciclagem determinada pelo fabricante ocorreu de acordo com as seguintes etapas: 5 minutos a $95^{\circ} \mathrm{C}$ seguidos de 40 ciclos de 10 segundos a $95^{\circ} \mathrm{C}$ (para desnaturação do DNA), 30 segundos a $60^{\circ} \mathrm{C}$ (para anelamento dos oligonucleotídeos/extensão da nova fita de DNA e detecção da fluorescência), finalizando o ciclo com etapa da obtenção da curva de Melting. As reações foram realizadas para determinar a expressão dos genes constitutivos ou controle endógeno, RPL13a e GAPDH e dos genes de interesse do estudo: SOX2, POU5F1, NANOG, KLF4, B-Catenina, IKZF1, GATA2, GATA3, PU.1, NOTCH1 e HOXB4. Para análise dos resultados dos valores de $\mathrm{Ct}$ "Cycle threshold" foi utilizado o Software 7500 versão v2.0.6.

\subsection{Padronização dos primers e curvas de eficiência - Reação em cadeia da polimerase em tempo real}

Para a curva de eficiência as amostras de cDNA foram diluídas em série $(1: 4 ; 1: 8 ; 1: 16 ; 1: 32 ; 1: 64)$ todas em triplicatas, e em seguida, foram conduzidos os ensaios de qRT-PCR nos quais, a quantidade de reagentes e a ciclagem utilizada no 
equipamento para a reação foi a mesma utilizada conforme protocolo descrito acima Foram consideradas eficientes as curvas que apresentaram valores próximos a $100 \% .{ }^{(124,125)}$ As curvas dos genes de controle endógeno estão demonstradas como exemplo nas figuras 9 e 10.
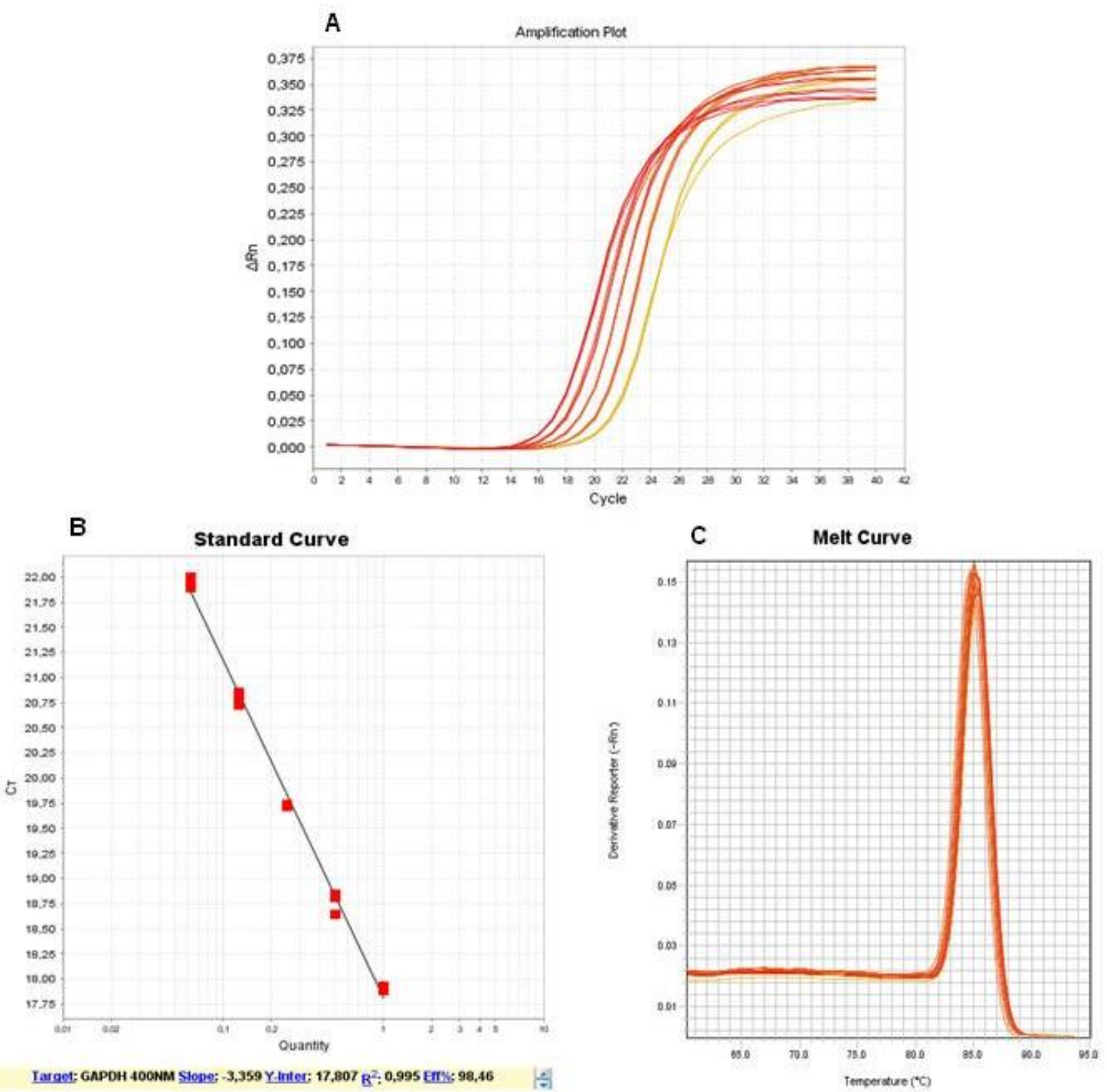

(A) curva de amplificação; (B) Curva padrão, demonstrados os valores de eficiência e $R^{2}$; (C). curva de Melting, dissociação de um único produto.

Figura 9. Curva padrão, de eficiência e Melting mostrando a eficiência do primer GAPDH, utilizado como controle endógeno 

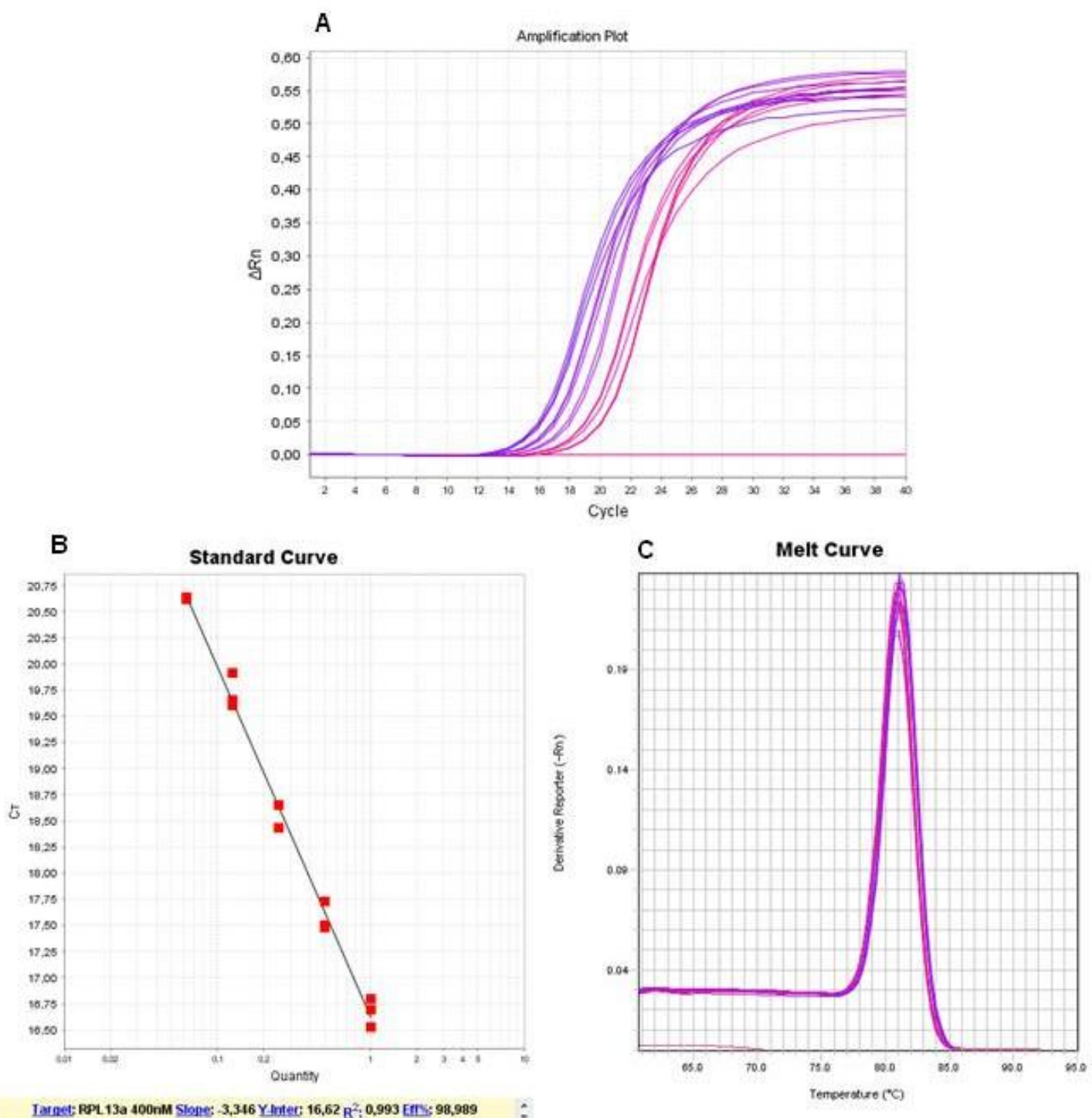

(A) curva de amplificação; (B) Curva padrão, demonstrados os valores de eficiência e $R^{2}$; (C). curva de Melting, dissociação de um único produto.

Figura 10. Curva padrão, de eficiência e Melting mostrando a eficiência do primer RPL13a, utilizado como controle endógeno

\subsection{Ensaio de confocal - $\beta$-catenina}

Após sete dias de cultura, as CTHs cultivadas na presença ou ausência de CXCL12 foram lavadas com PBS 1x, fixadas com paraformaldeído a $4 \%$ e incubadas entre $2^{\circ} \mathrm{C}$ a $8^{\circ} \mathrm{C}$ por 30 minutos. As células foram centrifugadas em lâminas de vidro, utilizando a Citocentrífuga CT2000, rotação de 250g por 3 minutos. Após confecção da lâmina a marcação ocorreu com anticorpo primário de camundongo antihumano Beta-Catenina, (Clone: $\beta$-catenina-1, imunógeno: proteína de fusão glutationa S-transferase $\beta$-catenina $C$-terminal recombinante), no formato já diluído (Dako - 
Dinamarca) (overnight a $37^{\circ} \mathrm{C}$ ) e secundário de coelho anti-camundongo - FITC (1:200) (Invitrogen, Carlsbad, CA) $\left(2 \mathrm{~h}\right.$ a $\left.37^{\circ} \mathrm{C}\right)$ após 1 hora de bloqueio dos sítios inespecíficos com solução de PBS 1X contendo 1\% de albumina humana e de permeabilização com solução de PBS $1 \mathrm{X}$ contendo Triton $0.04 \%$ por 10 minutos à temperatura ambiente. Foi considerado controle negativo as células marcadas somente com anticorpo secundário para certificar a ausência de marcações inespecíficas. O núcleo das células foi marcado com DAPI (4',6-diamidino-2-phenylindole), as fluorescências foram analisadas em microscópio confocal Zeiss LSM 710, e as imagens foram geradas e analisadas no software Zeiss Zen 2.3 lite.

\subsection{Padronização do ensaio de silenciamento de mRNA e proteína (CXCL12)}

\subsubsection{Ensaio de transfecção em células-tronco mesenquimais humanas - siRNA}

Para os ensaios de inibição da expressão do mRNA da quimiocina CXCL12, utilizamos o RNA pequeno de silenciamento comercial (siRNA CXCL12 ID8667), cujo a sequência de nucleotídeos sense GGAGUACCUGGAGAAAGCUtt e antisense AGCUUUCUCCAGGUACUCCtg (Ambion Thermofisher ${ }^{\circledR}$ ). As células-tronco mesenquimais humanas entre as passagens 4 e 7 foram submetidos à transfecção reversa com siRNA CXCL12 acima mencionado, bem como com um RNA pequeno de silenciamento controle negativo comercial (Silencer ${ }^{\circledR}$ Negative Control 2 siRNA - Ambion Thermofisher $^{\circledR}$ ) e somente com adição do agente de transfecção siPORT ${ }^{\circledR} \mathrm{NeoFx}^{\mathrm{TM}}$, seguindo recomendações do fabricante. Neste tipo transfecção (reversa) as células são homogeneizadas com o complexo de transfecção (siRNA e agente de transfecção) anteriormente adesão à placa (Figura 11). 


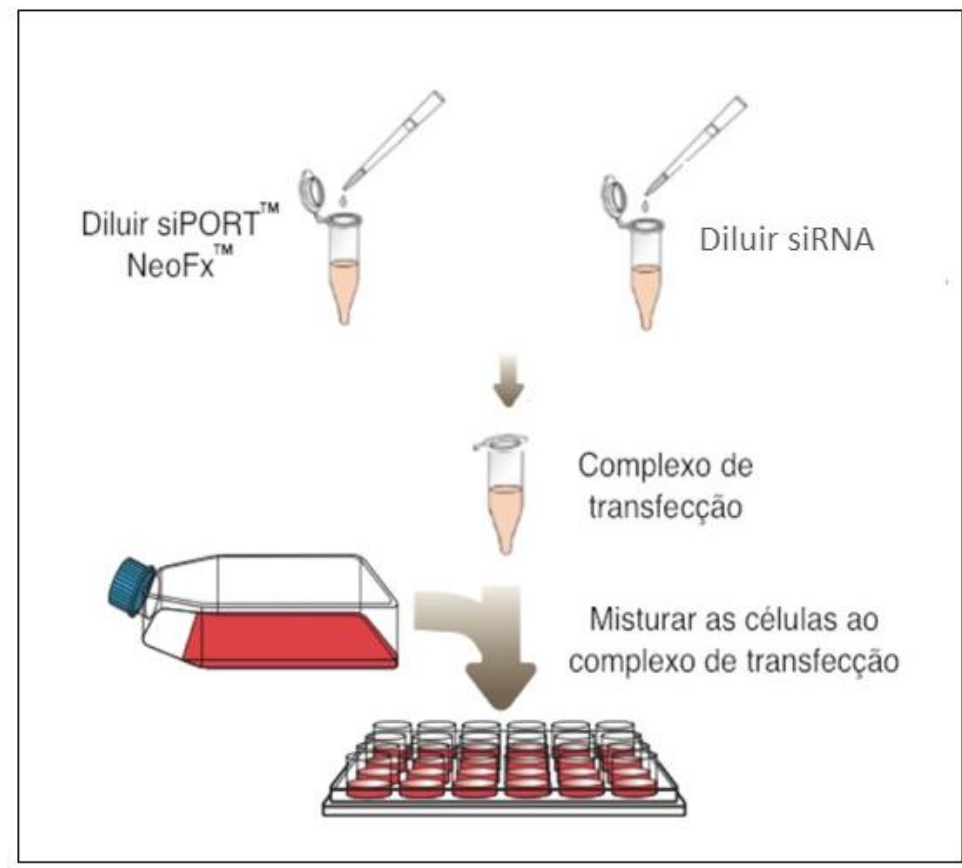

As células se encontravam em suspensão no momento do experimento, permitindo maior exposição ao complexo de transfecção (agente de transfecção e ácido nucleico). Esse método contribui para a eficiência da transfecção. Fonte: Traduzido e adaptado de siPORT TM NeoFX ${ }^{\text {TM }}$ Transfection Agent. Waltham: Thermo Fisher Scientific; 2011 [cited 2020 Sep 23]. Available from: https://assets.thermofisher.com/TFS-

Assets/LSG/manuals/cms_056634.pdf.

Figura 11. Esquema da trānsfecção reversa

Conforme sugestão do kit, foi utilizada a concentração de 30nM de siRNA no ensaio de transfecção. Para o agente de transfecção, siPORT ${ }^{\circledR} \mathrm{NeoFx}^{\mathrm{TM}}$, foram testadas as concentrações recomendadas pelo kit, em placas de 24 poços, em cada poço foi utilizado $1 \mu \mathrm{L}$ de $\operatorname{siPOR}{ }^{\circledR} N e o F x^{\mathrm{TM}}$ para $25 \mu \mathrm{L}$ de opti-MEM observando a morfologia e viabilidade celular. Também foram testadas concentrações celulares variáveis: $2 \times 10^{4}$ e $4 \times 10^{4}$ células em placa de 24 poços. Além disso, para o mesmo kit foram realizados testes de transfecção direta (adicionando o complexo de transfecção diretamente nas células aderidas) nas mesmas condições de concentração de agente de transfecção e células. A expressão gênica em 48 horas, 72 horas e 96 horas após a transfecção foi avaliada empregando-se a técnica de PCR em tempo real, os procedimentos de extração de RNA e PCR estão descritas nos itens 2.10 e 2.15, respectivamente. 


\subsubsection{Detecção da quimiocina CXCL12}

\subsubsection{Citometria de Fluxo - Proteína intracelular}

Para a detecção intracelular da quimiocina CXCL-12/SDF-1 das células-tronco mesenquimais após o ensaio de silenciamento, foi empregada a técnica de citometria de fluxo. Após 72h, 96h e 120h horas do início da transfecção, as CTMs controle, sem nenhum tipo de tratamento, as que foram transfectadas com siRNACXCL12, siRNA controle negativo e, também tratadas somente com agente de transfecção foram incubadas com $5 \mu \mathrm{L}$ de inibidor de transporte de proteína do retículo endoplasmático para o complexo de Golgi (BD Golgi Plug - BD Biosciences, San Jose, CA) por 12 horas. Após este período de incubação, as células foram tripsinizadas e ressuspendidas em $1 \mathrm{~mL}, 200 \mu \mathrm{L}$ foram utilizados como controle negativo e o restante seguiu para o processo de marcação intracelular para quimiocina CXCL12, de acordo com o protocolo de marcação intracelular de citocinas do fabricante. Brevemente, foi adicionado $1 \mathrm{~mL}$ de solução BD FACS ${ }^{\mathrm{TM}}$ Lysing (BD Biosciences, San Jose, CA) nas células as quais foram incubadas por 10 minutos a temperatura ambiente e protegidas da luz. Em seguida, as células foram lavadas com tampão T2, centrifugadas 5 minutos a $500 \mathrm{~g}$ e ressuspendidas em $1 \mathrm{~mL}$ de solução FACS permeabilizante BD FACS ${ }^{\mathrm{TM}}$ Permeabilizing solution 2 (BD Biosciences, San Jose, CA), incubadas por 10 minutos a temperatura ambiente e protegidas da luz. Após o período de incubação, as células foram lavadas com tampão T2 e novamente centrifugadas por 5 minutos a $500 \mathrm{~g}$. Após a permeabilização, as células foram marcadas com anticorpo intracelular para detecção da quimiocina CXCL12 (APC-Clone 790, R\&D Systems, Minneapolis, MN). Após a marcação, as células foram lavadas com tampão T2 5 minutos a $500 \mathrm{~g}$ e ressuspendidas em $200 \mu \mathrm{L}$ de tampão T2. Por fim, as células foram adquiridas em citômetro de fluxo FACS Fortessa - LSR II (BD Biosciences, San Jose, CA). Os dados obtidos foram analisados no software FLOWJO (TreeStar, Ashland, OR).

\subsubsection{Ensaio de Imunoabsorção enzimática - Proteína secretada}

Para a detecção da quimiocina CXCL-12 no sobrenadante do cultivo 
das células-tronco mesenquimais após $72 \mathrm{~h}$ e $96 \mathrm{~h}$ do ensaio de transfecção, foi empregada o ensaio de Imunoabsorção enzimática (ELISA - enzyme-linked immunosorbent assay), para a qual foi utilizado o Kit Human CXCL-12/SDF1a (R\&D Systems, Minneapolis, MN). A técnica foi realizada com as amostras em duplicata da seguinte maneira; foram adicionados à microplaca 100 $\mu \mathrm{L}$ do diluente RD1-55, logo em seguida adicionamos $100 \mu \mathrm{L}$ do sobrenadante do cultivo de células-tronco mesenquimais controle, sem nenhum tipo de tratamento, as que foram transfectadas com siRNACXCL12, siRNA controle negativo e tratadas somente com agente de transfecção. Em seguida, foram incubadas por 2 horas temperatura ambiente sob agitação de 500rpm. Após o período de incubação, cada poço foi lavado 4 vezes com $400 \mu \mathrm{L}$ de Wash Buffer. Posteriormente, foi acrescentado $200 \mu \mathrm{L}$ do conjugado de SDF-1 que permaneceu na placa em agitação de 500rpm por 2 horas, o procedimento de lavagem foi repetido novamente. Acrescentamos $200 \mu \mathrm{L}$ da solução de substrato em cada poço e incubamos por 30 minutos em temperatura ambiente protegido de luz. Foi adicionado $50 \mu \mathrm{L}$ de solução de parada de reação e a quantificação foi realizada pela leitura da absorbância no leitor de ELISA Varioskan LUX (ThermoScientific).

\subsubsection{Clonagem das sequências do RNA pequeno em grampo contra o transcrito codificador de CXCL12 em vetor lentiviral}

Utilizamos vetor lentiviral capaz de carregar as sequências de oligonucleotídeos que serão integrados ao genoma das CTMs, tornando a expressão dos shRNAs permanentes. Para tanto, os oligonucelotídeos utilizados neste estudo foram selecionados através das ferramentas online BLOCK-IT $T^{\mathrm{TM}}$ RNAi Designer (Invitrogen, Carlsbad, CA) e siRNA Wizard ${ }^{\mathrm{TM}}$ (Invitrogen, Carlsbad, CA) (Tabela 5). Os oligos foram sintetizados pela empresa Invitrogen e reconstiuídos para a concentração de $100 \mathrm{pmol} / \mu \mathrm{L}$. 
Tabela 5. Sequências dos oligonucleotídeos correspondentes aos RNA pequeno em grampo (short hairpin RNA) contra o transcrito codificador de CXCL12

\begin{tabular}{lr}
\hline Oligo & Sequência 5' \\
\hline --> 3' \\
shRNA 1 S & TGGGAGTACCTGGAGAAAGCTTTCTCGAGAAAGCTTTCTCCAGGTACTCCCTTTTTTC \\
shRNA 1 A & TCGAGAAAAAAGGGAGTACCTGGAGAAAGCTTTCTCGAGAAAGCTTTCTCCAGGTACTCCCA \\
shRNA 2 S & TGGCATTGACCCGAAGCTAAAGTCTCGAGACTTTAGCTTCGGGTCAATGCCTTTTTTC \\
shRNA 2 A & TCGAGAAAAAAGGCATTGACCCGAAGCTAAAGTCTCGAGACTTTAGCTTCGGGTCAATGCCA \\
shRNA 3 S & TGGAGCCAACGTCAAGCATCTCACTCGAGTGAGATGCTTGACGTTGGCTCCTTTTTTC \\
shRNA 3 A & TCGAGAAAAAAGGAGCCAACGTCAAGCATCTCACTCGAGTGAGATGCTTGACGTTGGCTCCA \\
shRNA 4 S & TGGGCTGAAGAACAACAACAGACCTCGAGGTCTGTTGTTGTTCTTCAGCCCTTTTTTC \\
shRNA 4 A & TCGAGAAAAAAGGGCTGAAGAACAACAACAGACCTCGAGGTCTGTTGTTGTTCTTCAGCCCA \\
Controle S & TGCCTAAGGTTAAGTCGCCCTCGCTCGAGCGAGGGCGACTTAACCTTAGGCTTTTTTC \\
Controle A & TCGAGAAAAAAGCCTAAGGTTAAGTCGCCTCGCTCGAGCGAGGGCGACTTAACCTTAGGCA \\
\hline S: sense; A: antisense. Modificação em 5': Inserido fosfato. Controle: sequência conhecida que não \\
tem como alvo genes em humanos. Vermelho: sequência correspondente ao shRNA. Sublinhado: \\
sequência que forma o loop. Azul: sequência reversa complementar do shRNA seguida de um sinal de \\
término de transcrição. Verde: pontas coesivas para a enzima Xhol.
\end{tabular}

\subsubsection{Anelamento dos oligonucleotídeos}

Cada par de oligonucleotídeos foi anelado em uma reação de $50 \mu \mathrm{L}$ contendo $10 \mu \mathrm{L}$ de oligonucleotídeo sense $10 \mu \mathrm{L}$ de oligonucleotídeo antisense e $5 \mu \mathrm{L}$ de tampão de anelamento (Tris $\mathrm{pH} 7,9400 \mathrm{nM}, \mathrm{NaCl} 500 \mathrm{nM}$ e $\mathrm{MgCl}_{2}$ 10nM). Após o anelamento, essa reação foi inicialmente incubada a $95^{\circ} \mathrm{C}$ por 5 minutos e, em seguida, a temperatura foi diminuída de forma controlada, $0,5^{\circ} \mathrm{C}$ por minuto. Os oligonucleotídeos foram, então, precipitados utilizando 2 volumes de solução de etanol absoluto overnight a $-80^{\circ} \mathrm{C}$. Após esse período, foram lavados com etanol $95 \%$, ressuspensos com $100 \mu \mathrm{L}$ de $\mathrm{H}_{2} \mathrm{O}$ livre de nuclease e quantificados por espectrofotometria utilizando o equipamento Nanodrop (Thermofisher).

\subsubsection{Digestão do vetor pLL3.7}

Para este estudo, utilizamos o vetor pLL3.7 (Figura 12) modificado, onde o promotor U6 de camundongo original foi substituído pelo promotor U6 humano (cordialmente cedido por Dra. Fernanda Mansur). O plasmídeo foi digerido em uma reação de 50 $\mu \mathrm{L}$ contendo $5 \mu \mathrm{L}$ de tampão CutSmart 10x (New England Biolabs - NEB), $1 \mu \mathrm{L}$ da enzima Xhol (Fermentas - Thermo Fisher Scientific), $1 \mu \mathrm{L}$ da enzima Hpal (New England Biolabs - NEB). 


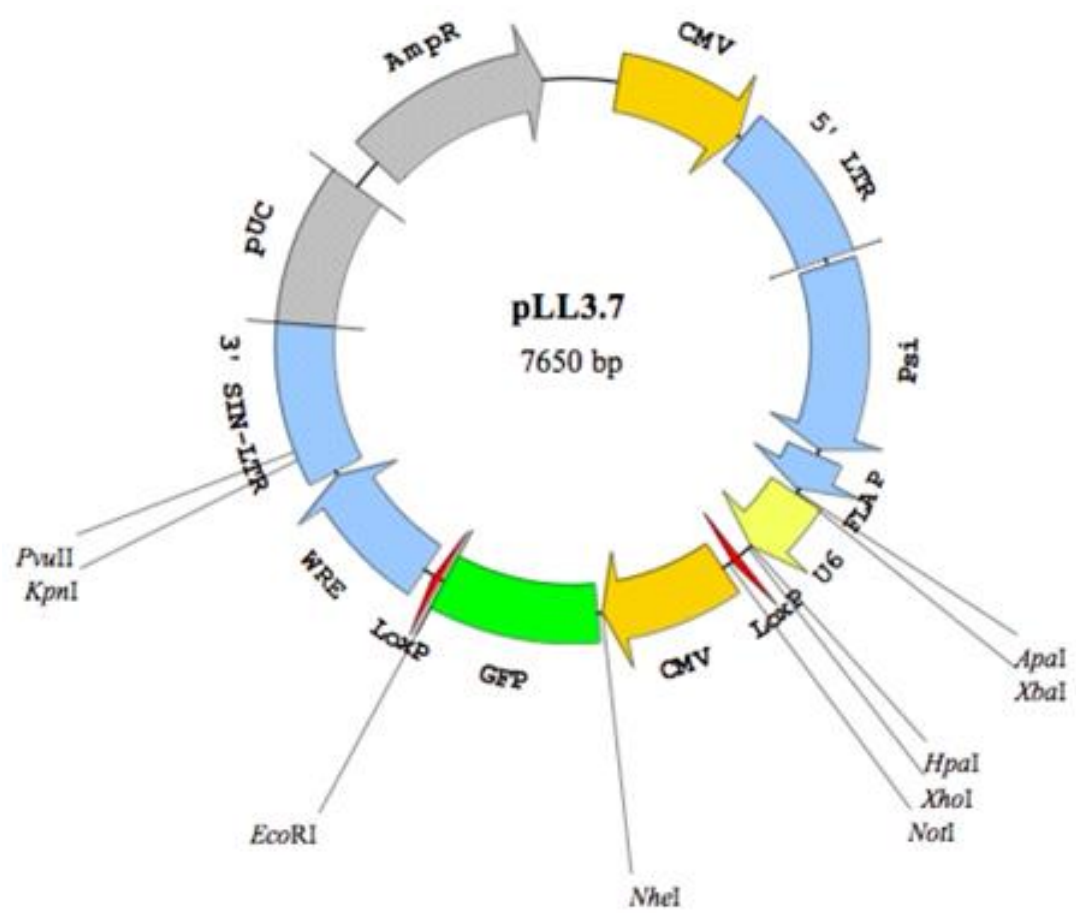

Fonte: Parijs, L. Addgene plasmid, [updated 2020; cited 2020 Sep 23]. Available from: https://www.addgene.org/11795/.

Figura 12. Mapa do plasmídeo utilizado para clonagem dos shRNAs

\subsubsection{Ligação do RNA pequeno em grampo (short hairpin RNA) ao plasmídeo}

Para a reação de ligação entre os shRNAs e o plasmídeo, foram adicionados $4 \mu \mathrm{L}$ de tampão de reação da DNA ligase 5x (Invitrogen, Carlsbad, CA),

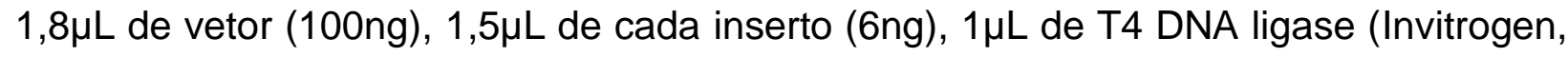
Carlsbad, CA) e 11,7 $\mu \mathrm{L}$ de H20 livre de nuclease. A reação ocorreu no termociclador Veriti (Thermofisher), overnight a $16^{\circ} \mathrm{C}$. Para controle negativo da reação, adicionamos somente o plasmídeo digerido e sem adição de quaisquer shRNA.

\subsubsection{Transformação da reação de ligação em bactérias cálcio competentes}

Em todas as transformações, foram utilizadas bactérias Escherichia coli cálcio competentes da linhagem Stbl3TM (Invitrogen, Carlsbad, CA). Para tanto, alíquotas de $100 \mu \mathrm{L}$ de bactéria competente foram previamente descongeladas e mantidas em gelo e a elas adicionados $10 \mu \mathrm{L}$ da reação de ligação. A transformação ocorreu pelo método de choque térmico, onde as bactérias permaneceram no gelo por 30 minutos e, em seguida, incubadas a $42^{\circ} \mathrm{C}$ por $45 \mathrm{~s}$, sendo colocadas novamente no 
gelo por $1 \mathrm{~min}$. Logo após transformadas, foi adicionado $1 \mathrm{~mL}$ de meio $\mathrm{LB}$ sem antibióticos e as células foram mantidas sob agitação $(200 \mathrm{rpm})$ a $37^{\circ} \mathrm{C}$ por uma hora. Em seguida, a cultura foi plaqueada em placas com meio LB-ágar contendo ampicilina $(100 \mu \mathrm{g} / \mathrm{mL})$ e incubadas a $37^{\circ} \mathrm{C}$ durante 16 horas para seleção de colônias positivas. Nas transformações realizadas, foi utilizado um controle de viabilidade da bactéria, através da transformação paralela de um vetor fechado.

\subsubsection{Confirmação da clonagem por reação em cadeia da polimerase de colônia}

As ligações foram confirmadas por reações de PCR com utilização de oligonucleotídeos específicos que anelam em regiões adjacentes ao sítio de clonagem dos shRNAs (Sequência Sense: CAGTGCAGGGGAAAG; Sequência Anti-sense: CCGCTTAAGCTTGGAACCCT), sintetizados pela empresa Invitrogen.

Os produtos resultantes das amplificações foram avaliados por meio de eletroforese em gel de agarose $1 \%$. A eletroforese foi conduzida em cuba horizontal a 100V em tampão TAE 1X, pelo tempo necessário para separação das bandas. Os géis foram visualizados sob luz UV e fotodocumentados no equipamento ChemiDoc (BioRad). As colônias positivas foram inoculadas em $5 \mathrm{~mL}$ de meio LB contendo ampicilina e incubadas por 16 horas a $37^{\circ} \mathrm{C}$ sob agitação (200rpm). A purificação do plasmídeo foi realizada com o kit QIAprep ${ }^{\circledR}$ Spin Miniprep (Qiagen, Alemanha) conforme orientações do fabricante seguindo o protocolo para uso em microcentrífuga.

\subsubsection{Extração de DNA plasmidial - midiprep}

Após a confirmação da clonagem, as colônias positivas foram inoculadas em $100 \mathrm{~mL}$ de meio LB-líquido adicionado de ampicilina, incubadas sob agitação constante a $37^{\circ} \mathrm{C}$ por $16 \mathrm{~h}$. Decorrido o período, foram centrifugadas a $6.000 \mathrm{x}$ g por 10 minutos. $O$ sobrenadante foi descartado e o precipitado submetido à extração plasmidial com utilização do kit Plasmid Midi Kit (Qiagen, Alemanha) de acordo com as instruções do fabricante. O material extraído foi quantificado em aparelho de especfotrometria Nanodrop (Thermo Scientific ${ }^{\circledR}$ ) e armazenado à $-20^{\circ} \mathrm{C}$. 


\subsubsection{Transfecção das células HEK-293-T - Confecção do lentivírus}

O vetor pLL3.7 gerado contendo as sequências de shRNAs de interesse foi transfectado em células da linhagem HEK- 293T, juntamente com os plasmídeos psPAX2 (contém os genes Gag, Pol, Rev e Tat) e VSV-G (contém a sequência codificadora da glicoproteína $\mathrm{G}$ do envelope), para produção de lentivírus. Um dia antes da transfecção, $3,5 \times 10^{6}$ células foram plaqueadas em placas de $10 \mathrm{~cm}$. Duas a quatro horas antes da transfecção, o meio das células foi substituído por $4 \mathrm{~mL}$ de meio DMEM completo. Para a transfecção, foram adicionados em um tubo $200 \mu \mathrm{L}$ de TE $0,1 \mathrm{x}$ (1 $\mathrm{mM}$ TrisHCl, 0,1 mM EDTA pH 8), 24,3uL de $\mathrm{CaCl}_{2} 2,5 \mathrm{M}, 2,1$ ug do plasmídeo VSVG, 3,5ug de plasmídeo psPAX2 e, por fim, 2,5ug do plasmídeo pLL3.7. Após homogeneização desses reagentes, 200 $\mu \mathrm{L}$ de HBS 2x (42mM Hepes, 274mM NaCl, $10 \mathrm{mM} \mathrm{KCl}, 1,5 \mathrm{mM} \mathrm{Na}_{2} \mathrm{HPO}_{4}, 11 \mathrm{mM}$ sacarose, $\mathrm{pH}$ 7,2) foi adicionado gradualmente por gotejamento. Ao final, a reação foi adicionada à placa contendo as células que foram incubadas por 16 horas. No dia seguinte, o meio foi substituído por $10 \mathrm{~mL}$ de meio Mc4.

Após 48 horas, o sobrenadante da cultura de HEK-293T contendo lentivirus foi coletado e filtrado para eliminação de células mortas e debris. O material foi aliquotado e armazenado em freezer $-80^{\circ} \mathrm{C}$ até o momento da utilização.

Conforme ilustrado na figura 13, as partículas lentivirais são criadas por cotransfecção de uma linhagem de células (Hek-293T) com o plasmídeo de transferência expressando shRNA juntamente com dois plasmídeos auxiliares de empacotamento que codificam as proteínas estruturais e de envelope (psPAX2 e VSVG). As células empacotadoras produzem partículas infecciosas, cujo genoma codifica apenas sequências do plasmídeo de transferência, que podem ser usadas para transduzir as células-alvo, neste caso células-tronco mesenquimais humanas. 


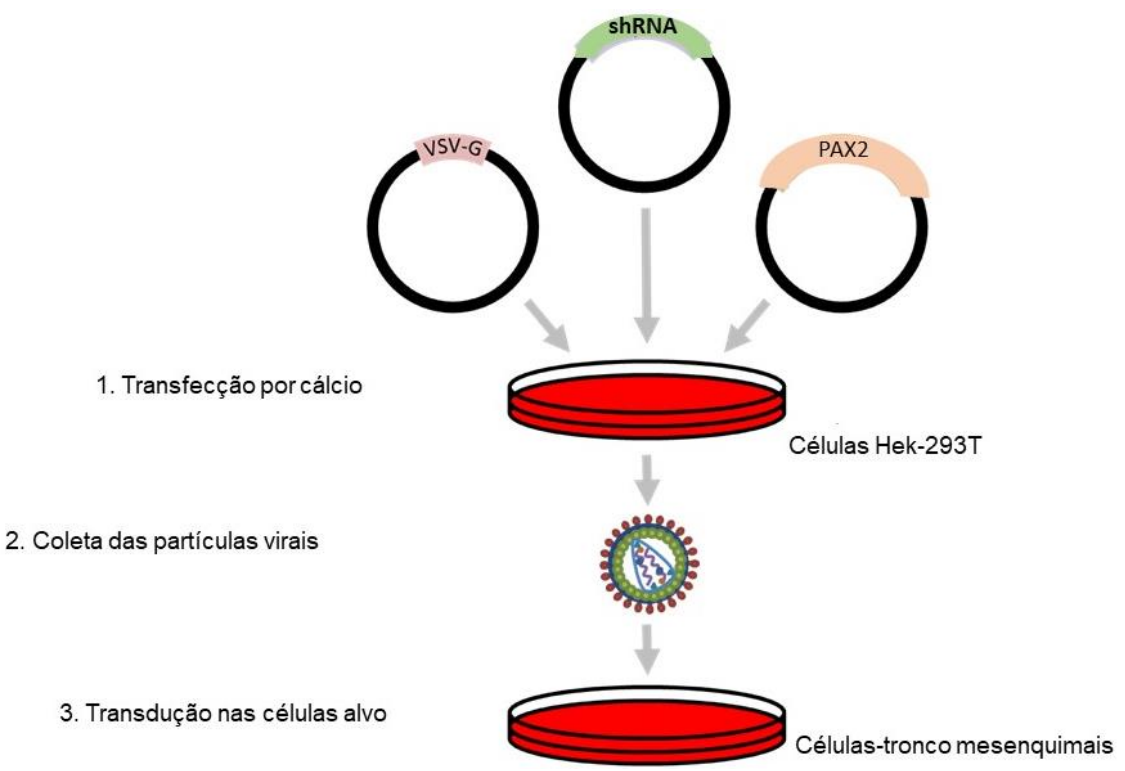

Fonte: Traduzido e adapatado de O'Keefe PE. Nucleic acid delivery: lentiviral and retroviral vectors. Mater methods. 2013;3:174.

Figura 13. Confecção do vetor lentiviral

\subsubsection{Ensaio de infecção por lentivírus em células-tronco mesenquimais}

As células-tronco mesenquimais humanas entre as passagens 4 e 6 foram submetidas à infecção por lentivírus contendo as sequências de shRNA controle. Assim como nos ensaios com siRNA, as células foram infectadas ainda em suspensão, ou seja, as células foram misturadas com o vírus enquanto aderiam à placa.

Em cada poço de uma placa de 6 poços, foi utilizado $1 \mathrm{~mL}$ de vírus e $5 \times 10^{4}$ de células na presença de $8 \mathrm{ug} / \mathrm{mL}$ de polibrene. Vinte e quatro horas após a infecção, o meio foi substituído pelo meio Mc4. O sucesso da transdução foi avaliado conforme a número de células que expressaram a proteína GFP. Para tanto, cerca de 10.000 eventos foram analisados no equipamento Attune Nxt (Thermofisher), quanto à positividade das células para a proteína verde fluorescente GFP e utilizamos o Attune ${ }^{T M}$ NxT Software v3.1.2 para realizar as análises. As análises das imagens de contraste de fase e a fluorescência foram realizadas em microscópio confocal Zeiss LSM 710, analisadas no software Zeiss Zen 2.3 lite e quantificadas no software ImageJ 1.53a. 


\subsection{Coleta de Medula óssea - Murinos}

Os procedimentos experimentais utilizando os camundongos da linhagem Rosa26/mTmG (background genético CD-1; Jackson Laboratories, JAX) foram aprovados pelo Comitê de ética de Uso Animal (CEUA), e de acordo com os Princípios éticos em Experimentação Animal adotados pelo Conselho Nacional de Controle de Experimentação Animal (CONCEA). Foram utilizados 14 camundongos entre machos e fêmeas, com 4-60 semanas de idade, sendo separados em grupos de jovens com até 24 semanas e grupos mais velhos entre 56 e 60 semanas. Em todos os experimentos os camundongos foram avaliados diariamente quanto ao seu estado de saúde, aqueles que demonstraram desconforto, incômodo, apatia ou outros problemas relacionados aos procedimentos experimentais eram eutanasiados para evitar sofrimento. O procedimento para retirada do material ósseo/medular, realizado no Centro de Experimentação e Treinamento em Cirurgia, é feito após anestesia geral dos animais via inalação de Isoflurano (Attane - Bayer Nova Zelândia) seguida de eutanásia por deslocamento cervical. O material coletado é acondicionado em solução de salina fisiológica sob gelo, até o isolamento das células pelo flush medular, onde os ossos fêmures e tíbias dos camundongos são lavadas pela inserção de uma seringa na cavidade óssea, lavados como meio Mc5, conforme procedimento ilustrado abaixo (Figura 14). 

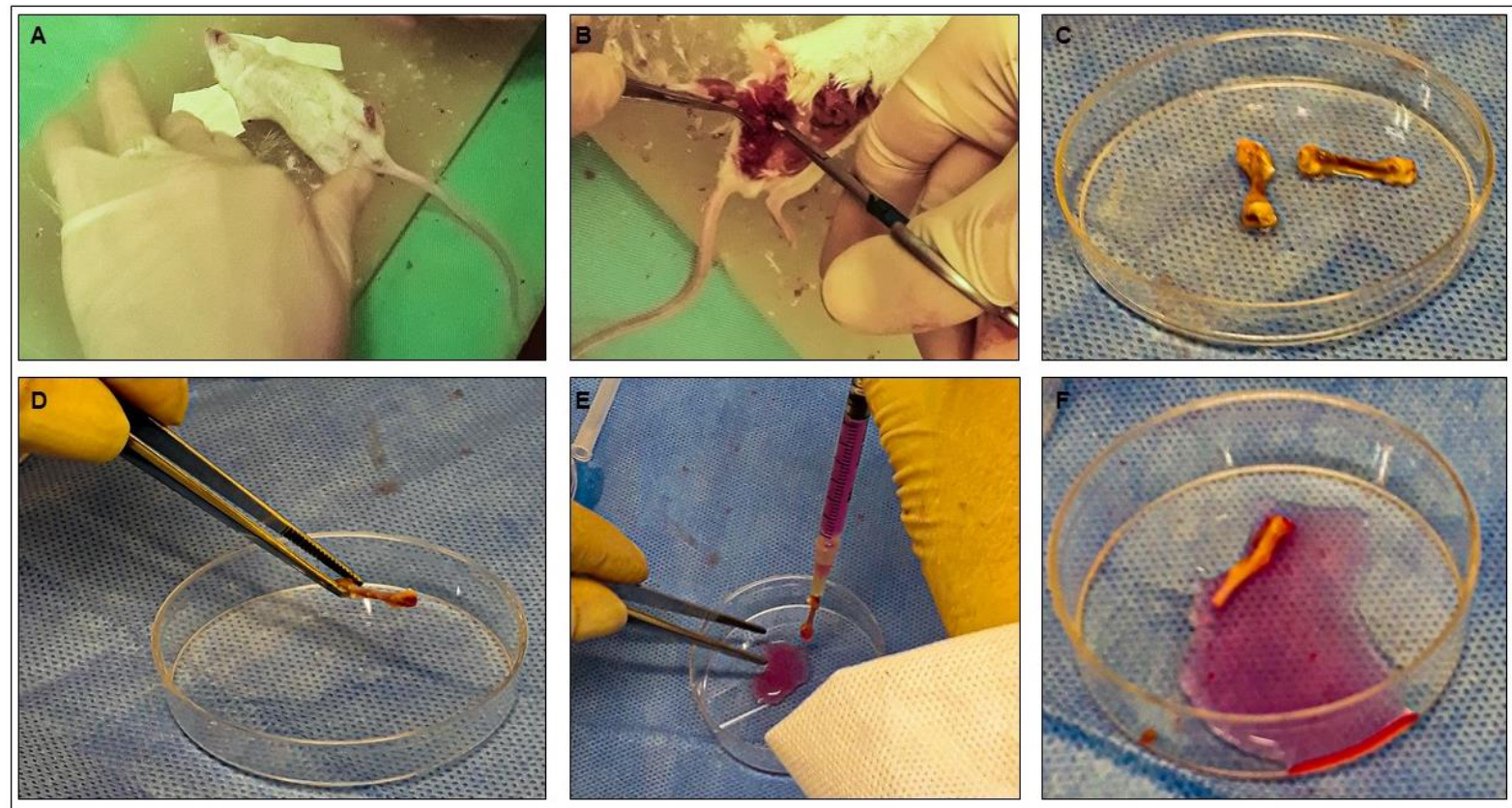

(A) Os camundongos foram eutanasiados por deslocamento cervical (B) Tíbias e fêmures foram dissecados; músculos, ligamentos e tendões foram removidos (C) Ossos foram transferidos para uma placa de cultura estéril (D) Os ossos foram lavados duas vezes para remover as impurezas, com álcool $70 \%$ e PBS $1 x$ estéril, as duas extremidades logo abaixo do final da cavidade medular foram excisado com bisturi. (E) Uma agulha foi inserida na cavidade óssea e usada para lavar lentamente a medula com o meio DMEM suplementado. $(F)$ As cavidades ósseas foram lavadas até os ossos empalidecerem e toda a medula óssea fosse retirada.

Figura 14. llustrações do procedimento de coleta de células da medula óssea de camundongos

\subsection{Cultivo das células-tronco mesenquimais murinas}

As CTMs de camundongos foram isoladas de acordo com a metodologia descrita por Nadri et al. ${ }^{(126)}$ Resumidamente, após o procedimento de flush citado acima, por meio do qual a MO é removida da cavidade óssea usando meio de cultura Mc5, as células são retiradas das placas e incubadas em garrafas de $25 \mathrm{~cm}^{2}$ a $5 \%$ de $\mathrm{CO}_{2}$ e $37^{\circ} \mathrm{C}$. As células não aderentes são removidas 24 horas depois, pela substituição do meio de cultura. As primeiras células fusiformes aparecem aproximadamente no terceiro dia e, em seguida, a cultura se torna mais confluente e atinge $70 \%$ a $90 \%$ de confluência entre 2 e 4 dias. Após atingirem a confluência, as células foram lavadas com PBS 1x e descoladas da placa com 2,5mL de tripsina a 0,25\% com EDTA 1x (Gibco, Carlsbad, CA) por até no máximo 3 minutos a $37^{\circ} \mathrm{C}$, depois a tripsina foi neutralizada com 7,5mL de meio Mc5. Então, as células foram transferidas para um tubo Falcon de $15 \mathrm{~mL}$, centrifugadas a $500 \mathrm{~g}$ por 5 minutos. Após centrifugação, as células foram ressuspendidas e dependendo da concentração, uma parte das células foram congeladas e outra parte novamente em cultura com garrafas de $25 \mathrm{~cm}^{2}$ ou $75 \mathrm{~cm}^{2}$ 
com a aproximadamente $1 \times 10^{4}$ de células $/ \mathrm{cm}^{2}$. As passagens foram realizadas em média entre 4 e 6 dias e as células foram armazenadas a $-80^{\circ} \mathrm{C}$ para experimentos futuros.

\subsection{Caracterização imunofenotípica de células-tronco hematopoéticas - Murinos}

A caracterização imunofenotípica das células-tronco hematopoéticas murinas foi realizada por citometria de fluxo, os anticorpos monoclonais utilizados foram: Lineage (CD3e, CD11b, CD45R, TER-119, Ly-6G e Ly-6C) - APC, Sca-1 PE-Cy7 (clone: D7) e CD117 PE (clone: 2B8) (BD Pharmingen, San Diego, CA). Além disso, foram utilizadas células não marcadas para controle de fluorescência.

Após o procedimento de flush citado acima, onde a $\mathrm{MO}$ é removida da cavidade óssea utilizando $1 \mathrm{~mL}$ de meio de cultura Mc5, utilizamos $200 \mu \mathrm{L}$ de cada camundongo para quantificação. As células foram marcadas com anticorpos monoclonais de interesse acima citados, incubadas em temperatura ambiente protegidas da luz por 30 minutos. Após esse período, as células foram lavadas com T2, centrifugadas a $500 \mathrm{~g}$, por 5 minutos a $22^{\circ} \mathrm{C}$, ressuspendidas em $100 \mu \mathrm{L}$ de solução tampão T2 e adquiridas em citômetro de fluxo FACS Fortessa - LSR II (BD Biosciences, San Jose, CA). Os dados obtidos foram analisados no software FLOWJO (TreeStar, Ashland, OR).

\subsection{Padronização do transplante de células-tronco mesenquimais - murinos}

A padronização do transplante de células-tronco mesenquimais murinas iniciou-se com a injeção de corante azul de metileno dentro do fêmur dos camundongos para certificarmos que todo volume seria injetado na cavidade medular dos animais. Além disso, foram testadas quantidades variadas de corante, $20 \mu \mathrm{L}, 30 \mu \mathrm{L}$ e $50 \mu \mathrm{L}$, assim como o método cirúrgico e a anestesia. Para este procedimento, os camundongos foram anestesiados em cone nasal com isofluorano 2,8\% (Attane - Bayer Nova Zelândia). Após confirmar a analgesia com teste de pinçamento da cauda e das falanges, a região do joelho foi tricotomizada e realizada antissepsia com álcool $70^{\circ}$. Posteriormente, a articulação do joelho foi flexionada ao máximo e uma agulha foi introduzida na epífise do fêmur. O corante foi injetado na cavidade medular, os animais 
foram eutanasiados por deslocamento cervical e os fêmures dissecados para observação da coloração (Figura 15).

Após a padronização com o corante, foram realizados testes para a padronização do transplante com as CTMs de camundongos da linhagem Rosa26/mTmG (Tomate ${ }^{+}$) (background genético CD-1; Jackson Laboratories, JAX) previamente coletadas e expandidas em cultura conforme descrito no capítulo 2.20. O objetivo desta padronização foi garantir que as CTMs sejam inseridas e visualizadas na MO do fêmur do camundongo receptor wild type (background C57BL/6) Tomate:

Para tanto, os camundongos foram anestesiados em cone nasal com isofluorano 2,8\% (Attane - Bayer Nova Zelândia) e, após confirmar a analgesia com teste de pinçamento da cauda e das falanges, a região do joelho foi tricotomizada e realizado antissepsia com álcool $70^{\circ}, 1 \times 10^{6}$ CTMs dos camundongos Rosa26/mTmG, ressuspendidas em $20 \mu \mathrm{L}$ de PBS, foram transplantadas por via intrafemoral, com auxílio de uma agulha $0,8 \mathrm{~mm}$ de calibre $30 \mathrm{G}$ (BD ultrafina), anexa a uma seringa de $0,3 \mathrm{~mL}$, foi introduzida na epífise dos fêmures. Em um dos fêmures foi injetada a suspensão celular e, para controle, no outro fêmur foram injetados $20 \mu \mathrm{L}$ de PBS. Logo em seguida, cada animal recebeu analgésico opioide (tramadol, 40mg/kg) via subcutânea a cada 12 horas, durante 3 dias.

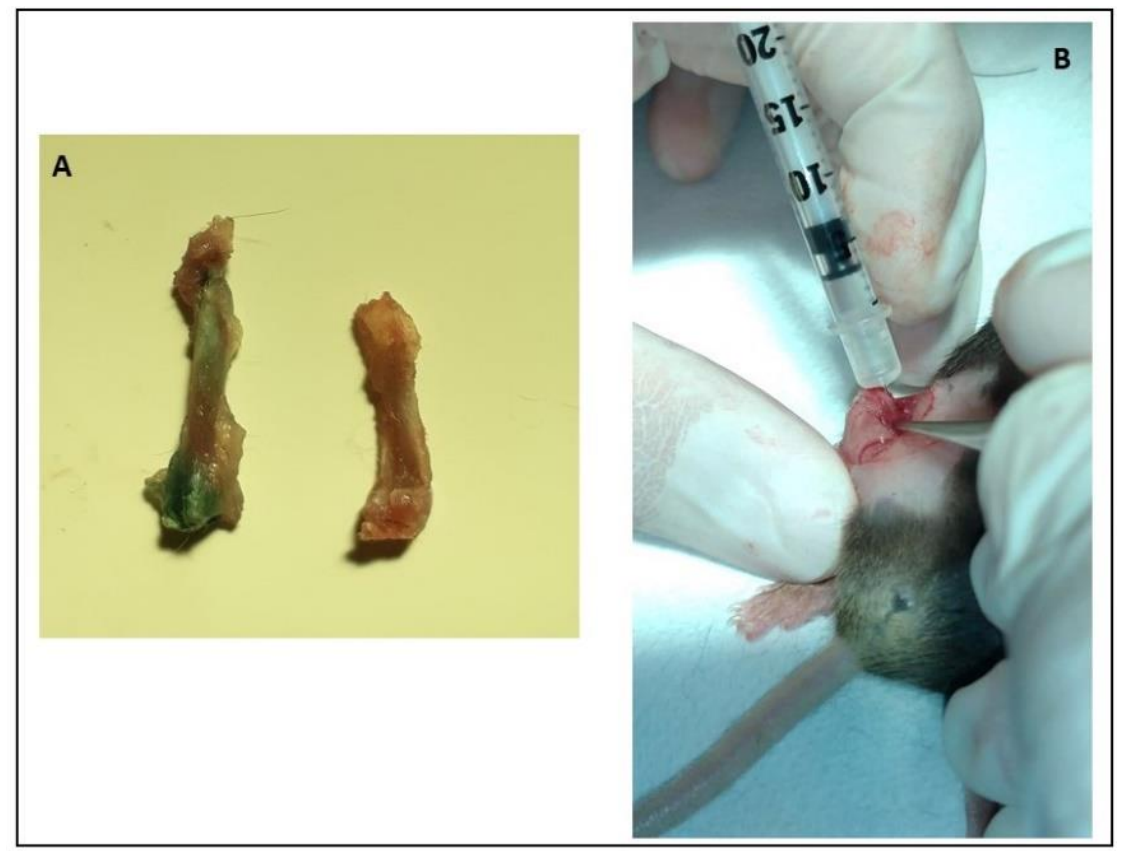

(A) Os fêmures foram dissecados para visualização do teste de injeção do corante azul de metileno. À esquerda observa-se o fêmur que foi injetado corante, à direita o osso em que houve injeção de PBS. (B) llustração da agulha introduzida na epífise do fêmur, acessando a medula óssea para injeção das CTMs.

Figura 15. Ilustrações do teste com injeção do corante na medula e do procedimento de injeção das células-tronco mesenquimais na medula óssea 


\subsection{Citometria de fluxo para avaliação da técnica de transplante de células-tronco mesenquimais - camundongos Rosa26/mTmG}

Para a avaliação da técnica de transplante de CTMs Tomate $^{+}$de camundongos Rosa26/mTmG inseridas na MO femoral de camundongos (background C57BL/6). Os camundongos foram anestesiados em câmara de indução com isofluorano $4 \%$, sacrificados por deslocamento cervical, os fêmures dissecados e as medulas ósseas isoladas por flush, conforme descrito no item 2.19.

Para avaliar o mosaicismo de CTMs do camundongo selvagem com as células do camundongo Rosa26/mTmG, após o flush da medula, as hemácias foram lisadas com tampão de lise (BD FACS lysing solution 1x - BD FACS ${ }^{\mathrm{TM}}$ ), logo em seguida, quantificadas no citômetro de fluxo Attune Nxt (Thermofisher). Cerca de 10.000 eventos foram analisados no laser amarelo (YL1) quanto à positividade das células para 0 fluorocromo Tomate. Para as análises e ajuste dos parâmetros do citômetro foram

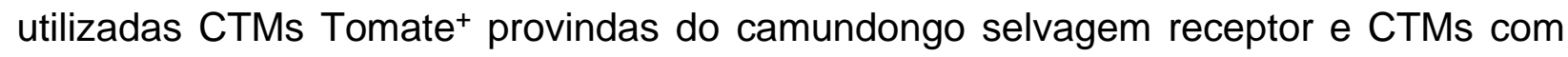
fluorescência provenientes do camundongo doador Rosa26/mTmG (Tomate ${ }^{+}$. Utilizamos o Attune ${ }^{\mathrm{TM}}$ NxT Software v3.1.2 para realizar as análises.

\subsection{Análise estatística}

As análises estatísticas foram realizadas no programa GraphPad Prisma versão 6.02 de 2013. Foi utilizado o teste $t$ de Student para comparação entre 2 grupos e o teste de Wilcoxon ou Mann-Whitney foram utilizados para distribuição não normal das amostras. O teste ANOVA (One-way Anova) foi utilizado para comparações de mais de 2 grupos com correção de Dunnett. O resultado das análises foi considerado significativo quando apresentaram resultados de $p \leq 0,05$. 


\section{RESULTADOS}

\subsection{Caracterização de células-tronco mesenquimais da medula óssea}

As CTMs foram obtidas a partir de MO de indivíduos saudáveis. As células foram isoladas de filtros descartáveis utilizados na coleta de MO de doadores para transplante. Para confirmar se as células isoladas eram realmente CTMs, realizamos os testes requeridos pela Sociedade Internacional de Terapia Celular (ISCT - International Society for Cellular Therapy), a caracterização imunofenotípica como mostrado na figura 16A e a capacidade de diferenciação em três linhagens de origem mesodérmica (osteoblasto, condrócitos e adipócitos) como mostrado na figura 16 (B-D). Todas as CTMs utilizadas neste estudo preencheram estes requisitos.

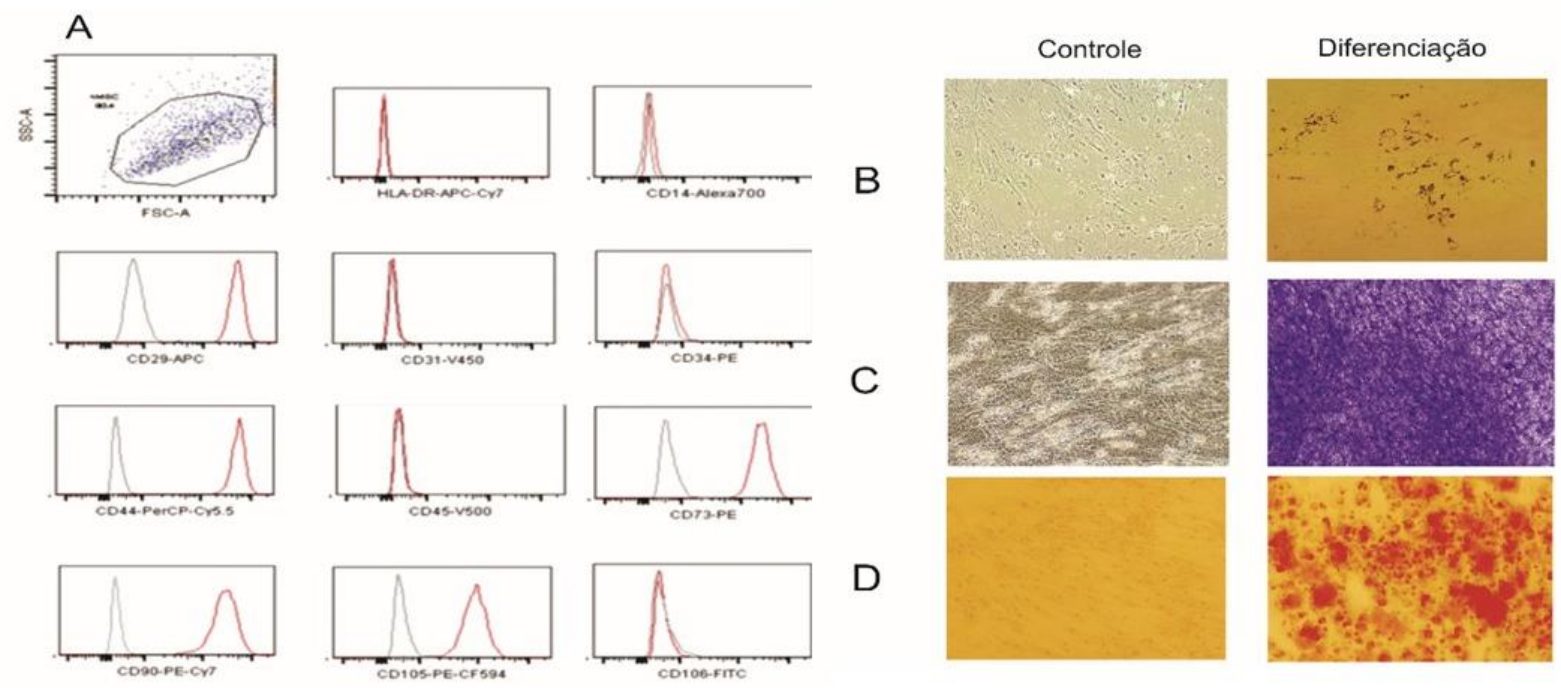

Imunofenotipagem - (A) Estratégia de seleção, o gate inicial foi realizado segundo tamanho (FSC) versus granulosidade (SSC). Histogramas selecionados a partir do gate inicial mostram células sem marcação - controle (cinza) e as células marcadas (vermelho), sendo a expressão menor que 1\% para os marcadores CD14, CD31, CD34, CD45, CD106 e HLA-DR e acima de 98\% para CD29, CD44, CD73, CD90 e CD105. Diferenciação em 3 linhagens (B) Diferenciação para adipócitos marcam em vermelho (oil red) para inclusões lipídicas intracelulares; (C) Diferenciação para condrócitos marcam em azul (toluidine-blue) para presença de proteoglicanos; (D) Diferenciação para osteoblastos marcam em vermelho (alizarin red) para depósitos de cálcio.

Figura 16. Caracterização do perfil das células mesenquimais 


\subsection{Caracterização de células-tronco hematopoéticas de sangue de cordão umbilical}

As CTHs foram obtidas a partir de $\mathrm{SCU}$, as células foram isoladas através de seleção positiva de CD34. Para verificar o perfil das células isoladas, realizamos citometria de fluxo utilizando o protocolo ISHAGE, ${ }^{(121,122,127)}$ como mostrado na figura 17. Em geral as seleções CD34 tiveram uma pureza superior a $80 \%$.
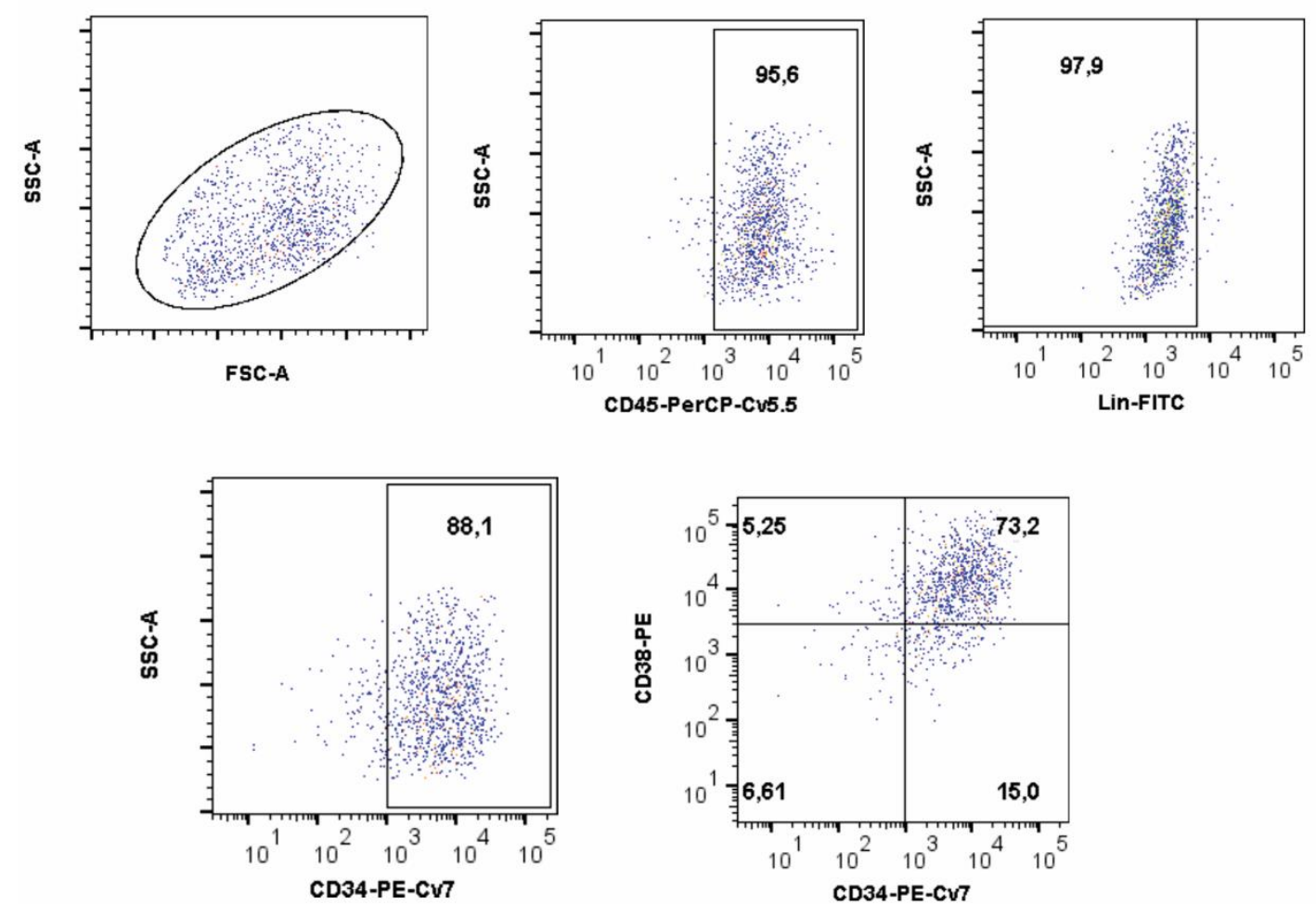

As células foram selecionadas inicialmente por tamanho e granulosidade (SSC versus FSC), em seguida as células $C D 45^{+}$foram selecionadas para delimitar a população total de leucócitos, após a seleção CD45 os leucócitos que expressaram marcadores de linhagem (diferenciados) foram excluídos a partir da seleção somente de células Lin negativas e depois a população de células CD34+ foi selecionada. A partir do "gate" de células CD34+, as subpopulações de células CD34+ foram caracterizadas pela expressão do marcador CD38.

Figura 17. Perfil de expressão fenotípica de células-tronco hematopoéticas isoladas de sangue de cordão umbilical após seleção CD34

\subsection{Tratamento in vitro com CXCL12 aumenta o número de células-tronco hematopoéticas indiferenciadas (CD34+CD38-)}

Nosso grupo demonstrou, anteriormente, que há diminuição na secreção de CXCL12 pelas células-tronco mesenquimais de indivíduos idosos (>60 
anos) e o cocultivo dessas células-tronco mesenquimais senescentes influenciaram um perfil mais diferenciado nas CTHs. ${ }^{(118)}$ Uma vez que CXCL12 é uma importante molécula encontrada no nicho medular e secretada também pelas células-tronco mesenquimais, ${ }^{(15,70,77)}$ avaliamos o papel da quimiocina CXCL12 nas células-tronco hematopoéticas.

Para tanto, isolamos células-tronco hematopoéticas provenientes de SCU de quatro doações e as cultivamos durante 3 e 7 dias com CXCL12. Após o cultivo, identificamos as subpopulações de CTHs, identificadas pela expressão dos marcadores CD45, Lineage, CD34 e CD38 cuja estratégia de "gate" está representada na figura 17. As subpopulações das células CD34+ CD38- representam células mais precursoras, enquanto que as subpopulações ${\mathrm{CD} 34^{+}}^{\mathrm{CD}_{3} 8^{+}}$representam progenitores hematopoéticos mais diferenciados, portanto, que podem estar comprometidos com alguma linhagem.

As quantificações foram realizadas por citometria de fluxo no dia 0 (não ilustrado), imediatamente após a separação magnética por coluna de afinidade e, após 3 e 7 dias de cultivo com ou sem tratamento de CXCL12, sendo que as CTHs sem tratamento foram consideradas o grupo controle.

A percentagem de células entre o grupo controle e grupo tratado com CXCL12, não apresentou diferença significativa em relação ao dia 3 de cultivo nos fenótipos de progenitores hematopoético CD34+ ${ }^{+}$D38+ e CD34+ CD38- Entretanto, no dia 7 de cultivo houve aumento significativo na percentagem de células com perfil mais indiferenciado CD34+ CD38- que receberam tratamento de CXCL12 (valor-p 0,03, Figura 18A) e diminuição na percentagem das células mais diferencias CD34+ CD38+ que receberam tratamento de CXCL12 (valor-p 0,01, Figura 18B). Portanto, sugerimos que a presença de CXCL12 tenha uma função importante na "repopulação" dos progenitores hematopoéticos, podendo assim, contribuir para manutenção do estoque de célulastronco hematopoéticas mais progenitoras no nicho medular. 
A

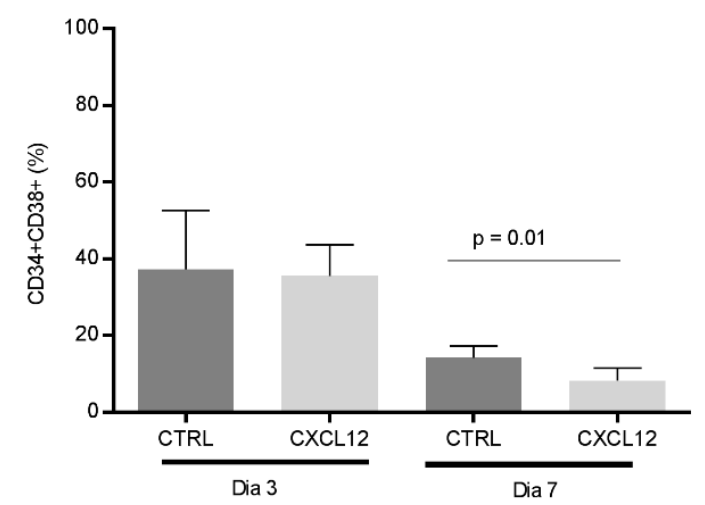

B

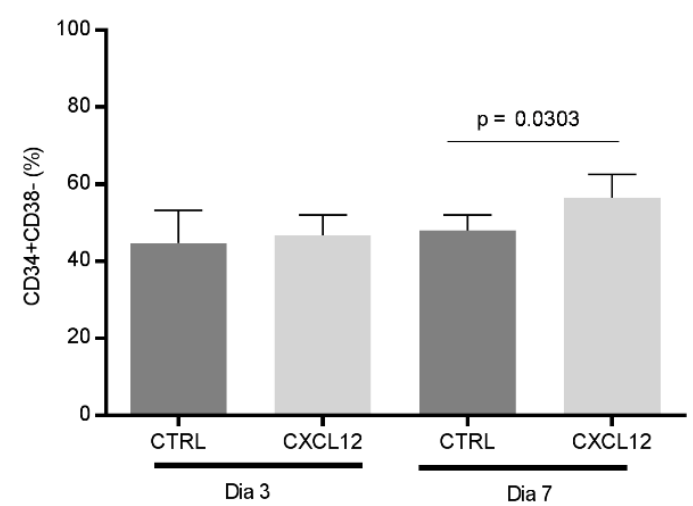

Células-tronco hematopoéticas provenientes de sangue de cordão umbilical foram mantidas em cultura por 0,3 ou 7 dias, na presença ou ausência (CTRL) de CXCL12 e posteriormente avaliadas por citometria de fluxo. (A) Percentagem de CTHs (CD34+CD38+-) nos dias 3 e 7 de cultivo, (B) Percentagem de CTHs (CD34+CD38-) nos dias 3 e 7 de cultivo. Os experimentos foram realizados em triplicata, os resultados representados por média \pm DP e considerados significativos quando $p \leq 0,05$ (ANOVA). CTRL: cultivo de CTHs sem CXCL12; CXCL12: cultivo de CTHs com tratamento de CXCL12. $n=4$.

Figura 18. CXCL12 induz aumento no número absoluto de células-tronco hematopoéticas indiferenciadas CD34 ${ }^{+}$CD38

\subsection{Células-tronco hematopoéticas cultivadas com CXCL12 apresentam declínio na expressão de genes relacionados à diferenciação de linhagem hematopoética}

Ainda buscando esclarecer o impacto da quimiocina CXCL12 nas células-tronco hematopoéticas (CD34 $)$, no mesmo experimento citado na figura acima, as CTHs obtidas de SCU de quatro doadoras foram mantidas em cultura e após sete dias com e sem tratamento de CXCL12, o RNA total foi extraído, o cDNA foi transcrito e analisado por PCR em Tempo Real. Os genes de diferenciação de linhagem hematopoética PU.1 (Figura 19A), GATA 2 (Figura 19B), GATA3 (Figura 19C) e IKZF1 (Figura 19D) foram normalizados pelos genes GAPDH e RPL13a, expressos como número de vezes em relação ao controle, demonstrados no gráfico como expressão relativa. Todos os ensaios foram realizados em triplicata e estão representados por média de expressão. Os genes PU.1 (valor-p 0,0001 Figura 19.A), GATA2 (valor-p 0,0015 Figura 19B) e IKZF1 (valor-p 0,0010 Figura 19D) tiveram diminuição significativa em suas expressões nas CTHs cultivadas com a quimiocina CXCL12 quando comparados ao controle. Os fatores PU.1 e GATA2 estão associados à diferenciação mieloide, ${ }^{(40,49,128,129)}$ enquanto IKZF1 e GATA3 estão relacionados à diferenciação linfoide. ${ }^{(130-134)}$ Perante os resultados de análise do perfil gênico expresso e, 
corroborando os resultados de fenótipo (Figura 18), podemos reforçar que a quimiociona CXCL12 pode prevenir a diferenciação das células-tronco hematopoéticas in vitro, uma vez que induz a diminuição da expressão de fatores de transcrição envolvidos no comprometimento dessas células com a diferenciação para as linhagens hematopoéticas.
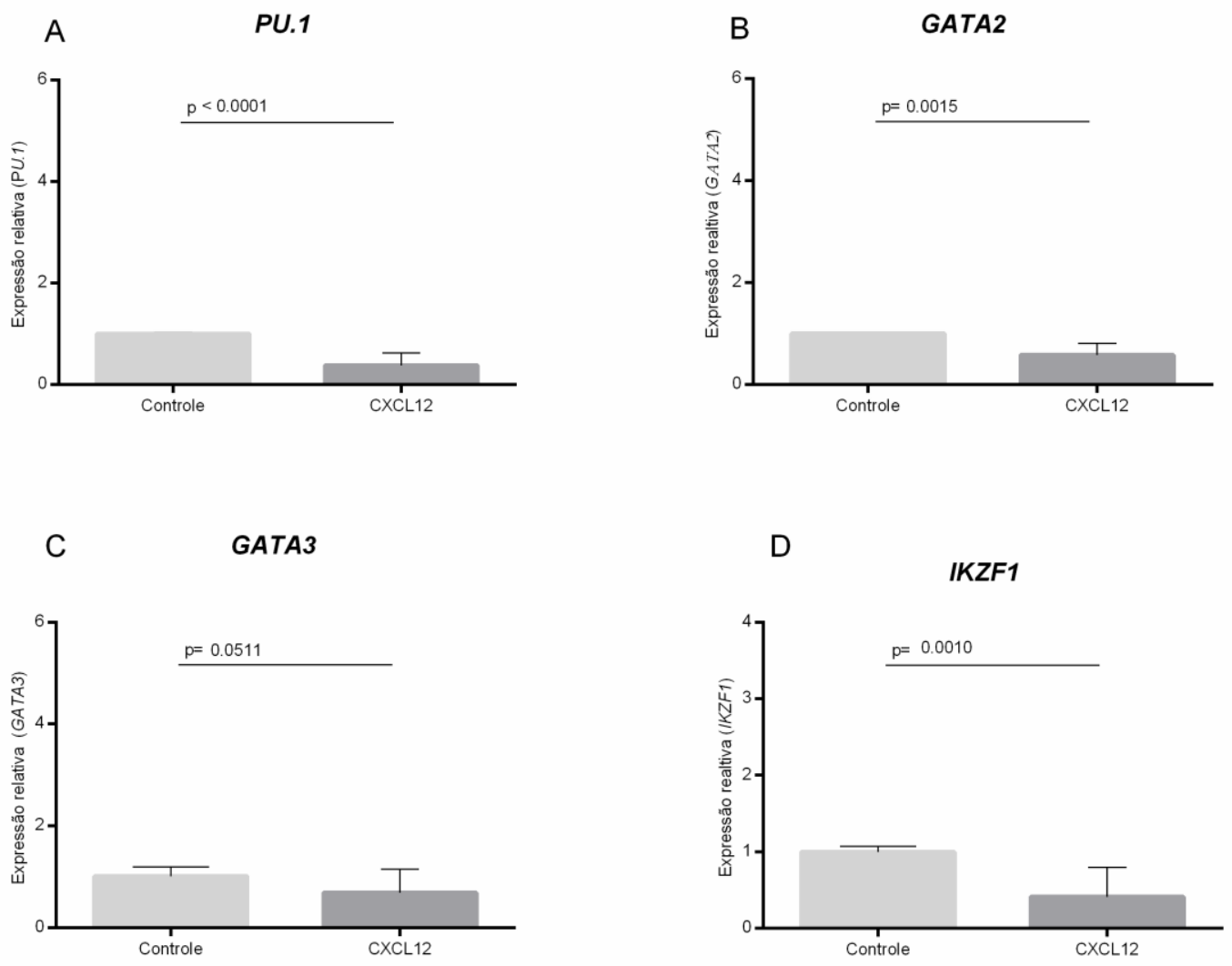

CTHs foram mantidas em cultura por 7 dias na presença ou ausência (CTRL) de CXCL12. Após esse período, avaliamos por RT-qPCR a expressão dos genes (A) PU.1, (B) GATA2, (C) GATA3 e (D) IKZF1, normalizada pelos genes GAPDH e RPL13a, expressos como número de vezes em relação ao controle (expressão relativa). Os experimentos foram realizados em triplicata, os resultados representados por média $\pm D P$ e considerados significativos quando $p \leq 0,05$ (Teste $t$ ). CTRL: cultivo de CTHs sem CXCL12; CXCL12: cultivo de CTHs com tratamento de CXCL12. $\mathrm{n}=4$.

Figura 19. Tratamento com CXCL12 induz redução na expressão gênica dos fatores de transcrição ligados à diferenciação de linhagem hematopoética nas células-tronco hematopoéticas

\subsection{Presença de CXCL12 aumenta a expressão gênica de fatores de transcrição relacionados à autorrenovação celular nas células-tronco hematopoéticas in vitro}

Com o foco no envolvimento do CXCL12 na manutenção da autorrenovação e para dar continuidade à investigação das funções desta quimiocina 
nas células-tronco hematopoéticas, foram realizados ensaios de expressão gênica dos fatores de transcrição relacionados à multipotência. O RNA total das células foi extraído após sete dias de cultura com ou sem CXCL12, o cDNA transcrito e o perfil gênico analisado por qPCR. Os genes de multipotência KLF4 (Figura 20A), NANOG (Figura 20B), POU5F1 (Figura 20C), SOX2 (Figura 20D), HOXB4 (Figura 20E) e NOTCH1 (Figura 20F) foram normalizados pelos genes GAPDH e RPL13a, expressos como número de vezes em relação ao controle, plotados no gráfico como expressão relativa. Todos os ensaios foram realizados em triplicata e estão representados por média de expressão. Com exceção do POU5F1, HOXB4 e NOTCH1 (Figuras 20C, E e F), os outros fatores de transcrição, KLF4 (valor-p 0,0358 Figura 20A), NANOG (valor-p 0,0153 Figura 20B), SOX2 (valor-p 0,0078 Figura 20D) apresentaram aumento significativo na expressão gênica nas células cultivadas na presença de CXCL12. Deste modo, nossos dados confirmam a participação desta quimiocina na preservação e manutenção do estado indiferenciado das células-tronco hematopoética por meio do aumento da expressão gênica de fatores de transcrição relacionados a esta função. 
A

KLF4

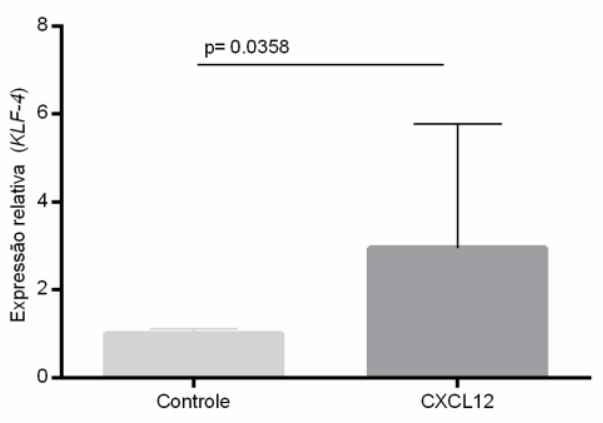

C

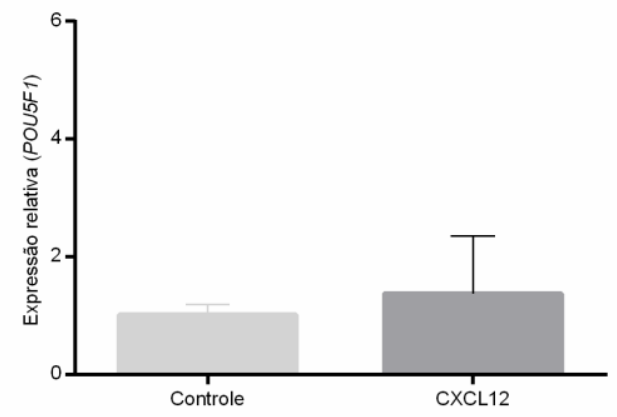

E

HOXB4

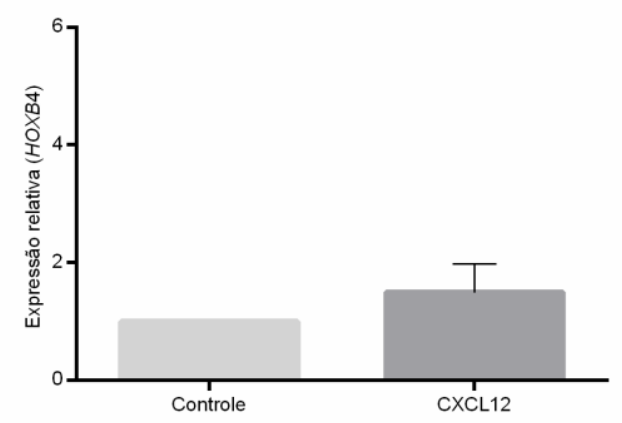

B

NANOG

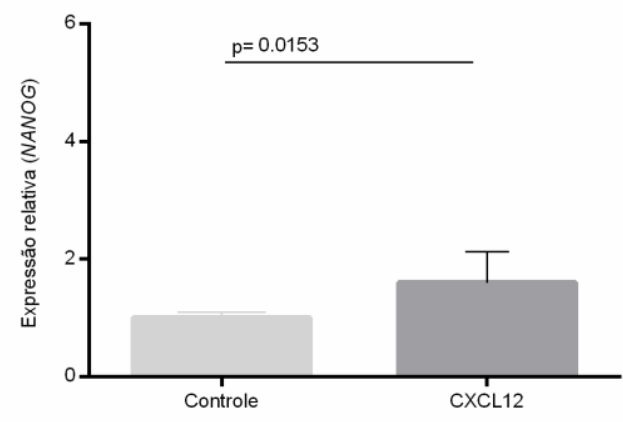

D

SOX2

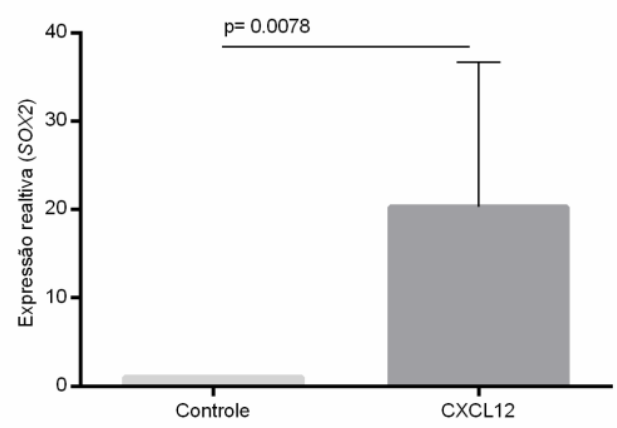

F

NOTCH1

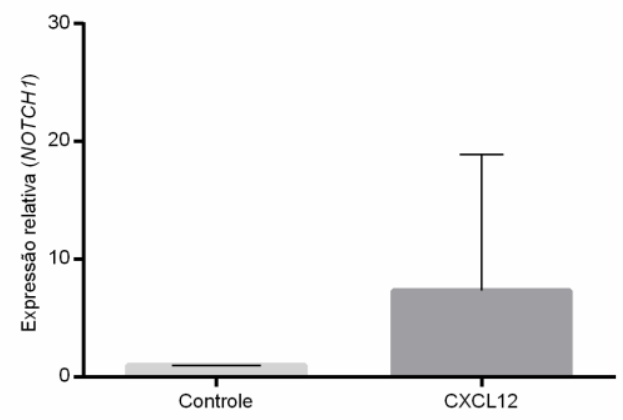

CTHs foram cultivadas por 7 dias na presença ou ausência (CTRL) de CXCL12. Após esse período, avaliamos por RT-qPCR a expressão dos genes de multipotência $(A), K L F 4,(B)$ NANOG, (C) POU5F1 e (D) SOX2. (E) HOXB4 (F) NOTCH1. Os dados foram normalizados pelos genes GAPDH e RPL13a, expressos como número de vezes em relação ao controle (expressão relativa). Os experimentos foram realizados em triplicata, os resultados representados por média $\pm D P$ e considerados significativos quando $p \leq 0,05$ (Teste t). CTRL: cultivo de CTHs sem CXCL12; CXCL12: cultivo de CTHs com tratamento de CXCL12. $n=4$. Figura 20. Expressão dos genes relacionadas a multipotência nas células-tronco hematopoéticas com e sem tratamento de CXCL12 


\subsection{CXCL12 contribui para o aumento da expressão proteica da proteína Beta- catenina nas células-tronco hematopoéticas}

As proteínas envolvidas na via Wnt são secretadas pelas células mesenquimais presentes no nicho medular(92,99,135,136) atuando funcionalmente nas células-tronco hematopoéticas. A ativação da proteína Beta-catenina está relacionada à via canônica desta sinalização. Com o propósito de avaliar o papel da quimiocina CXCL12 na expressão da Beta-catenina analisamos a expressão gênica e proteica dessa proteína nas células-tronco hematopoéticas na presença ou ausência de CXCL12, contudo, não observamos diferença significativa na expressão gênica de Beta-catenina entre os grupos de células avaliados (Figura 21A).

Quanto à expressão proteica da Beta-catenina nas mesmas células, verificamos através do ensaio de microscopia confocal, que as células-tronco hematopoéticas $\left(\mathrm{CD}^{+} 4^{+}\right)$cultivadas com CXCL12 (Figura 21C e 21E) por 7 dias apresentam mais células, sendo $6 \%$ células marcadas no controle e, com tratamento de CXCL12 foram 23\% células marcadas por campo expressando beta-catenina (Figura 21B e 21D).

Em nossos experimentos, apesar de observamos resultados variáveis na expressão gênica de Beta-catenina entre as amostras, não houve diferença estatística entre células-tronco hematopoéticas com ou sem tratamento de CXCL12 (Figura 21A). Embora a análise proteica tenha apresentado aumento na marcação para Beta-catenina nas CTHs que receberam tratamento de CXCL12 (Figura 21C a 21F). 

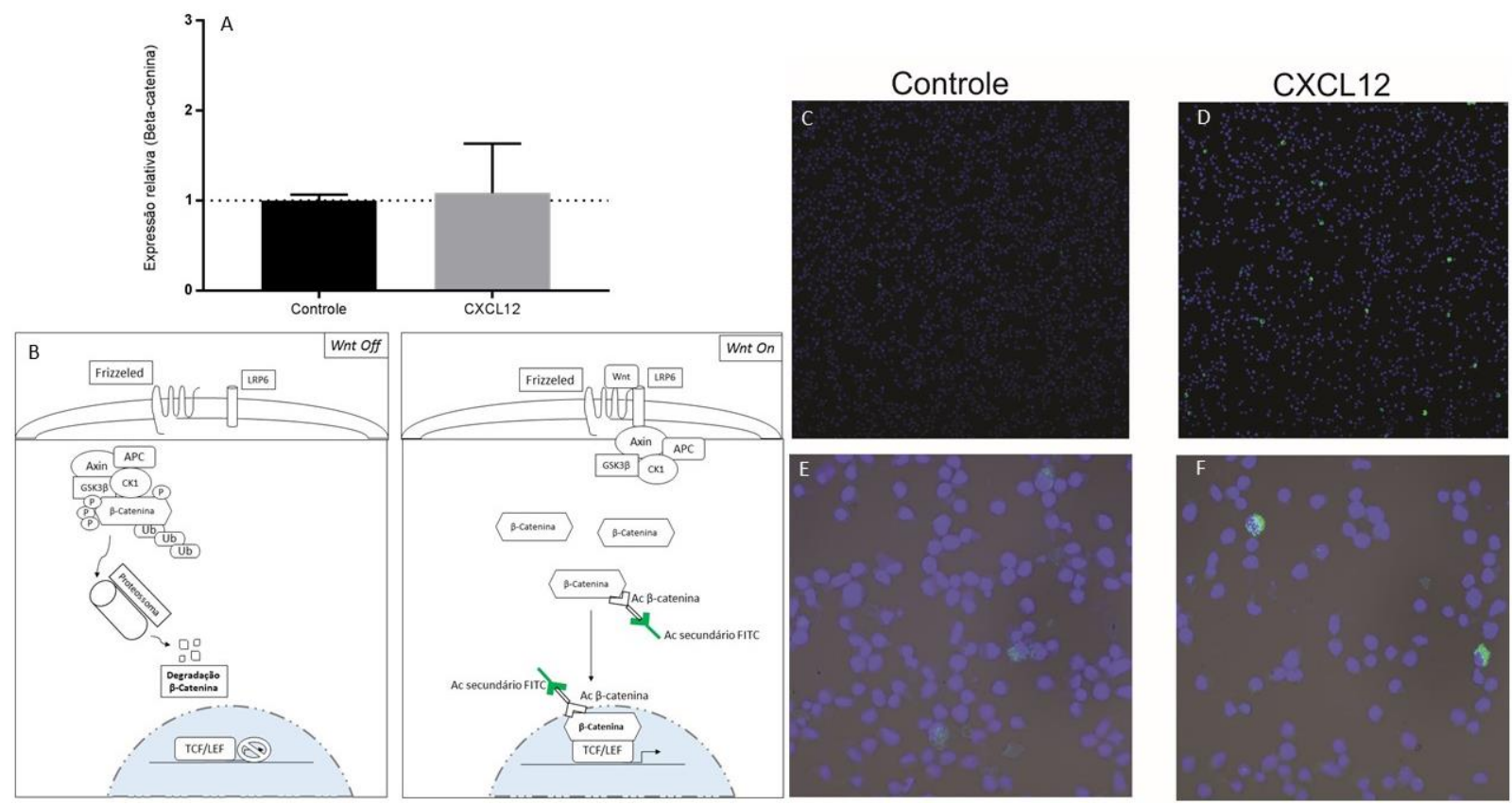

No sétimo dia de cultura, com e sem tratamento de CXCL12, o RNA total foi extraído das CTHs, a expressão gênica foi analisada por RT-qPCR e expressão proteica analisada por microscopia confocal. (A) A expressão gênica da proteína Beta-catenina, foi normalizada pelos genes GAPDH e RPL13a, expressos como número de vezes em relação ao controle (fold-change), realizado em triplicata e resultados representados por média \pm DP. (B) Esquema ilustrativo simplificado da via canônica de sinalização da proteína $\beta$-catenina, demonstrando a ligação do anticorpo anti- $\beta$-catenina1 e secundário FITC utilizado durante a análise de confocal. (C, D, E e F) CTHs marcadas com anti- $\beta$-catenina e DAPI, controle e tratamento de CXCL12 em campo escuro - aumento de 10x. (D, E) e campo claro - aumento de 40x. CTRL: cultivo de CTHs sem CXCL12; CXCL12: cultivo de CTHs com tratamento de CXCL12. $\mathrm{n}=4$.

Figura 21. Expressão gênica e proteica da proteína Beta-catenina nas células-tronco hematopoéticas após tratamento com CXCL12

\subsection{Silenciamento de CXCL12}

\subsubsection{Avaliação da citotoxicidade no ensaio de transfecção em células-tronco mesenquimais}

Para estabelecer o protocolo e condições ideais para os ensaios de transfecção, avaliamos a citotoxicidade do agente de transfecção. Avaliou-se o procedimento de transfecção com CTMs, segundo descrição no item 2.18. O grau de citotoxidade foi calculado a partir da razão entre o valor de Ct do gene utilizado como gene de referência, o RPL13a, das amostras transfectadas com o controle negativo, das amostras não transfectadas, das amostras expostas somente ao agente de transfecção e das amostras transfectadas com siRNA CXCL12 (Ct Neg \#1 $\div$ Ct não transfectado/ou $\mathrm{Ct}$ amostras transfectadas $=$ fator de citotoxicidade). Os valores calculados, mostraramse próximos a 1 para todas as condições avaliadas, indicando baixa citotoxicidade do 
ensaio.

Em relação a avaliação da eficiência, a mesma foi calculada em função da porcentagem de inibição do gene alvo. A avaliação da expressão do gene CXCL12 após inibição da expressão gênica foi validada em células-tronco mesenquimais, o fator de citotoxicidade foi sempre baixo. Não foram observadas alterações na morfologia das células transfectadas, assim como na viabilidade celular e também não houve diferença entre a formação de debris durante o ensaio de citometria.

\subsubsection{Avaliação da eficiência no ensaio de transfecção - siRNA}

O ensaio de transfecção teve como objetivo a inibição da expressão do RNA mensageiro da quimiocina CXCL12. Para tal ensaio, utilizamos um inibidor sintético dessa molécula, que são fitas simples de ácidos nucleicos desenhados especificamente para se ligar e inibir moléculas de RNAs mensageiros endógenos. O silenciamento do CXCL12 foi realizado utilizando siRNA e a eficiência do silenciamento e sua duração foram analisadas por PCR em tempo real, citometria para detecção de CXCL12 intracelular (não secretado) e ensaio de ELISA para detectar a secreção do CXCL12.

Observamos que a porcentagem de expressão gênica remanescente do CXCL12 após dois dias do silenciamento foi em média de $26 \%$ em relação ao controle negativo, sendo muito próximo do recomendável pelo fabricante que é de $25 \%$, entretanto, no terceiro dia após transfecção a expressão remanescente de CXCL12 subiu para $77 \%$ (Figura 22).

Quando verificamos a proteína CXCL12 intracelular, não observamos inibição significativa da CXCL12 quando comparada ao controle sem tratamento ou com o tratamento de lipofectamina ou siRNA para CXCL12, os dias 3, 4 e 5 após transfecção das células. Quando observamos a média de intensidade de fluorescência (MFI) da CXCL12, verificamos uma tendência de redução de expressão nos dias 3 e 4, mas aumento compensatório no dia 5 após transfecção (Figura 23B).

Para verificar a secreção de CXCL12, realizamos o ensaio de ELISA para mensurar a concentração desta quimiocina no sobrenadante das células em cultura por 3 e 4 dias. Porém, novamente não observamos inibição significativa na secreção da 
quimiocina CXCL12 quando comparada ao siRNA controle ou com o tratamento de siPORT $^{\circledR} \mathrm{NeoFx}^{\mathrm{TM}}$ (Figura 24).

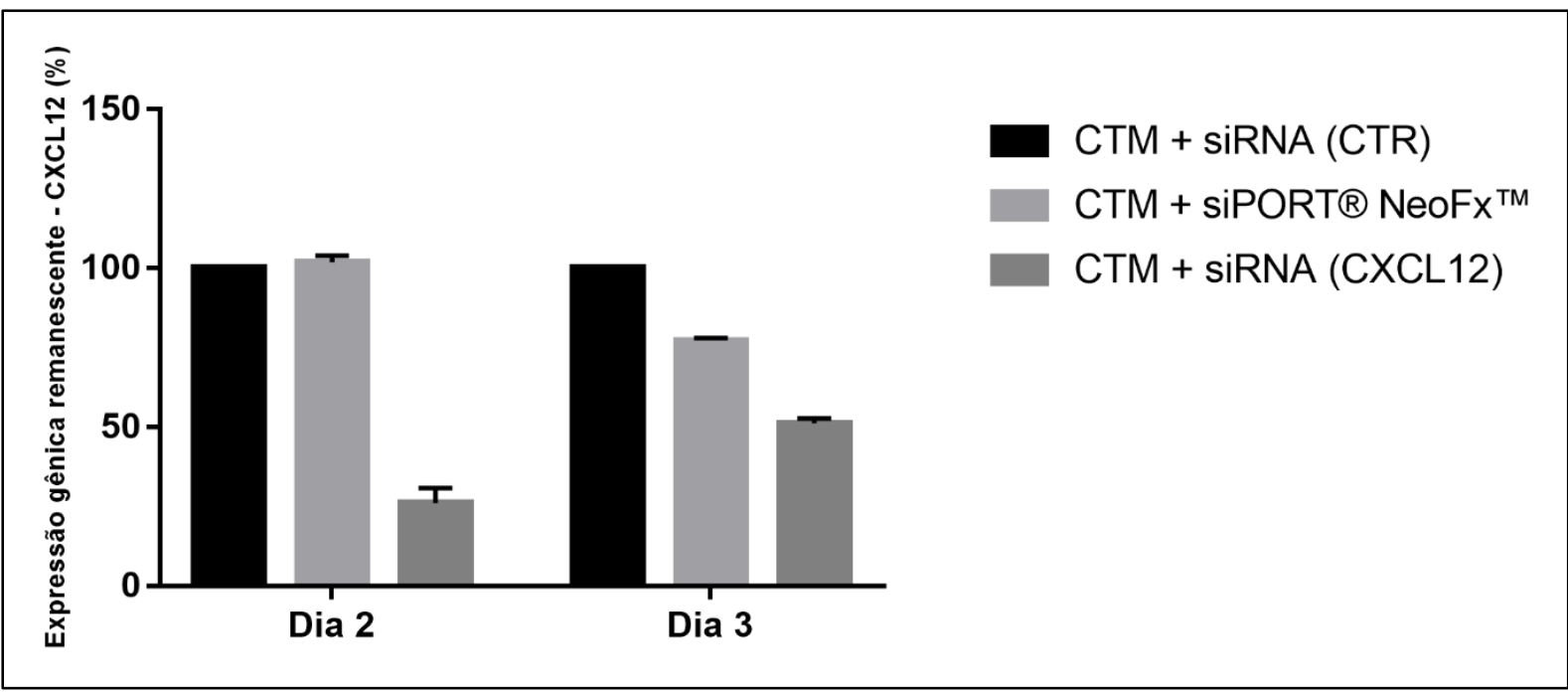

Após o silenciamento da quimiocina CXCL12 com siRNA observamos expressão gênica remanescente de $26 \%$ em relação ao controle, $51 \%$ de expressão gênica remanescente no dia 3 . Os dados foram normalizados pelos genes RPL13a, expressos como número de vezes em relação ao controle x 100 . Os experimentos foram realizados em triplicata, os resultados representados pela média entre as replicatas técnicas.

Figura 22. Expressão gênica remanescente de CXCL12 após silenciamento com siRNA

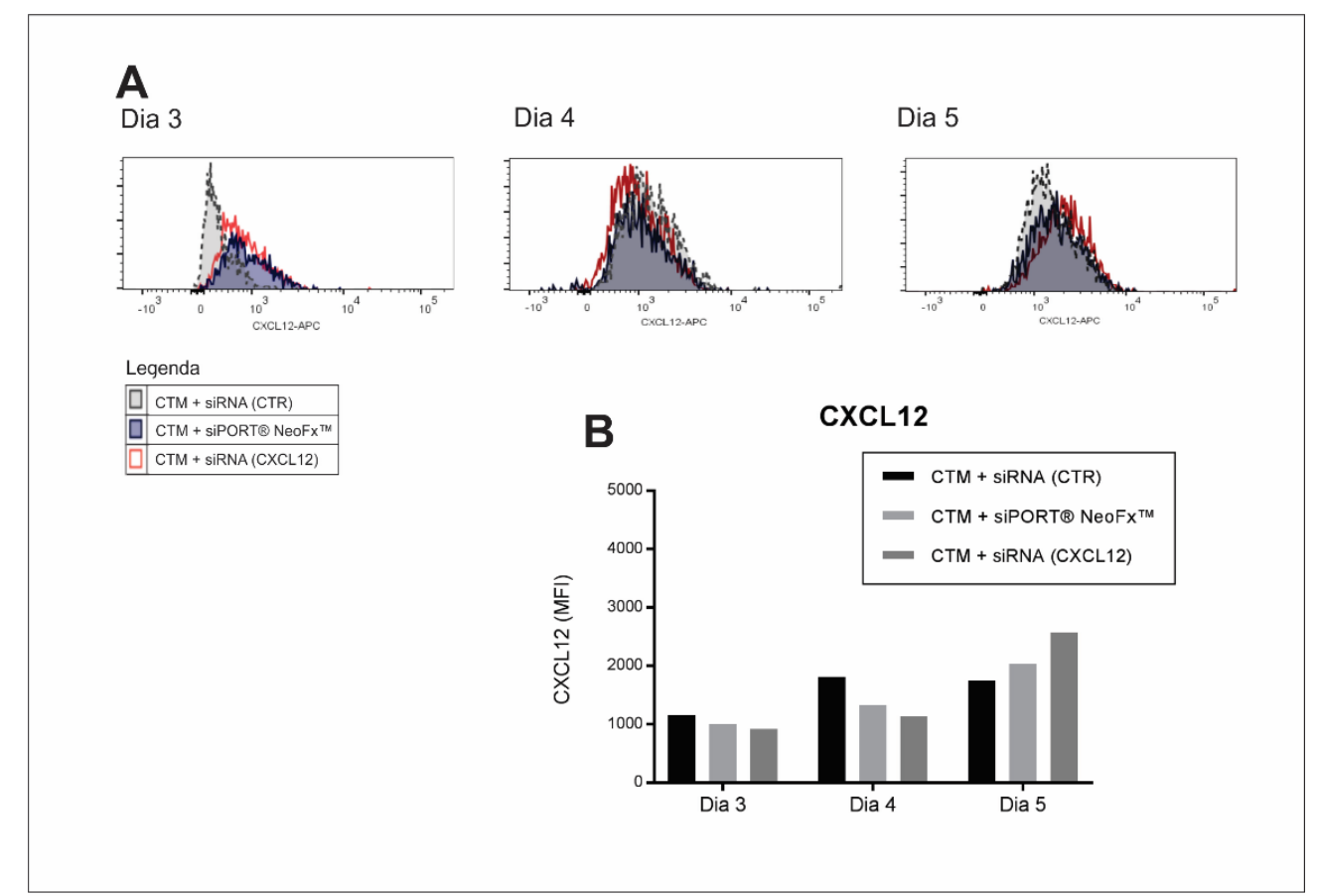

Nos dias 3, 4 e 5 de cultura das células após silenciamento do CXCL12 com siRNA não observamos diferença significativa de expressão proteica intracelular entre 0 controle, as células tratadas somente com agente de transfecção e as tratadas com siRNA para CXCL12 (A) gráficos de citometria nos dias 3, 4 e 5 com sobreposição da expressão do CXCL12 (B) gráfico representativo do MFI nas condições controle, tratamento com agente de transfecção apenas e com siRNA para CXCL12.

Figura 23. Expressão intracelular de CXCL12 após o silenciamento com siRNA 


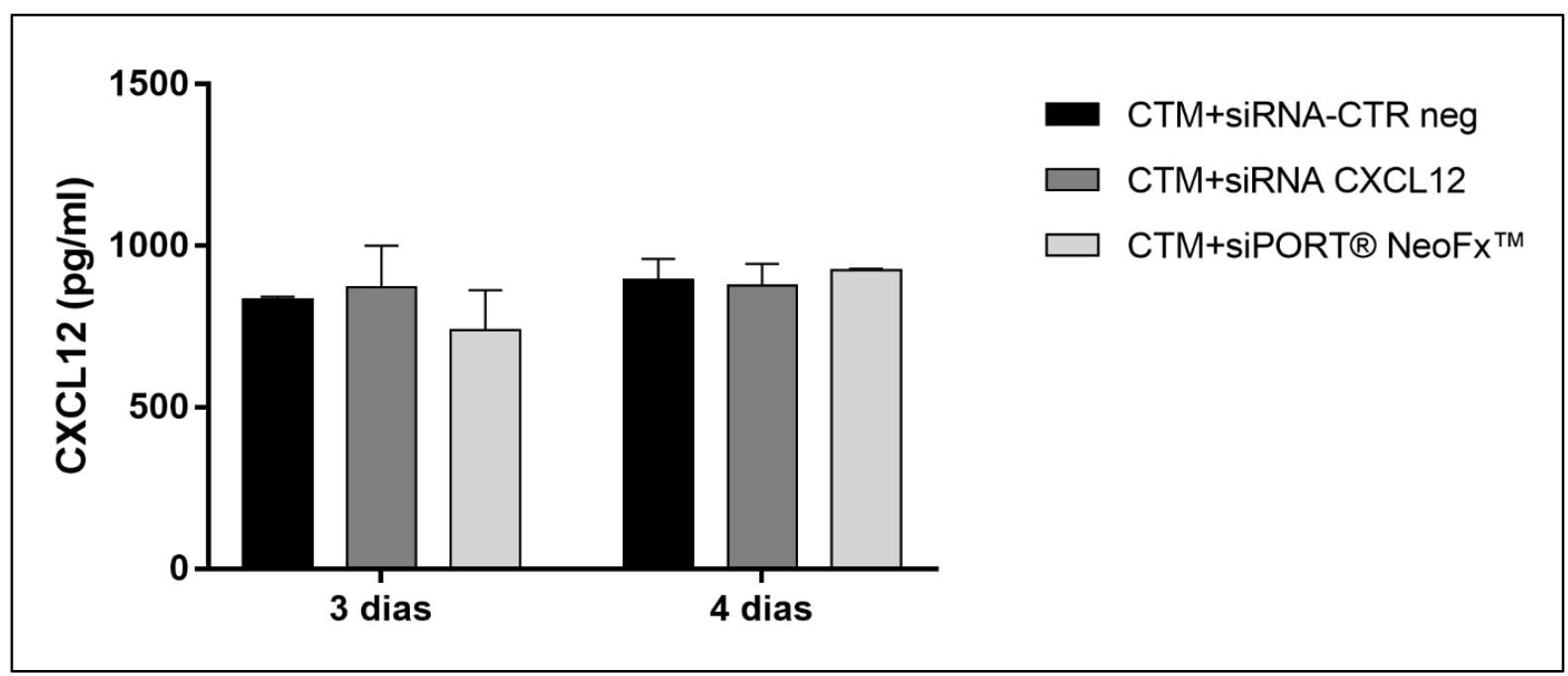

Nos dias 3 e 4 de cultura das células após silenciamento do CXCL12 com siRNA não observamos diferença significativa de expressão proteica secretada entre o controle, as células tratadas somente com agente de transfecção siPORT ${ }^{\circledR} \mathrm{NeoFx}^{\mathrm{TM}}$ e as tratadas com siRNA para CXCL12. Os experimentos foram realizados em duplicata, os resultados estão representados pela média.

Figura 24. Expressão de CXCL12 secretado após o silenciamento com siRNA

\subsubsection{Transfecção versus transdução em células-tronco mesenquimais}

Atualmente, duas abordagens básicas são usadas para entrega de material genético nas células: transfecção, utilizada primeiramente neste estudo para siRNA, e infecção de células com vírus. A transfecção é geralmente realizada por produtos químicos ou métodos físicos (como por exemplo siPORT ${ }^{\circledast} \mathrm{NeoFx} x^{\mathrm{TM}}$, utilizado neste trabalho), através da qual a entrega do material de interesse às células é mais simples, mas geralmente é de baixa eficiência, especialmente para CTMs. ${ }^{(137)}$ Por outro lado, a infecção viral envolve infectar células-alvo com um vírus utilizando-o como ferramenta para entregar o material genético de interesse, se mostrando uma alternativa muito eficiente. ${ }^{(137)}$ Nas duas técnicas é possível que DNA do plasmídeo seja transfectado e utilizando um constructo de plasmídeo contendo um promotor padrão de citomegalovírus que dirige a expressão da proteína, é possível visualizar o sucesso da transfecção.

Portanto, devido ao resultado transitório do silenciamento do mRNACXCL12 utilizando siRNA, iniciamos outra estratégia utilizando a transfecção de plasmídeos contendo shRNA, com o objetivo do silenciamento duradouro ou permanente. Conforme representado na figura 12 no item 2.18.5 da metodologia, o vetor pLL3.7 possui duas repetições terminais longas (LTRs), um sítio de clonagem para a 
inserção das sequencias shRNA logo depois do promotor U6 humano, o gene codificador da proteína GFP sob controle do promotor CMV (citomegalovírus).

\title{
3.7.4 Digestão do plasmídeo e análise dos clones
}

O primeiro passo foi digerir o plasmídeo pLL3.7 com as enzimas Hpal e Xhol, o objetivo desta reação é tornar o plasmídeo linear e permitir a inserção das sequências de interesses. Uma alíquota da reação foi analisada em gel de agarose, juntamente com o plasmídeo não-digerido como controle (Figura 25). Podemos observar na figura 25 que a reação ocorreu de forma satisfatória, no poço 1 o plasmídeo encontrase na forma fechada ou enovelada, por isso, podemos visualizar mais de uma banda, devido aos diferentes níveis de enovelamento da molécula. Já no poço 2 , a molécula encontra-se linear, sendo assim, avança menos na eletroforese pois dessa forma aberta tende-se a enganchar nas redes da agarose.

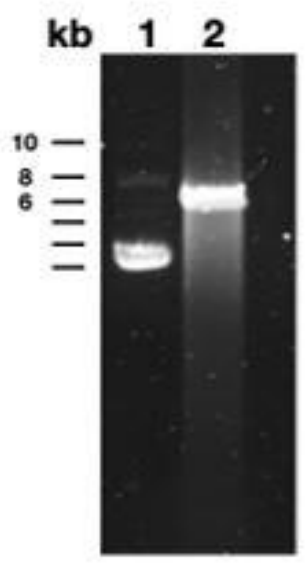

\begin{abstract}
Marcador de peso molecular $1 \mathrm{~kb}$ plus (Invitrogen, Carlsbad, CA), kb = quilobases; 1 plasmídeo pLL3.7 não-digerido. 2 - plasmídeo pLL3.7 digerido com as enzimas Hpal e Xhol. Figura 25. Perfil eletroforético do plasmídeo pLL3.7 após digestão
\end{abstract}

Após a digestão do vetor, seguimos para inserção das sequências de shRNA nos plasmídeos, como descrito no item 2.18.6. A reação de ligação foi empregada para transformar bactérias e a análise dos clones foi realizada através de PCR de colônia, os plasmídeos dos clones positivos foram purificados e analisados por 
PCR para confirmação das clonagens. A técnica de PCR permitiu a amplificação dos fragmentos de interesse, ou seja, evidenciar a presença da banda de tamanho aproximadamente 560pb quando houve ligação correta entre o vetor e o shRNA-CXCL12 e também para o controle (vetor vazio) com aproximadamente 532pb (Figura 26).

A figura abaixo exemplifica alguns dos clones que a ligação entre vetor (plasmídeo) e inserto (shRNA) ocorreu de forma satisfatória e dentro do esperado (clones 2, 3, 4, 5 e 10). Entretanto, podemos observar também que alguns clones não houve ligação do vetor ao shRNA de interesse ou ocorreu a formação de produtos inespecíficos $(1,6,7,8,9,11,12$ e 13).

Após esta avaliação, seguimos somente com os clones que identificamos que a ligação do shRNA ao plasmídeo ocorreu.

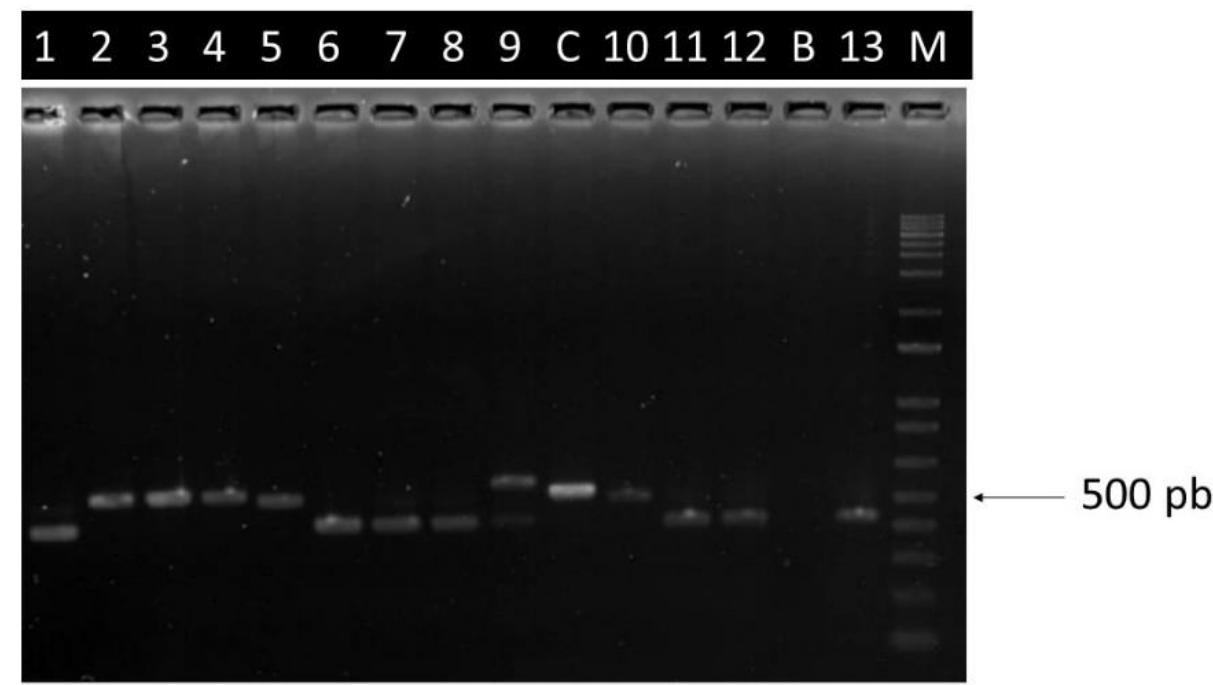

C: Controle do vetor vazio; M: Marcador $1 \mathrm{~Kb}$ (Invitrogen, Carlsbad, CA); 2, 3, 4,5 e 10 são exemplos de clones em que houve ligação entre inserto e plasmídeo; $1,6,7,8,9,11,12$ e 13 são exemplos de clones em que não ocorreu a inserção do inserto ao plasmídeo; B: Branco, adicionado água à reação de PCR. Gel agarose $1 \%$.

Figura 26. Análise dos clones após amplificação por reação em cadeia da polimerase

\subsubsection{O agente de transfecção siPORT ${ }^{\circledR}$ NeoFx ${ }^{\mathrm{TM}}$ não foi eficiente para transfecção de plasmídeo}

Após a análise dos clones, iniciamos a padronização da transfecção do plasmídeo contendo shRNA controle em células-tronco mesenquimais utilizando siPORT ${ }^{\circledR} N e o F X^{\mathrm{TM}}$, os resultados foram avaliados conforme a porcentagem de células 
expressando a proteína GFP. As transfecções foram realizadas utilizando diferentes

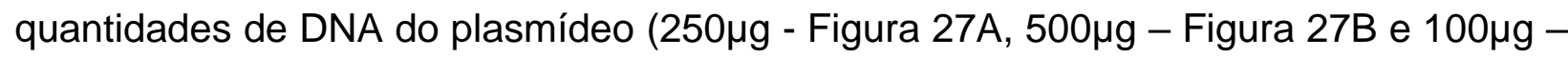
Figura 27C), sempre avaliando as características de vaibilidade celular, testamos até a concentração máxima de agente de transfecção, e o máximo de número de células transfectadas obtidas ficou próximo a 10\%, a quantificação da expressão da proteína GFP foi realizada no software ImageJ.

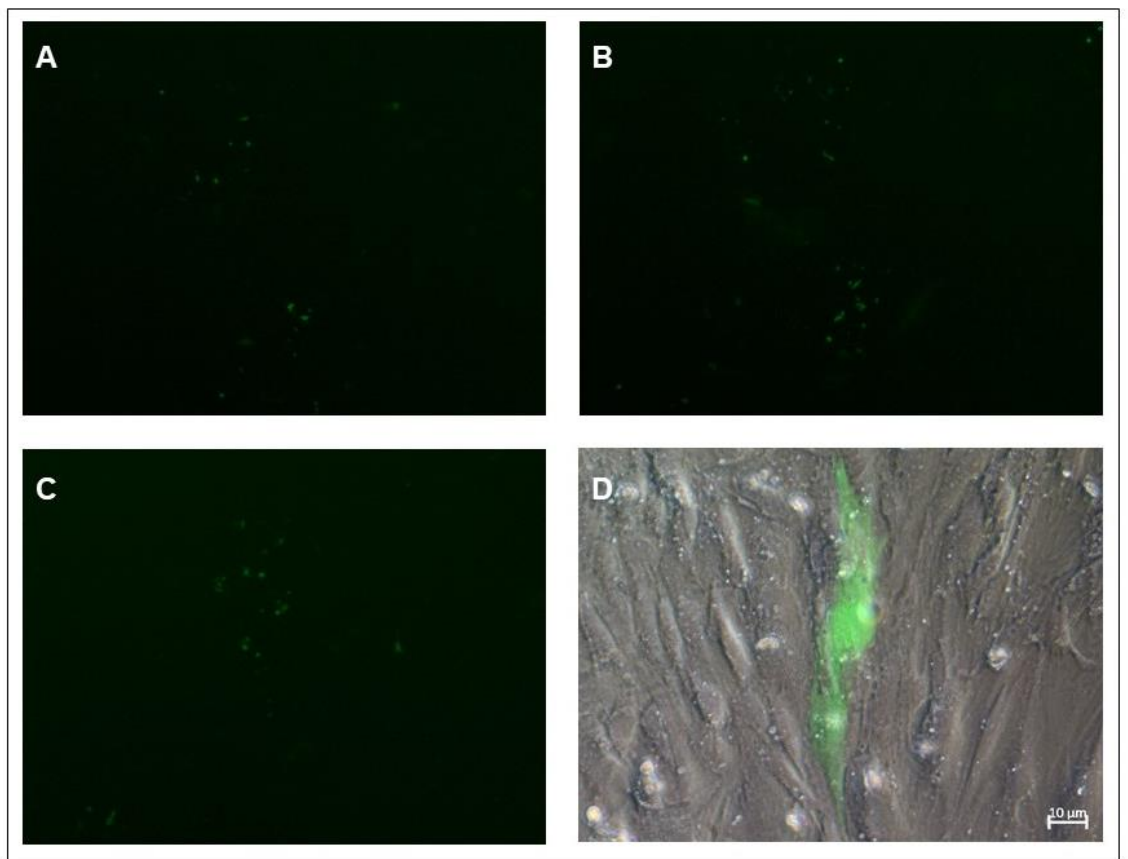

(A) Microscopia de fluorescência em aumento de 25x, expressão de GFP nas células transfectadas com 250 $\mathrm{gg}$ de DNA plasmidial, (B) $500 \mu \mathrm{g}$ de DNA plasmidial e (C) $1000 \mu \mathrm{g}$ de DNA plasmidial. (D) Células transfectadas com $500 \mu \mathrm{g}$ de DNA plasmidial, análise de sobreposição entre expressão de GFP e contraste de fase - aumento de 100x.

Figura 27. Fotografia das células-tronco mesenquimais transfectadas com vetor pLL3.7 utilizando siPORT ${ }^{\circledR} \mathrm{NeoFx}^{\mathrm{TM}}$

\subsubsection{Produção dos vetores virais nas células HEK-293T}

Devido à baixa eficiência na transfecção dos plasmídeos, iniciamos a padronização da infecção por lentivírus. O lentivírus é um vírus de RNA fita dupla capaz de transduzir tanto células quiescentes quanto em divisão, integram seu genoma vetorial no genoma do hospedeiro, garantindo a expressão de longo prazo dos transgenes. ${ }^{(138,139)}$

No presente estudo, as partículas lentivirais foram criadas por cotransfecção de uma linhagem de células Hek-293T com o plasmídeo de transferência 
expressando shRNA juntamente a dois plasmídeos auxiliares de empacotamento que codificam as proteínas estruturais e de envelope (PAX2 e VSV-G). As células empacotadoras produzem partículas infecciosas, cujo genoma codifica apenas sequências do plasmídeo de transferência, que foram transduzidas em células-tronco mesenquimais humanas.

Após 24 horas de infecção, avaliamos a transdução nas células Hek293T, primeiramente as células foram analisadas em relação às caraterísticas morfológicas por microscopia em contraste de fase, enquanto que a análise da expressão do gene repórter GFP foi observada por microscopia de fluorescência, e por fim, realizamos a sobreposição entre a fluorescênica e contraste de fase, a quantificação da expressão da proteína GFP foi realizada no software ImageJ (Figura 28A, 28B e 28C).

Os resultados desta análise demonstraram que não houve alteração da morfologia das células HEK-293T. A expressão da proteína GFP mostrou-se de forma homogênea. Os resultados da quantificação demonstraram que aproximadamente 100\% das células expressaram GFP. Após 48 horas, os vírus foram coletados e seguimos para a padronização da infecção em CTMs.

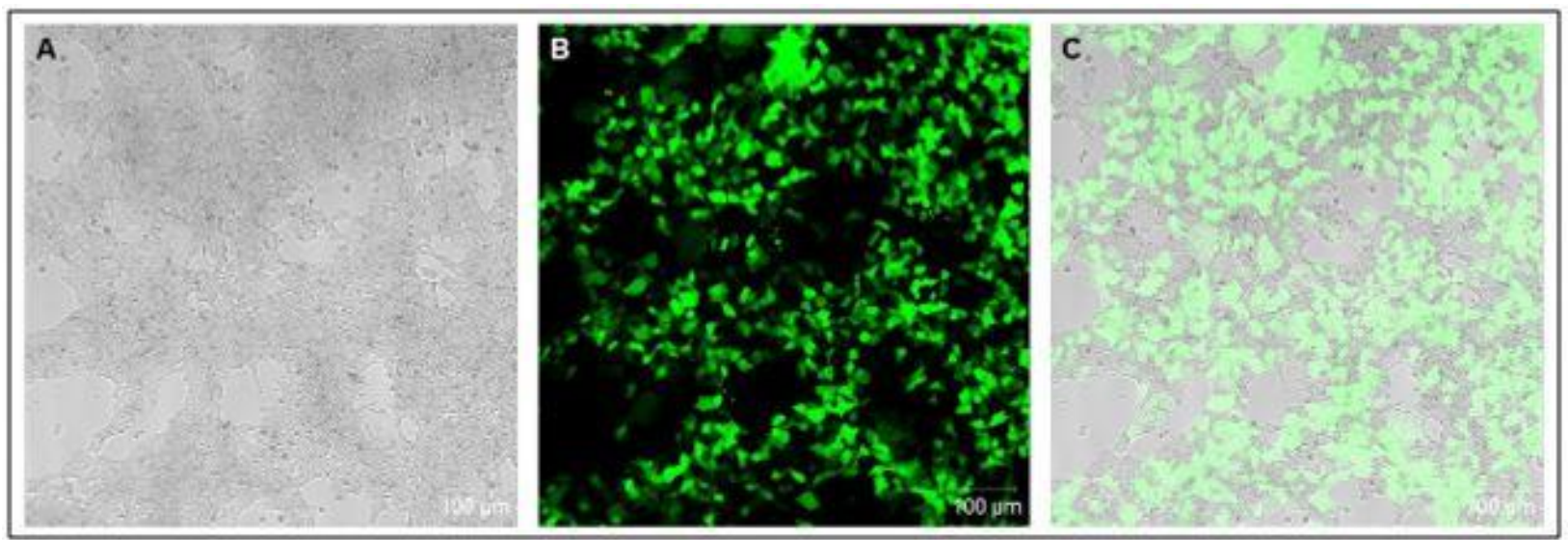

(A) Morfologia das células HEK-293T em contraste de fase. (B) Expressão de GFP nas células HEK-293T, microscopia de fluorescência. (C) Análise de sobreposição entre expressão de GFP e contraste de fase. Figura 28. Fotografias das células HEK-293T após 24 de infecção por lentivírus contendo o plasmídeo shRNA controle

\subsubsection{A eficiência da infecção por lentivírus em células-tronco mesenquimais foi acima de $94 \%$}

Após a produção dos vetores lentivirais em células de empacotamento (Hek-293T), as partículas infecciosas, foram introduzidas em células- 
tronco mesenquimais humanas.

$\mathrm{Na}$ infecção com lentivírus, os trabalhos relatam o uso de polibrene para facilitar a entrada do vírus nas CTMs, ${ }^{(140,141)}$ porém, também existem relatos que isto pode retardar a proliferação celular e induzir senescência. ${ }^{(142,143)}$

Portanto, iniciamos realizando alguns testes em paralelo, infecção com e sem adição de polibrene, células aderidas ou em suspensão e concentração de células. O teste sem adição de polibrene, não houve nenhum ou pouco sinal de transdução.

Realizamos os testes com o polibrene conforme a literatura sugere $(8 \mu \mathrm{g} / \mathrm{mL}),{ }^{140,141)}$ inicialmente por um período de 72 horas, os resultados foram satisfatórios, com uma boa taxa de células que expressaram a protéina GFP (dados não ilustrados).

Para definir a concentração celular, inicialmente utilizamos aproximadamente 10.500 células $/ \mathrm{cm}^{2}$, mas notamos que o número de células infectadas não era satisfatório, então reduzimos para aproximadamente 5.200 células $/ \mathrm{cm}^{2}$ e nesta concentração a porcentagem de CTMs expressando GFP sempre ficou acima de $90 \%$.

Em relação ao teste das células aderidas ou em suspensão, notamos que a confluência celular foi extremamente relevante e, em alguns testes, o período de 24 horas em que as células aderem a placa, a confluência foi alterada, prejudicando a relação entre células e vírus, portanto, optamos em realizar os ensaios com as células em suspensão.

Entretanto, notamos que o período de 72 horas em exposição ao prolibrene prejudicaram a capacidade de proliferação celular. Portanto, realizamos testes com períodos de 16, 24, 48 horas, com exceção de 16 horas, em todos os casos as CTMs expressaram de forma satisfatória a proteína GFP (acima de $90 \%$ ), porém, acima de 24 horas as células perdem a capacidade de proliferação. Sendo assim, os resultados obtidos em CTMs indicam que o melhor período de infecção por lentivírus com adição de polibrene é de 24 horas.

Desta forma, as células foram analisadas em relação as caraterísticas morfológicas por microscopia em contraste de fase após 24 horas de transfecção, enquanto a análise da expressão do gene repórter GFP foi observada por microscopia de fluorescência, e por fim, realizamos a sobreposição entre a fluorescênica e o contraste de fase, a quantificação da expressão da proteína GFP foi realizada por citometria de fluxo e por imagem (Figuras 29A - F). 
Os resultados desta análise demonstraram que não houve alteração da morfologia das células-tronco mesenquimais (Figura 29A - D) e após quantificação, observamos que a porcentagem de células infectadas estavam acima 94\% (Figura 29E e 29F).

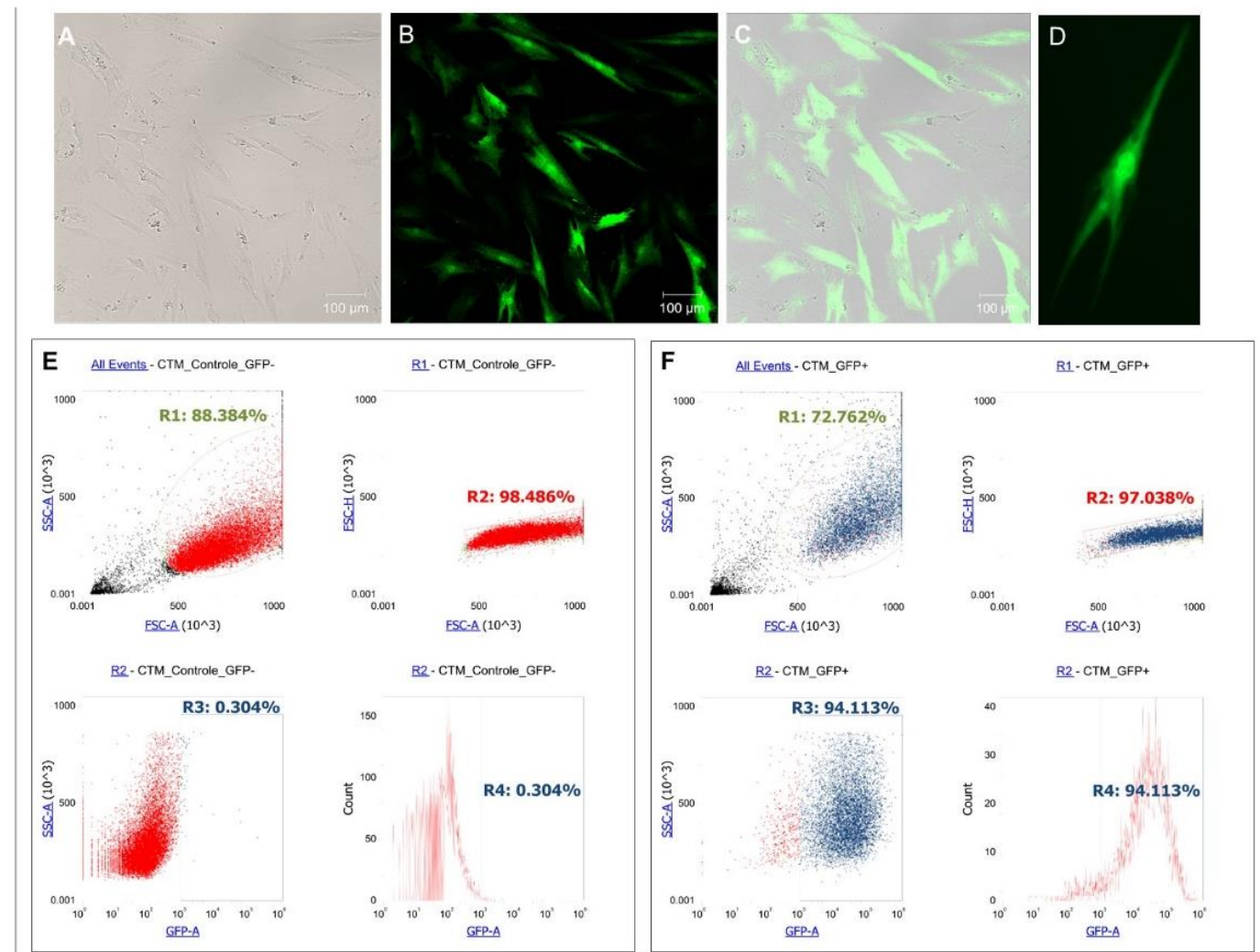

(A) Morfologia das CTMs infectadas em contraste de fase. (B) Expressão de GFP nas CTMs infectadas, microscopia de fluorescência. (C) Análise de sobreposição entre expressão de GFP e contraste de fase. (D) Análise da morfologia por microscopia de fluorescência em CTM expressando GFP. (E,F) Análise por tamanho de granulosidade, análise dos eventos duplos e gráficos de pontos e histogramas mostrando a expressão de CTMs GFP+ (E) controle negativo, CTMs não infectadas (F) CTMs infectadas por lentivírus contendo plasmídeo (shRNA controle). CTMs: células-tronco mesenquimais, GFP: green fluorescence protein.

Figura 29. Fotografias das células-tronco mesenquimais infectadas por lentivírus e gráficos da citometria de fluxo para quantificação de células GFP+

\subsection{Camundongos jovens possuem mais células-tronco hematopoéticas indiferenciadas quando comparados a camundongos idosos}

A caracterização imunofenotípica das células-tronco hematopoéticas murinas foi realizada por citometria de fluxo logo após o flush medular, os anticorpos monoclonais utilizados foram: Lineage (CD3e, CD11b, CD45R, TER-119, Ly-6G e Ly6C) - APC, Sca- PE-Cy7 , CD34 FITC e CD117-PE. Observamos que os camundongos jovens expressam significativamente mais células-tronco hematopoéticas 
indiferenciadas LSK (Lin-Ckit+Sca-1+) do que animais idosos. A percentagem de células LSK entre o grupo de camundongos jovens e grupo de camundongos idosos apresentou diferença significativa (valor-p 0,0153, Figura 30C), sugerindo que as populações de células-tronco hematopoéticas mais progenitoras diminuem com o envelhecimento. Nossa hipótese é que estas alterações podem ser causadas por mudanças no nicho medular.

A

Camundongos Jovens
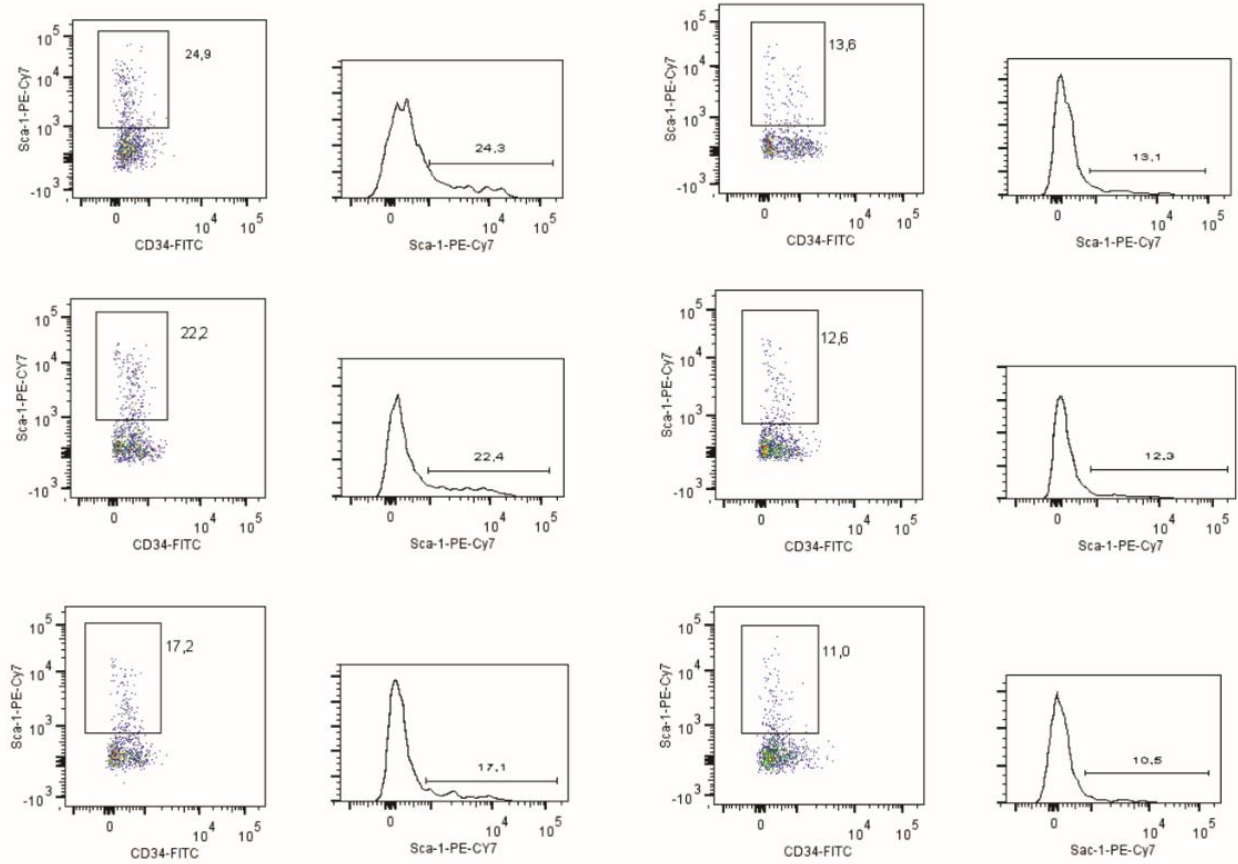
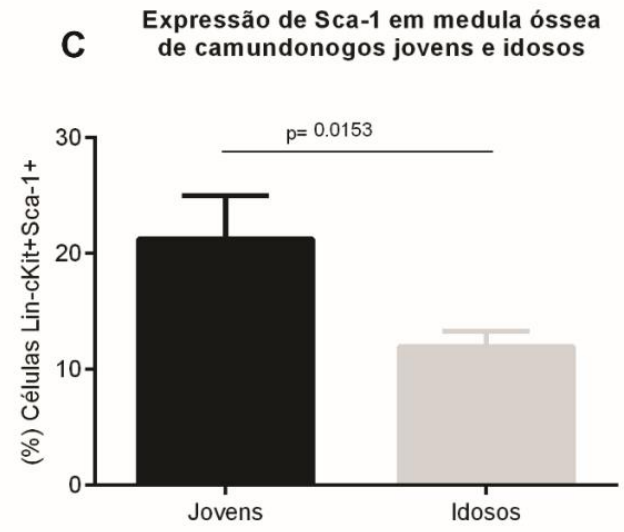

Células da $\mathrm{MO}$ de camundongos jovens e idosos foram isoladas e imunofenotipadas por citometria de fluxo quanto à ausência de expressão de Lineage (CD3e, CD11b, CD45R, TER-119, Ly-6G e Ly-6C) - APC, e presença de expressão de Sca- PE-Cy7, CD34 FITC e CD117-PE. Gráficos de pontos e histogramas mostrando a expressão de células LinCkit+Sca-1+ na medula óssea de (A) animais jovens (B) animais idosos. (C) Diferença significativa na percentagem de células Lin-Ckit+Sca1+ em animais jovens comparadas aos animais idosos $(n=3)$.

Figura 30. Análise de células Lin-Ckit+Sca1+em camundongos jovens e idosos 


\subsection{Avaliação da técnica de transplante de células-tronco mesenquimais - camundongos Rosa26/mTmG (Tomate')}

Para avaliar o transplante das CTMs - camundongos Rosa26/mTmG na $\mathrm{MO}$ dos camundongos selvagens Tomate, inoculamos PBS no fêmur esquerdo, como controle (Figura 31A), e $1 \times 10^{6}$ de CTMs Tomate ${ }^{+}$no fêmur direito de camundongo C57BL/6 (Figura 31B).

Após 3 horas do transplante, o camundongo foi sacrificado, os fêmures isolados e as células das medulas ósseas obtidas por meio de flush, seguindo de avaliação do mosaicismo das células fluorescentes vermelhas (Tomate+) transplantadas no camundongo selvagem. Utilizando a técnica de citometria de fluxo, as células foram avaliadas em relação a tamanho e granulosidade, posteriormente, por estratégia de gate, os eventos duplos foram excluídos e, por fim, a expressão da fluorescência da proteína vermelha tomate foi verificada nas células.

Podemos observar nos resultados da figura baixo, a presença das CTMs Rosa26/mTmG na frequência de $0,246 \%$ somente no fêmur em que as CTMs foram transplantadas. Este experimento piloto, portanto, nos assegura que o transplante das células foi realizado com eficiência.
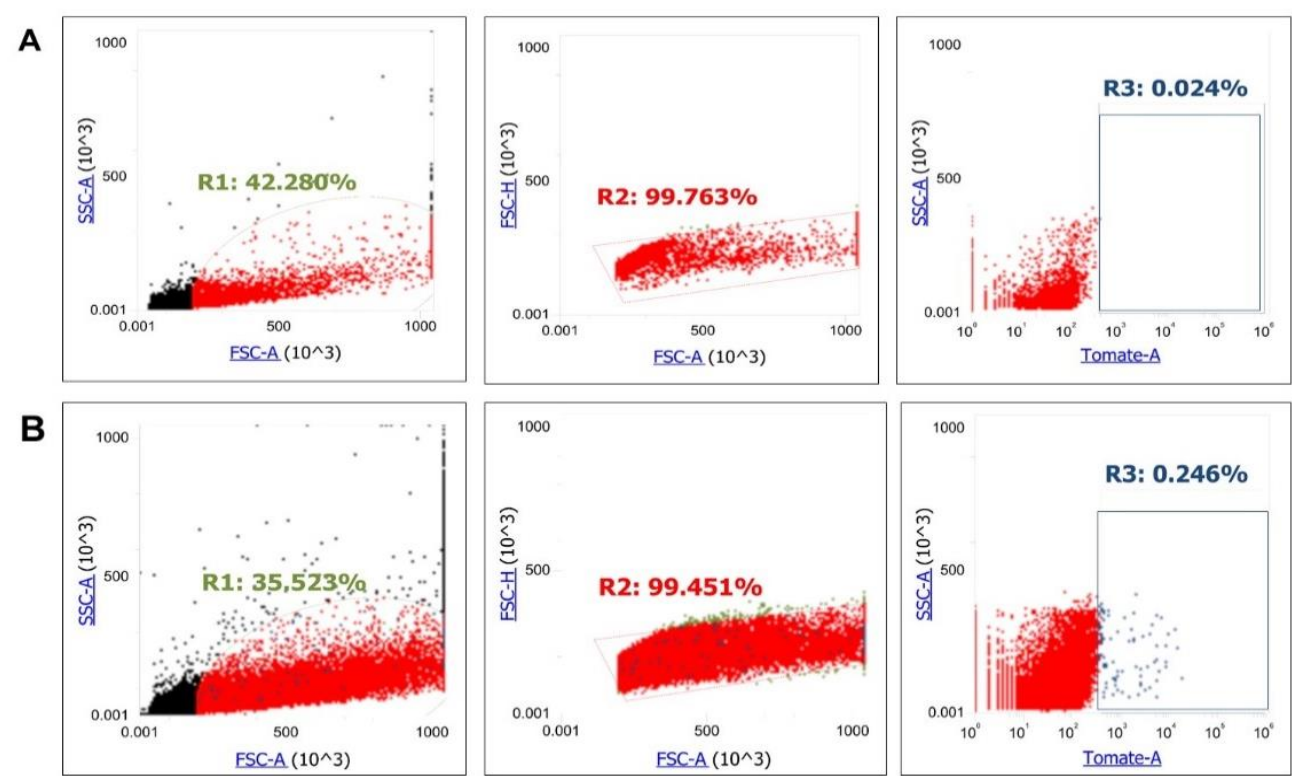

Análise por tamanho de granulosidade, análise dos eventos duplos e gráficos de pontos mostrando a expressão de CTMs Rosa26/mTmG (Tomate) (A) Injeção de PBS controle (B) Transplante de $1 \times 10^{6}$ de CTMs Rosa26/mTmG (Tomate ${ }^{+}$). $\mathrm{n}=3$.

Figura 31. Citometria de fluxo, avaliação da técnica de transplante de células-tronco mesenquimais murinas 


\section{DISCUSSÃO}

Compreender as alterações que ocorrem no nicho das células-tronco hematopoéticas é um passo importante para perspectivas mais adequadas de aplicações terapêuticas. Sabe-se que as CTMs residem na MO e são consideradas parte do nicho das CTHs, portanto, são células importantes na manutenção da homeostase dos nichos medulares. Nesse estudo, o foco principal foi a quimiocina CXCL12 produzida pelas CTMs e seu papel no processo de autorrenovação e diferenciação das célulastronco hematopoéticas.

Devido ao número limitado de células hematopoéticas sua expansão in vitro é particularmente relevante para ampliar suas aplicações terapêuticas, entretanto, a cultura de CTHs in vitro é frequentemente acompanhada por sua diferenciação. Considerando que o nicho hematopoético permite que as CTHs se autorrenovem, o desenvolvimento de plataformas de cultura celular capazes de imitar um microambiente do tipo nicho hematopoético poderia contribuir para manter a funcionalidade da CTH cultivado in vitro e ampliar o entendimento da interação entre CTHs e CTMs.

De fato, o conceito de nicho de CTHs foi proposto pela primeira vez por Schofield no final dos anos $1970^{(1)}$ e estudos de imagem descrevem a localização da CTH dentro do nicho medular sugerem que sua associação com o nicho é a chave para manter o seu estado quiescente. ${ }^{(14)}$ Embora os mecanismos envolvidos entre CTMs e CTHs não sejam totalmente compreendidos, a secreção de fatores solúveis, como por exemplo, SCF e a quimiocina CXCL12 parecem estar envolvidos na autorrenovação de CTHs. ${ }^{(4,64,70,74,77,144,145)}$

Nos organismos multicelulares, a diferenciação celular é frequentemente precedida pela divisão celular, este é certamente o caso da hematopoese, onde a diferenciação das CTHs ocorre após a ativação do ciclo celular, ${ }^{(146)}$ entretanto, quais os sinais levam as CTHs a se autorrenovar ou que promovem a sua diferenciação ainda permanece pouco compreendido. ${ }^{(147)}$

Alguns autores postulam que nichos distintos na $\mathrm{MO}$ regulam destinos diferentes para a CTH. Tamplin et al. através de um repórter transgênico específico de CTHs em peixe-zebra, realizou imagens de alta resolução e demonstrou interações importantes entre CTHs e seu nicho. Quando as CTHs chegam ao nicho perivascular, um grupo de células endoteliais se remodelam para formar um ambiente semelhante a 
um bolso, as células endoteliais envolvem uma única CTH ligada a uma única célula estromal. A imagem mostrou que o estroma ancora as CTHs e orientam suas divisões e expansões na idade adulta, demonstrando evidências para interações dinâmicas no nicho. ${ }^{(148)}$

As análises do nosso estudo se basearam em estudos anteriores de análise de transcriptoma que indicaram que genes associados à especificação de linhagem mieloide, bem como genes associados a malignidades mieloides eram expressos em CTHs durante o processo de envelhecimento. ${ }^{(104,106,107,149)}$

O conhecimento sobre os vários aspectos do envelhecimento de CTHs são obtidos por estudos em modelos murinos de envelhecimento e que em grande parte ainda não foi validado em seres humanos. Recentemente, Hennrich et al. realizaram analises do proteoma de CTHs humanas, e demonstraram que marcadores de linhagem linfoide, tais como CD10, IKZF1 (família ikaros) e o fator EBF1 (Early B-Cell Factor 1) também diminuem com o avanço da idade. (150)

Anteriormente também foi demonstrado por nosso grupo,(118) que a secreção de CXCL12 pelas células estromais envelhecidas está dimuida e é um ponto relevante envolvendo mudanças no nicho de CTHs. Recentemente, mudanças relacionadas ao envelhecimento em camundongos também foi associada à diminuição da expressão de CXCL12, SCF e Jagged.(119)

Em etapa prévia a este projeto, foi analisada a localização das CTHs nos poços de cultura e o quanto as CTMs influenciavam a manutenção e os parâmetros fenotípicos de CTHs. Observou-se que as CTHs estavam em duas localizações distintas, em suspensão no sobrenadante (S) ou aderidas (A) a superfície das CTMs no poço de cultura. As que estavam aderidas apresentavam fenótipo mais imaturo, sugerindo que a manutenção das CTHs em estado mais indiferenciado é dependente de contato com as CTMs. ${ }^{(118)}$

Estes resultados estão de acordo com os dados reportados nos trabalhos de Alakel et al. e Jing et al., os quais sugerem a influência do contato célulacélula no perfil mais imaturo das CTHs. ${ }^{(151,152)}$ Entretanto, para realização da extração do RNA foi utilizado somente a fração de CTHs que estavam no sobrenadante, o que pode explicar a maior expressão para os genes relacionados à diferenciação.

Ainda na etapa anterior a este projeto, durante a análise dos parâmetros fenotípicos das CTHs, os ensaios de cocultivo de CTHs com CTMs realizados de diferentes faixas etárias, foram observadas diferenças significativas após 
sete dias de cultivo nas CTHs da fração A, quando cultivadas com CTMs mais jovens (020 anos), devido a maior percentagem de células Lin- CD34+ nesta fração, no grupo de 21-40 anos a percentagem de células progenitoras primitivas e intermediárias foi maior tanto na fração S quanto na A. Sugerindo que CTHs em contado com CTMs de doadores mais jovens são mantidas com fenótipo mais indiferenciado, nos grupos 41-60 anos e > 61 anos não foram observadas diferenças significativas. ${ }^{(118)}$

$\mathrm{Na}$ etapa atual deste projeto, a expressão gênica foi avaliada em CTHs previamente cocultivadas com CTMs de indivíduos que variaram entre 22 e 48 anos, e o cocultivo nos permitiu avaliar e corroborar dados anteriores do grupo sobre o papel das CTMs sobre as CTHs. Neste contesto, além do aumento na expressão dos genes relacionados à diferenciação de linhagens hematopoéticas (Apêndice 1, Figura 1), as análises de expressão gênica nas CTHs para fatores de transcrição associados à autorrenovação mostrou que após sete dias de cocultivo ocorreu queda significativa na expressão do fator de transcrição POU5F1 (valor-p <0,0001), em contrapartida, houve aumento significativo na expressão gênica de KLF4 (valor-p 0,0037) após sete e doze dias (valor-p 0,0459) de cocultivo com células-tronco mesenquimais. $O$ fator de transcrição KLF4 foi descrito no processo de autorrenovação e pluripotência e pode estar envolvido na diferenciação das CTHs para a linhagem mieloide, pois este fator de transcrição também está envolvido no mecanismo de diferenciação mieloide, este achado está de acordo com Kurotaki et al. ${ }^{(42,153)}$

Observamos também que após sete dias de cocultivo, houve aumento significativo na expressão gênica da proteína $\beta$-catenina (valor-p 0,0166) nas CTHs, proteína envolvida na vida de sinalização Wnt canônico ${ }^{(94)}$ embora o papel da via Wnt na manutenção de CTH permaneça não resolvido. Novos estudos com células estromais perivasculares no nicho medular humano devem ser desenvolvidos para auxiliar o esclarecimento do papel da Wnt no nicho. Todavia, um estudo em camundongos demonstrou que baixos níveis de sinalização favoreceram a via Wnt canônica, levando a manutenção de um fenótipo imaturo e aumento da capacidade de repopulação de CTH, em oposição a níveis moderados e altos de sinalização de Wnt, que prejudicou a capacidade de repopulação das CTHs. ${ }^{(154)}$ Quando ocorre a perda completa da sinalização de Wnt ocorre diminuição de autorrenovação, ${ }^{(4)}$ demonstrando que CTHs são altamente sensíveis aos níveis de Wnt, o que deve ser considerado quando se pensar em uma potencial tradução clínica. 
Zhou utilizando uma plataforma de cocultura usando transwell, avaliou as interações parácrinas de células mononucleares da MO humana com células-tronco mesenquimais e, demonstrou efeitos parácrinos entre essas células através de fatores solúveis, tais como a via da Wnt. Neste estudo a expressão gênica de células hematopoéticas humanas e CTMs revelaram as convergências e divergências na expressão gênica relacionada à Wnt, os dados mostraram que Wnt1, 4, 6, 7a e 10a são predominantemente expressas apenas em células monocucleares, já Wnt 2, 7b, 5a e 5b são principalmente expressas em CTMs; e as Wnt 3, 10b, 11, 13 e 14, são expressas em ambos. As células mononucleares expressam inibidores de Wnt e secretaram o peptídeo relacionado a Frizzled (sFRP) -3 e -5. ${ }^{(155)}$ Sendo assim, corroborando os nossos dados, estes resultados ressaltam a participação da via Wnt na comunicação entre esses dois grupos de células.

Portanto, o cultivo de CTHs em presença das CTMs mostrou contribuir para o aumento da expressão gênica de fatores de transcrição relacionados à diferenciação para várias linhagens hematopoéticas, assim como para aumento na expressão da proteína $\beta$-catenina. Entretanto, em contrapartida diminuiu, ou não contribuiu para a maioria dos genes relacionados à pluripotência analisados.

Acreditamos que estes genes possam ser estimulados pelo secretoma durante a função parácrina das células-tronco mesenquimais, mas também por contato célula-célula, uma vez que o cocultivo foi realizado por contato direto, ou seja, sem nenhum tipo de separação entre os dois tipos de células.

Diante disto, podemos refletir também sobre as limitações do cocultivo 2-D, uma vez que o comportamento de CTHs não é modulado apenas por um coquetel específico de citocinas, mas também por uma arquitetura 3-D fornecida pelo ambiente celular presente na MO. De fato existe a importância de um microambiente de cocultivo CTH/CTM 3-D para modular a atividade do CTH. ${ }^{(151,156)}$ Alguns estudos têm hipotetizado que a cultura de CTM como esferóides 3-D poderia contribuir para mimetizar interações do nicho da MO. ${ }^{(157,158)}$ Porém, Futrega et al., demonstraram que baixas concentrações exógenas de citocinas em cocultura 2D ou 3D de CTM melhorou modestamente os resultados gerais de expansão de células hematopoéticas e células $\mathrm{CD}^{2} 4^{+}$, em contraste, um aumento substancial no rendimento de células CD34+CD38- foi observado em culturas, independentemente da presença de CTMs. ${ }^{(158)}$ Enquanto culturas com CTMs estão surgindo como abordagens alternativas, as principais mudanças nas características celulares durante a formação de esferoides 3D permanecem incertas. 
Recentemente, foi demonstrado que estímulo mediado por miRNA em CTMs 2D foi suficiente para imitar a atividade aprimorada de nicho de esferoides de CTMs 3D. (159) Portanto, apesar do amplo uso de CTMs para suporte parácrino em ensaios clínicos, sua atividade de suporte é variável e heterogênea e apresenta grandes desafios.

Sendo assim, considerando que vários mecanismos foram estudados em algumas poucas populações celulares que constituem a MO, a compreensão dos papéis dos mecanismos intrínsecos versus extrínsecos das CTHs no nicho medular, permanece incompleta. Hennrich et al., publicaram mecanismos moleculares envolvidos no envelhecimento das CTHs humanas, bem como de outras populações de células do nicho medular, realizaram uma análise proteômica quantitativa abrangente das CTHs e seu nicho em uma grande coorte de indivíduos de diferentes faixas etárias, seus resultados mostraram que CXCL12, molécula adesão de células vasculares 1 VCAM1 (vascular cell adhesion molecule-1) e fibronectina (FN1), diminuíram em CTMs de idosos, ${ }^{(150)}$ corroborando resultados anteriores do nosso grupo que também demonstraram a diminuição da quimiocina CXCL12 no perfil secretório de células-tronco mesenquimais em indivíduos acima de 60 anos. ${ }^{(118)}$

Portanto, para investigar qual a participação da quimiocina CXCL12 no perfil das CTHs, realizamos a expansão in vitro das CTHs com e sem tratamento de CXCL12. O percentual de CTHs foi comparado entre o grupo controle e grupo tratado com CXCL12, e houve aumento significativo na quantidade de células com perfil mais indiferenciado CD34+ CD38- que receberam o tratamento de CXCL12 durante 7 dias (valor-p 0,0303). Embora o subtipo CD34+D38- defina populações primitivas na MO e no sangue do cordão umbilical, existem diferenças funcionais dependendo da origem das células. As células do sangue do cordão umbilical CD34+ CD38- mostraram maior eficiência de clonagem, proliferação mais rápida em resposta ao de estímulo de citocinas e maior número de clones do que a MO.(160-163)

McKenzie et al. demonstraram que a expressão de antígeno CD38 não é contínuo na hierarquia hematopoética, mas tem uma alta taxa de expressão em interações célula-célula, as células CD34+ CD38+ possuem a capacidade de repopulação celular e produção de progenitores de curto termo. ${ }^{(164)}$ Portanto, podemos sugerir que a presença de CXCL12 tenha uma função importante na "repopulação" dos progenitores hematopoéticos, podendo assim, contribuir para manutenção do estoque de célulastronco hematopoéticas mais progenitoras no nicho medular. 
Seguindo na busca por esclarecer o impacto da quimiocina CXCL12 nas células-tronco hematopoéticas $\mathrm{CD}_{3} 4^{+}$, após sete dias de cultivo com e sem tratamento de CXCL12, foi analisado a expressão gênica dos genes dos fatores de transcrição ligados à diferenciação de linhagem hematopoética, a expressão gênica de PU.1 (valor-p 0,0001), GATA2 (valor-p 0,0015) e IKZF1 (valor-p 0,0010) tiveram diminuição significativa em suas expressões nas CTHs cultivadas com a quimiocina CXCL12 quando comparados ao controle. Os fatores PU.1 e GATA2 estão associados à diferenciação mieloide, ${ }^{(40,49,128,129)}$ enquanto que IKZF1 (Ikaros) e GATA3 estão relacionados à diferenciação linfoide. ${ }^{(130-134)}$ Com exceção do POU5F, HOXB4 e NOTCH1, os outros fatores de transcrição ligados a autorrenovação, KLF4 (valor-p 0,0358), NANOG (valor-p 0,0153), SOX2 (valor-p 0,0078) tiveram aumento significativo de expressão gênica nas células cultivadas na presença de CXCL12.

Corroborando nossos dados de expressão gênica, onde os fatores de transcrição de especificação de linhagem interagem entre si e inclusive com fatores de transcrição relacionados à fase embrionária, Goode et al., investigaram o processo da via de desenvolvimento nos estágios sequenciais entre células-tronco embrionárias e especificação hematopoiética. Eles analisaram a expressão gênica, acessibilidade da cromatina, modificação de histonas, e FTs, os dados revelaram a regulação dos elementos que dirigem a expressão diferencial de genes e também o mecanismo de ligação ao FT. Neste trabalho eles realizaram a diferenciação in vitro de células-tronco embrionárias de camundongos até macrófagos, mapeando os estágios de diferenciação através de um gene repórter GFP e marcadores proteicos de superfície. Para capturar padrões de expressão dinâmica em toda via de desenvolvimento eles correlacionaram essas mudanças com alterações na estrutura da cromatina e ligação de FT, identificaram 31 principais grupos de expressão, representando diferentes categorias de ontologia genética. ${ }^{(165)}$

Os resultados de Goode et al. criaram a proposta de que promotores equilibrados de genes reguladores chaves são mantidos até o início do desenvolvimento, mas mudam de estados equilibrado para estados ativo ou reprimido, a ligação precoce de LMO2 e TAL1 é altamente significativa em elementos reguladores nos hemangioblastos $(\mathrm{HB})$, endotélio hemogênico $(\mathrm{HE})$ e nos progenitores hematopoéticos (HPs), a ligação de PU.1 mostra sobreposição significativa nos progenitores hematopoéticos, além disso, os resultados demonstraram também que PU.1 pode regular as principais regiões específicas para macrófagos já no início dos progenitores 
multipotentes, dando peso à descoberta de que é capaz de interagir com a cromatina. ${ }^{(165-}$ 169)

Os resultados de Goode et al., demonstraram também que nas células-tronco embrionárias, todos os FTs de pluripotência participam de um ambiente altamente conectado, principalmente Nanog, POU5F1 e SOX2 e, ainda nesta fase ligamse a loci para FTs hematopoéticos, incluindo Elk4, Gata2, Lmo2, Meis1, Runx1 e Tal1, que exibem cromatina aberta ou pronta para seus promotores, mas também vinculam Gfi1b, Gata1 e Spi1, cujos promotores estão organizados em cromatina fechada ou reprimida. ${ }^{(165)}$ Ainda no trabalho de 2016, Goode et al. mostram que desde o estágio do $\mathrm{HB}$, vários genes reguladores hematopoéticos também são regulados, incluindo Tal1 e Lmo2, que exibem auto-regulação e co-regulam múltiplos genes, o estágio HP mostra a expressão mais alta para muitos dos principais FTs hematopoéticos, com eventos de ligação complexos e combinatórios, inclusive mostram interação com um dos fatores de pluripotência, como o SOX2, regulando-o e mantendo sua expressão reprimida. Os resultados demonstram ainda que SOX2 pode sofrer intervenção dos FTs hematopoéticos. ${ }^{(165)}$ Portanto, esses dados corroboram nossos achados, onde o estímulo com a quimiocina CXCL12 diminuiu a expressão de PU.1 (valor-p 0,0001) e ao mesmo tempo aumento a expressão de SOX2 (valor-p 0,0078), com indícios de que ocorra interação entre a regulação desses genes. Entretanto, a complexidade dos mecanismos moleculares, e o perfil de expressão específico de cada tipo de célula e os mecanismos dessa progressão dinâmica permanecem em grande parte obscuros. Devido à falta de informações mais abrangentes sobre a ligação do TF e a dinâmica da cromatina, de como eles interagem e como ocorre o controle transcricional e se há participação de sinalização extrínseca como da CXCL12, não é possível concluir que seja este o mecanismo identificado nos nossos experimentos.

Diante dos resultados do perfil de expressão gênica e com os resultados do fenótipo das CTHs, podemos afirmar que a CXCL12 pode prevenir a diferenciação das CTHs in vitro, uma vez que diminui a expressão de fatores de transcrição de linhagens hematopoéticas e aumenta a expressão dos fatores de transcrição ligados a pluripotência nestas células. Corroborando dados da literatura, onde CTHs de camundongos cultivadas in vitro na presença de CXCL12 tornaram-se mais quiescentes. ${ }^{(90,91)}$ Deve-se notar que os estudos in vitro sobre a quiescência de CTHs são difíceis de interpretar, considerando diferenças entre microambiente da $\mathrm{MO} e$ as culturas in vitro. ${ }^{(147)}$ 
Outro estudo demonstrou in vivo, demonstrou que a células estromais CXCL12+ podem orientar o plano de divisão das CTHs, fornecendo um sinal de polarização e, que a maioria das divisões tinham uma orientação distinta: uma célula filha permaneceu próxima à célula estromal e a outra célula filha ficava deslocada para longe da nicho, esses resultados sugerem que células estromais que secretam CXCL12 contribuem para o controle da divisão assimétrica. ${ }^{(148)}$

Recentemente, Lee et al. mostraram novamente o envolvimento da CXCL12 no processo de envelhecimento, relataram que as CTMs provenientes de MO de camundongos em fase neonatal expressaram níveis mais altos de CXCL-12 e Jagged-1, em relação à CTMs de MO adultas, corroborando nossos dados. Este estudo também demostrou que camundongos tratados com inibidores de CXCL-12 e Jagged-1 (AMD3100 e DAPT, respectivamente) causaram diminuição significativa dos progenitores hematopoéticos na $\mathrm{MO}$, e a inibição de Jagged-1 diminuiu autorrenovação in vitro das células progenitoras ${ }^{(119)}$ o que está de acordo com observações anteriores. ${ }^{(170)}$ Lee et al., concluíram com esses resultados que o microambiente neonatal da MO pode ser composto por maior diversidade de subtipos CTM primitivas que expressam moléculas de sinalização que podem suportar melhor a autorrenovação de CTHs quando comparadas com CTMs derivadas de MO adulta. ${ }^{(119)}$

Com base na literatura, nós também apoiamos a ideia de que existam subpopulações de células-tronco mesenquimais que contribuam de forma diferente para o nicho das células-tronco hematopoéticas, sendo assim, realizamos testes para padronizar e verificar marcadores de CTMs que primeiramente caracterize subpopulações e que contribuam com moléculas de sinalização, mais especificamente a quimiocina CXCL12. Inicialmente tentamos isolar através a técnica de sorting subpopulações de CTMs que a literatura descreve como importantes para a secreção no nicho medular de quimiocina CXCL12, como por exemplo, o marcador NG2. ${ }^{(75,77)}$ Entretanto, após inúmeras tentativas não obtivemos sucesso, após a separação celular, as células durante o cultivo voltavam a apresentar o perfil inicial. (Apêndice 4 e 5, Figuras 4 e 5).

Sendo assim, mudamos nossa abordagem técnica e seguimos para a técnica de silenciamento gênico utilizando RNA siRNA, o objetivo final é avaliar a curva de diferenciação de CTHs após o cocultivo com CTMs submetidas ao tratamento com siRNA-CXCL12, para observamos a função da quimiocina CXCL12 especificamente secretada por CTMs. Durante a padronização da técnica, foi observado queda da 
expressão gênica remanescente em 2 dias após o silenciamento, seguido também de queda da expressão proteica intracelular em 3 dias após o silenciamento. Entretanto o silenciamento com siRNA-CXCL12 não foi suficiente para diminuir significativamente a expressão proteica secretada ou intracelular da quimiocina CXCL12, além disso, após esse período apresentou aumento compensatório de expressão gênica e proteica.

Portanto, observamos que o silenciamento por siRNA mostrou-se transitório e insuficiente para o nosso objetivo, sendo assim, partimos para outra técnica de silenciamento que nos possibilita um silenciamento mais duradouro ou permanente. Dessa forma, iniciamos a padronização de transdução com lentivírus para o silenciamento do mRNA da quimiocina CXCL12 utilizando shRNA.

A literatura relata muitos desafios e diversos trabalhos mostrando a dificuldade de otimização das técnicas de transfecção e transdução das CTMs, ${ }^{(137,139,140,171-174)}$ apesar do efeito de silenciamento muito transitório do siRNA, o agente de transfecção $\operatorname{siPOR}^{\circledast} N e o F x^{\mathrm{TM}}$ e a técnica de transfecção reversa mostrou eficiência na entrega do siRNA e não causou danos as células.

Em relação ao silenciamento utilizando plasmídeo (shRNA), também encontramos desafios; 1 - o reagente de transfecção siPORT ${ }^{\circledR} N e o F x^{\mathrm{TM}}$ não foi eficiente neste caso, então decidimos seguir para infecção com lentivírus; 2- uso de polibrene, trabalhos relatam o uso de polibrene para facilitar a entrada do vírus nas CTMs, ${ }^{140,141)}$ porém, também existem relatos que isto pode retardar a proliferação celular e pode induzir senescência, ${ }^{(142,143)}$ o primeiro teste sem polibrene não houve nenhum ou pouco sinal de transdução, os testes com o polibrene conforme a literatura sugere $(8 \mu \mathrm{g} / \mathrm{mL})^{(140,141)}$ e a exposição por 24 horas trouxeram resultados satisfatórios, mas acima deste período as células diminuem a capacidade de proliferação; 3- padronização da concentração de células, notamos que a confluência celular no momento da infecção é um processo crítico, por isso, a concentração de células deve ser próxima a 5.200 células $/ \mathrm{cm}^{2}$ e para não comprometermos a confluência, optamos realizar a infecção com as células em suspensão.

Dessa forma, utilizando um constructo de plasmídeo contendo um shRNA controle e promotor padrão de citomegalovírus que dirige a expressão da proteína GFP, o resultado obtido até o presente momento para transdução em CTMs humanas é de $94 \%$, acima do que foi relatado em alguns estudos, ${ }^{(137,171,175)}$ portanto, o próximo passo é iniciar os testes de padronização do silenciamento. 
Neste interim, iniciamos os estudos em camundongos, foi coletado a MO de 14 camundongos entre machos e fêmeas, com 4-60 semanas de idade, sendo separados em grupos de jovens com até 24 semanas e grupos mais velhos entre 56 e 60 semanas. Avaliamos a imunofenotipagem de CTHs entre esses dois grupos, a percentagem de células LSK entre o grupo de camundongos jovens e grupo de camundongos idosos, mostrou que os camundongos jovens têm maior número de células indiferenciadas quando comparados aos idosos. Alterações funcionais que ocorrem nas CTHs com o avanço da idade foram comumente atribuídas ao envelhecimento celular. De acordo com este modelo, as propriedades funcionais de CTHs diminuem gradualmente como resultado de um acúmulo de dano celular, como o acúmulo de lesões no DNA ${ }^{(176-178)}$ ou desregulação epigenética. ${ }^{(179,180)}$ Contudo, a identificação de populações de CTHs intrinsecamente influenciados por linhagem(181) sugeriu um modelo diferente no qual a composição clonal do estoque de CTHs de camundongos idosos seja funcionalmente equivalente a seus pares, principalmente pelo aumento relativo da linhagem mieloide dominante. ${ }^{(182-184)}$

Embora esses modelos não sejam mutuamente exclusivos, determinar seu respectivo significado é um passo vital para um entendimento completo dos mecanismos subjacentes. Dykstra et al. projetaram experimentos para avaliar várias propriedades de CTHs purificadas e isoladas da MO de camundongos jovens e idosos, revelam que uma população de CTHs predominantemente mieloides dominantes se acumulam com a idade e que CTHs dos camundongos idosos são funcionalmente inferiores aos jovens em vários parâmetros, incluindo uma menor funcionalidade in vitro e in vivo, como por exemplo, uma resposta de proliferação atrasada em coculturas com células estromais, uma eficiência reduzida para homing após transplante e uma atividade de autorrenovação in vivo de longo prazo reduzida. Além disso, demonstraram evidências de que o repovoamento in vivo com perfil de CTHs envelhecidas pode ser gerado a partir de CTHs jovens ao longo de um curso prolongado de um transplante, sugerindo que existe contribuição do microambiente medular. ${ }^{(106)}$

Portanto, para dar início a avaliação da contribuição do microambiente medular para as alterações durante o envelhecimento em murinos, após a avaliação da imunofenotipagem de CTHs de MO de camundongos jovens e idosos, seguiremos para o transplante de células-tronco mesenquimais dos mesmos, o objetivo principal é que no futuro façamos a avaliação de um modelo in vivo de envelhecimento, visto que existe a dificuldade de obtenção de MO humana de indivíduos idosos e correlacionar este modelo 
in vivo com a papel da quimiocina CXCL12 na manutenção das células-tronco hematopoéticas. 


\section{CONCLUSÕES}

1. O tratamento com CXCL12 contribuiu para manter o estado mais indiferenciado das células-tronco hematopoéticas assim como aumentou a expressão de genes relacionados à multipotência, a expressão da proteína $\beta$-catenina e diminuiu a expressão de genes de diferenciação nestas células;

2. O cocultivo de células-tronco mesenquimais e céulas-tronco hematopoéticas, pode contribuir para o aumento da expressão genes relacionados à diferenciação, aumento na expressão gênica da proteína $\beta$-catenina, mas sem impacto nos genes relacionados à multipotência nas células-tronco hematopoéticas;

3. As subpopulações de células-tronco mesenquimais isoladas utilizando a técnica de sorting com os marcadores $\mathrm{NG} 2^{\text {high }} \mathrm{CD} 90^{\text {high }} / \mathrm{NG} 2^{\text {low }} \mathrm{CD} 90^{\text {low }}$ ou NG2 ${ }^{\text {high }} \mathrm{CD} 10^{\text {high}} / \mathrm{NG} 2^{\text {low }} \mathrm{CD} 10^{\text {low }}$ voltam a apresentar o fenótipo prévio quando colocadas novamente em cultura;

4. Os resultadas da técnica de silenciamento gênico para a quimiocina CXCL12 por siRNA em células-tronco mesenquimais revelou ter efeito transitório, além de efeito compensatório após o silenciamento, aumentando ainda mais os níveis da proteína e mRNA da quimiocina CXCL12;

5. Os camundongos Rosa26/mTmG mais velhos exibiram quantidades reduzidas de células-tronco hematopoéticas do tipo Lin-Ckit+Sca-1+ na medula óssea em comparação com o grupo de camundongos Rosa26/mTmG jovens. 
Anexo 1. Parecer do CEP

\section{PARECER CONSUBSTANCIADO DO CEP}

\section{DADOS DO PROJETO DE PESQUISA}

Título da Pesquisa: Potencial influência do envelhecimento das células-tronco mesenquimais na autorenovação, diferenciação e multipotência de células-tronco hematopoéticas.

Pesquisador: Luciana Cavalheiro Marti

Área Temática:

Versão: 3

CAAE: 21840113.0 .0000 .0071

Instituição Proponente: Hospital Israelita Albert Einstein-SP

Patrocinador Principal: Hospital Israelita Albert Einstein-SP

\section{DADOS DO PARECER}

Número do Parecer: 506.071

Data da Relatoria: 04/02/2014

\section{Apresentação do Projeto:}

Envio da Emenda 3 incluindo informações adicionais no Termo de Consentimento Livre e Esclarecido, em resposta a solicitação da Instituição co-participante FM-USP.

Objetivo da Pesquisa:

Aprovação do Termo de Consentimento Livre e Esclarecido Versão 3 de 13 de Dezembro de 2013.

Avaliação dos Riscos e Benefícios:

Não se aplica

Comentários e Consideraçóes sobre a Pesquisa:

Protocolo de Pesquisa já aprovado pelo CEP/Einstein em reunião realizada em 29 de Outubro de 2013.

\section{Consideraçōes sobre os Termos de apresentação obrigatória:}

Termo de Consentimento Livre e Esclarecido contendo informações adicioanis que não alteram o delineamento e a base ética do estudo.

\section{Recomendações:}

Não há.

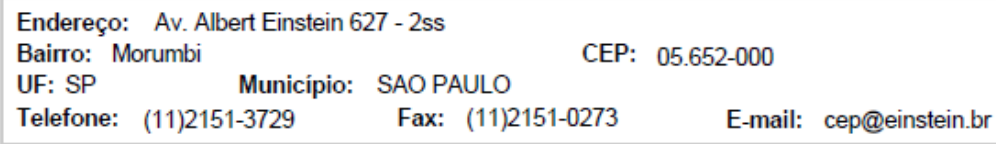


Continuação do Parecer: 506.071

Conclusöes ou Pendências e Lista de Inadequaçōes:

Aprovado Termo de Consentimento Livre e Esclarecido Versão 3 de 13 de Dezembro de 2013.

Situação do Parecer:

Aprovado

Necessita Apreciação da CONEP:

Não

Considerações Finais a critério do CEP:

Emenda aprovada pelo CEP/Einstein em regime Ad-Referendum.

SAO PAULO, 02 de Janeiro de 2014

Assinador por:

Fabio Pires de Souza Santos

(Coordenador) 


\section{REFERÊNCIAS}

1. Schofield R. The relationship between the spleen colony-forming cell and the haemopoietic stem cell. Blood Cells. 1978;4(1-2):7-25.

2. Levesque JP, Helwani FM, Winkler IG. The endosteal 'osteoblastic' niche and its role in hematopoietic stem cell homing and mobilization. Leukemia. 2010;24(12):1979-92.

3. Anthony BA, Link DC. Regulation of hematopoietic stem cells by bone marrow stromal cells. Trends Immunol. 2014;35(1):32-7.

4. Mendelson A, Frenette PS. Hematopoietic stem cell niche maintenance during homeostasis and regeneration. Nat Med. 2014;20(8):833-46.

5. Hanoun M, Frenette PS. This niche is a maze; an amazing niche. Cell Stem Cell. 2013;12(4):391-2.

6. Omatsu Y, Nagasawa T. The critical and specific transcriptional regulator of the microenvironmental niche for hematopoietic stem and progenitor cells. Curr Opin Hematol. 2015;22(4):330-6.

7. Richter R, Forssmann W, Henschler R. Current developments in mobilization of hematopoietic stem and progenitor cells and their interaction with niches in bone marrow. Transfus Med Hemother. 2017;44(3):151-64.

8. Pinho S, Frenette PS. Haematopoietic stem cell activity and interactions with the niche. Nat Rev Mol Cell Biol. 2019;20(5):303-20.

9. Orkin SH, Zon LI. Hematopoiesis: an evolving paradigm for stem cell biology. Cell. 2008;132(4):631-44.

10. Wilson A, Murphy MJ, Oskarsson T, Kaloulis K, Bettess MD, Oser GM, et al. c-Myc controls the balance between hematopoietic stem cell self-renewal and differentiation. Genes Dev. 2004;18(22):2747-63.

11. Nombela-Arrieta C, Pivarnik G, Winkel B, Canty KJ, Harley B, Mahoney JE, et al. Quantitative imaging of haematopoietic stem and progenitor cell localization and hypoxic status in the bone marrow microenvironment. Nat Cell Biol. 2013;15(5):533-43.

12. Nilsson SK, Johnston HM, Coverdale JA. Spatial localization of transplanted hemopoietic stem cells: inferences for the localization of stem cell niches. Blood. 2001;97(8):2293-9.

13. Kiel MJ, Yilmaz OH, Iwashita T, Yilmaz OH, Terhorst C, Morrison SJ. SLAM family receptors distinguish hematopoietic stem and progenitor cells and reveal endothelial niches for stem cells. Cell. 2005;121(7):1109-21.

14. Mendez-Ferrer S, Michurina TV, Ferraro F, Mazloom AR, Macarthur BD, Lira SA, et al. Mesenchymal and haematopoietic stem cells form a unique bone marrow niche. Nature. 2010;466(7308):829-34.

15. Sugiyama $T$, Kohara $H$, Noda $M$, Nagasawa $T$. Maintenance of the hematopoietic stem cell pool by CXCL12-CXCR4 chemokine signaling in bone marrow stromal cell niches. Immunity. 2006;25(6):977-88. 
16. Chotinantakul K, Leeanansaksiri W. Hematopoietic stem cell development, niches, and signaling pathways. Bone Marrow Res. 2012;2012:270425.

17. Yamamoto R, Morita Y, Ooehara J, Hamanaka S, Onodera M, Rudolph KL, et al. Clonal analysis unveils self-renewing lineage-restricted progenitors generated directly from hematopoietic stem cells. Cell. 2013;154(5):1112-26.

18. Cheng $\mathrm{H}$, Zheng $\mathrm{Z}$, Cheng $\mathrm{T}$. New paradigms on hematopoietic stem cell differentiation. Protein Cell. 2020;11(1):34-44.

19. Palis J, Yoder MC. Yolk-sac hematopoiesis: the first blood cells of mouse and man. Exp Hematol. $2001 ; 29(8): 927-36$.

20. Starnes LM, Sorrentino A. Regulatory circuitries coordinated by transcription factors and microRNAs at the cornerstone of hematopoietic stem cell self-renewal and differentiation. Curr Stem Cell Res Ther. 2011;6(2):142-61.

21. Faloon P, Arentson E, Kazarov A, Deng CX, Porcher C, Orkin S, et al. Basic fibroblast growth factor positively regulates hematopoietic development. Development. 2000;127(9):193141.

22. Winnier G, Blessing M, Labosky PA, Hogan BL. Bone morphogenetic protein-4 is required for mesoderm formation and patterning in the mouse. Genes Dev. 1995;9(17):2105-16.

23. Lee CY, Vogeli KM, Kim SH, Chong SW, Jiang YJ, Stainier DY, et al. Notch signaling functions as a cell-fate switch between the endothelial and hematopoietic lineages. Curr Biol. 2009;19(19):1616-22.

24. Kataoka H, Hayashi M, Nakagawa R, Tanaka Y, Izumi N, Nishikawa S, et al. Etv2/ER71 induces vascular mesoderm from Flk1+PDGFRa+ primitive mesoderm. Blood. 2011;118(26):6975-86.

25. Lee D, Park C, Lee H, Lugus JJ, Kim SH, Arentson E, et al. ER71 acts downstream of BMP, Notch, and Wnt signaling in blood and vessel progenitor specification. Cell Stem Cell. 2008;2(5):497-507.

26. Kallianpur AR, Jordan JE, Brandt SJ. The SCL/TAL-1 gene is expressed in progenitors of both the hematopoietic and vascular systems during embryogenesis. Blood. 1994;83(5):1200-8.

27. Lancrin C, Sroczynska P, Stephenson C, Allen T, Kouskoff V, Lacaud G. The haemangioblast generates haematopoietic cells through a haemogenic endothelium stage. Nature. 2009;457(7231):892-5.

28. Cheshier SH, Morrison SJ, Liao X, Weissman IL. In vivo proliferation and cell cycle kinetics of long-term self-renewing hematopoietic stem cells. Proc Natl Acad Sci U S A. 1999;96(6):3120-5.

29. Antonchuk J, Sauvageau G, Humphries RK. HOXB4 overexpression mediates very rapid stem cell regeneration and competitive hematopoietic repopulation. Exp Hematol. $2001 ; 29(9): 1125-34$.

30. Abramovich $\mathrm{C}$, Pineault N, Ohta H, Humphries RK. Hox genes: from leukemia to hematopoietic stem cell expansion. Ann N Y Acad Sci. 2005;1044(1):109-16. 
31. Wilkinson AC, Göttgens B. Transcriptional regulation of haematopoietic stem cells.In: Hime G., Abud H. (eds). Transcriptional and translational regulation of stem cells. Advances in experimental medicine and biology. Dordrecht: Springer; 2013. v.786, p. 187-212.

32. Burns CE, Traver D, Mayhall E, Shepard JL, Zon LI. Hematopoietic stem cell fate is established by the Notch-Runx pathway. Genes Dev. 2005;19(19):2331-42.

33. Nakagawa M, Ichikawa M, Kumano K, Goyama S, Kawazu M, Asai T, et al. AML1/Runx1 rescues Notch1-null mutation-induced deficiency of para-aortic splanchnopleural hematopoiesis. Blood. 2006;108(10):3329-34.

34. Duncan AW, Rattis FM, DiMascio LN, Congdon KL, Pazianos G, Zhao C, et al. Integration of Notch and Wnt signaling in hematopoietic stem cell maintenance. Nat Immunol. 2005;6(3):314-22.

35. Wilson A, Laurenti E, Oser G, van der Wath RC, Blanco-Bose W, Jaworski M, et al. Hematopoietic stem cells reversibly switch from dormancy to self-renewal during homeostasis and repair. Cell. 2008;135(6):1118-29.

36. Morrison SJ, Kimble J. Asymmetric and symmetric stem-cell divisions in development and cancer. Nature. 2006;441(7097):1068-74.

37. Stoffel R, Ziegler S, Ghilardi N, Ledermann B, de Sauvage FJ, Skoda RC. Permissive role of thrombopoietin and granulocyte colony-stimulating factor receptors in hematopoietic cell fate decisions in vivo. Proc Natl Acad Sci U S A. 1999;96(2):698-702.

38. Rieger MA, Hoppe PS, Smejkal BM, Eitelhuber AC, Schroeder T. Hematopoietic cytokines can instruct lineage choice. Science. 2009;325(5937):217-8.

39. Scott EW, Simon MC, Anastasi J, Singh H. Requirement of transcription factor PU.1 in the development of multiple hematopoietic lineages. Science. 1994;265(5178):1573-7.

40. Walsh JC, DeKoter RP, Lee HJ, Smith ED, Lancki DW, Gurish MF, et al. Cooperative and antagonistic interplay between PU.1 and GATA-2 in the specification of myeloid cell fates. Immunity. 2002;17(5):665-76.

41. Rothenberg EV, Champhekar A, Damle S, Del Real MM, Kueh HY, Li L, et al. Transcriptional establishment of cell-type identity: dynamics and causal mechanisms of T-cell lineage commitment. Cold Spring Harb Symp Quant Biol. 2013;78(1):31-41.

42. Monticelli S, Natoli G. Transcriptional determination and functional specificity of myeloid cells: making sense of diversity. Nat Rev Immunol. 2017;17(10):595-607.

43. Dahl $R$, Walsh JC, Lancki $D$, Laslo $P$, lyer SR, Singh $H$, et al. Regulation of macrophage and neutrophil cell fates by the PU.1:C/EBPalpha ratio and granulocyte colony-stimulating factor. Nat Immunol. 2003;4(10):1029-36.

44. Reddy VA, Iwama A, lotzova G, Schulz M, Elsasser A, Vangala RK, et al. Granulocyte inducer C/EBPalpha inactivates the myeloid master regulator PU.1: possible role in lineage commitment decisions. Blood. 2002;100(2):483-90.

45. Carotta S, Dakic A, D'Amico A, Pang SH, Greig KT, Nutt SL, et al. The transcription factor PU.1 controls dendritic cell development and Flt3 cytokine receptor expression in a dosedependent manner. Immunity. 2010;32(5):628-41. 
46. Martin DI, Orkin SH. Transcriptional activation and DNA binding by the erythroid factor GF1/NF-E1/Eryf 1. Genes Dev. 1990;4(11):1886-98.

47. Weiss MJ, Keller G, Orkin SH. Novel insights into erythroid development revealed through in vitro differentiation of GATA-1 embryonic stem cells. Genes Dev. 1994;8(10):1184-97.

48. Iwasaki H, Mizuno S, Arinobu Y, Ozawa H, Mori Y, Shigematsu H, et al. The order of expression of transcription factors directs hierarchical specification of hematopoietic lineages. Genes Dev. 2006;20(21):3010-21.

49. Tsai FY, Orkin SH. Transcription factor GATA-2 is required for proliferation/survival of early hematopoietic cells and mast cell formation, but not for erythroid and myeloid terminal differentiation. Blood. 1997;89(10):3636-43.

50. Fujiwara Y, Chang AN, Williams AM, Orkin SH. Functional overlap of GATA-1 and GATA-2 in primitive hematopoietic development. Blood. 2004;103(2):583-5.

51. Ho IC, Vorhees P, Marin N, Oakley BK, Tsai SF, Orkin SH, et al. Human GATA-3: a lineagerestricted transcription factor that regulates the expression of the $T$ cell receptor alpha gene.

EMBO J. 1991;10(5):1187-92.

52. Frelin C, Herrington R, Janmohamed S, Barbara M, Tran G, Paige CJ, et al. GATA-3 regulates the self-renewal of long-term hematopoietic stem cells. Nat Immunol.

2013;14(10):1037-44.

53. Ho IC, Tai TS, Pai SY. GATA3 and the T-cell lineage: essential functions before and after Thelper-2-cell differentiation. Nat Rev Immunol. 2009;9(2):125-35.

54. Hosoya T, Maillard I, Engel JD. From the cradle to the grave: activities of GATA-3 throughout T-cell development and differentiation. Immunol Rev. 2010;238(1):110-25.

55. Wang Y, Misumi I, Gu AD, Curtis TA, Su L, Whitmire JK, et al. GATA-3 controls the maintenance and proliferation of T cells downstream of TCR and cytokine signaling. Nat Immunol. 2013;14(7):714-22.

56. Lentjes MH, Niessen HE, Akiyama $Y$, de Bruine AP, Melotte $\mathrm{V}$, van Engeland $M$. The emerging role of GATA transcription factors in development and disease. Expert Rev Mol Med. 2016;18:e3.

57. Friedenstein AJ, Latzinik NW, Grosheva AG, Gorskaya UF. Marrow microenvironment transfer by heterotopic transplantation of freshly isolated and cultured cells in porous sponges. Exp Hematol. 1982;10(2):217-27.

58. Caplan Al. Mesenchymal stem cells. J Orthop Res. 1991;9(5):641-50.

59. Dominici M, Le Blanc K, Mueller I, Slaper-Cortenbach I, Marini F, Krause D, et al. Minimal criteria for defining multipotent mesenchymal stromal cells. The International Society for Cellular Therapy position statement. Cytotherapy. 2006;8(4):315-7.

60. Guerreiro R, Santos-Costa Q, Azevedo-Pereira JM. [The chemokines and their receptors: characteristics and physiological functions]. Acta Med Port. 2011;24(Supl 4):967-76.

Portuguese.

61. Nagasawa T, Hirota S, Tachibana K, Takakura N, Nishikawa S, Kitamura Y, et al. Defects of B-cell lymphopoiesis and bone-marrow myelopoiesis in mice lacking the CXC chemokine PBSF/SDF-1. Nature. 1996;382(6592):635-8. 
62. Ara T, Itoi M, Kawabata K, Egawa T, Tokoyoda K, Sugiyama T, et al. A role of CXC chemokine ligand 12/stromal cell-derived factor-1/pre-B cell growth stimulating factor and its receptor CXCR4 in fetal and adult T cell development in vivo. J Immunol. 2003;170(9):4649-55.

63. Tokoyoda K, Egawa T, Sugiyama T, Choi BI, Nagasawa T. Cellular niches controlling B lymphocyte behavior within bone marrow during development. Immunity. 2004;20(6):707-18.

64. Kohara H, Omatsu Y, Sugiyama T, Noda M, Fujii N, Nagasawa T. Development of plasmacytoid dendritic cells in bone marrow stromal cell niches requires CXCL12-CXCR4 chemokine signaling. Blood. 2007;110(13):4153-60.

65. Noda M, Omatsu Y, Sugiyama T, Oishi S, Fujii N, Nagasawa T. CXCL12-CXCR4 chemokine signaling is essential for NK-cell development in adult mice. Blood. $2011 ; 117(2): 451-8$.

66. Omatsu Y, Sugiyama T, Kohara H, Kondoh G, Fujii N, Kohno K, et al. The essential functions of adipo-osteogenic progenitors as the hematopoietic stem and progenitor cell niche. Immunity. 2010;33(3):387-99.

67. Sacchetti B, Funari A, Michienzi S, Di Cesare S, Piersanti S, Saggio I, et al. Self-renewing osteoprogenitors in bone marrow sinusoids can organize a hematopoietic microenvironment. Cell. 2007;131(2):324-36.

68. Pinho S, Lacombe J, Hanoun M, Mizoguchi T, Bruns I, Kunisaki Y, et al. PDGFRa and CD51 mark human nestin ${ }^{+}$sphere-forming mesenchymal stem cells capable of hematopoietic progenitor cell expansion. J Exp Med. 2013;210(7):1351-67.

69. Ding L, Morrison SJ. Haematopoietic stem cells and early lymphoid progenitors occupy distinct bone marrow niches. Nature. 2013;495(7440):231-5.

70. Greenbaum A, Hsu YM, Day RB, Schuettpelz LG, Christopher MJ, Borgerding JN, et al. CXCL12 in early mesenchymal progenitors is required for haematopoietic stem-cell maintenance. Nature. 2013;495(7440):227-30.

71. Lendahl U, Zimmerman LB, McKay RD. CNS stem cells express a new class of intermediate filament protein. Cell. 1990;60(4):585-95.

72. Katayama Y, Battista M, Kao WM, Hidalgo A, Peired AJ, Thomas SA, et al. Signals from the sympathetic nervous system regulate hematopoietic stem cell egress from bone marrow. Cell. 2006;124(2):407-21.

73. Mendez-Ferrer S, Lucas D, Battista M, Frenette PS. Haematopoietic stem cell release is regulated by circadian oscillations. Nature. 2008;452(7186):442-7.

74. Ding L, Saunders TL, Enikolopov G, Morrison SJ. Endothelial and perivascular cells maintain haematopoietic stem cells. Nature. 2012;481(7382):457-62.

75. Kunisaki Y, Bruns I, Scheiermann C, Ahmed J, Pinho S, Zhang D, et al. Arteriolar niches maintain haematopoietic stem cell quiescence. Nature. 2013;502(7473):637-43.

76. Acar M, Kocherlakota KS, Murphy MM, Peyer JG, Oguro H, Inra CN, et al. Deep imaging of bone marrow shows non-dividing stem cells are mainly perisinusoidal. Nature.

2015;526(7571):126-30. 
77. Asada N, Kunisaki Y, Pierce H, Wang Z, Fernandez NF, Birbrair A, et al. Differential cytokine contributions of perivascular haematopoietic stem cell niches. Nat Cell Biol. 2017;19(3):214-23.

78. Shirozu M, Nakano T, Inazawa J, Tashiro K, Tada H, Shinohara T, et al. Structure and chromosomal localization of the human stromal cell-derived factor 1 (SDF1) gene. Genomics. $1995 ; 28(3): 495-500$.

79. Yu L, Cecil J, Peng SB, Schrementi J, Kovacevic S, Paul D, et al. Identification and expression of novel isoforms of human stromal cell-derived factor 1. Gene. 2006;374(1-2):1749.

80. Pawig L, Klasen C, Weber C, Bernhagen J, Noels H. Diversity and inter-connections in the CXCR4 chemokine receptor/ligand family: molecular perspectives. Front Immunol. 2015;6(8):429.

81. Crump MP, Gong JH, Loetscher P, Rajarathnam K, Amara A, Arenzana-Seisdedos F, et al. Solution structure and basis for functional activity of stromal cell-derived factor-1; dissociation of CXCR4 activation from binding and inhibition of HIV-1. EMBO J. 1997;16(23):6996-7007.

82. Ma Q, Jones D, Springer TA. The chemokine receptor CXCR4 is required for the retention of $B$ lineage and granulocytic precursors within the bone marrow microenvironment. Immunity. $1999 ; 10(4): 463-71$.

83. Zou YR, Kottmann AH, Kuroda M, Taniuchi I, Littman DR. Function of the chemokine receptor CXCR4 in haematopoiesis and in cerebellar development. Nature. 1998;393(6685):595-9.

84. Balabanian K, Lagane B, Infantino S, Chow KY, Harriague J, Moepps B, et al. The chemokine SDF-1/CXCL12 binds to and signals through the orphan receptor RDC1 in T lymphocytes. J Biol Chem. 2005;280(42):35760-6.

85. Marchese A, Raiborg C, Santini F, Keen JH, Stenmark H, Benovic JL. The E3 ubiquitin ligase AIP4 mediates ubiquitination and sorting of the G protein-coupled receptor CXCR4. Dev Cell. 2003;5(5):709-22.

86. Mellado M, Rodriguez-Frade JM, Manes S, Martinez-A C. Chemokine signaling and functional responses: the role of receptor dimerization and TK pathway activation. Annu Rev Immunol. 2001;19:397-421.

87. Wurth R, Bajetto A, Harrison JK, Barbieri F, Florio T. CXCL12 modulation of CXCR4 and CXCR7 activity in human glioblastoma stem-like cells and regulation of the tumor microenvironment. Front Cell Neurosci. 2014;8:144.

88. Busillo JM, Benovic JL. Regulation of CXCR4 signaling. Biochim Biophys Acta. 2007;1768(4):952-63.

89. Singh AK, Arya RK, Trivedi AK, Sanyal S, Baral R, Dormond O, et al. Chemokine receptor trio: CXCR3, CXCR4 and CXCR7 crosstalk via CXCL11 and CXCL12. Cytokine Growth Factor Rev. 2013;24(1):41-9.

90. Nie Y, Han YC, Zou YR. CXCR4 is required for the quiescence of primitive hematopoietic cells. J Exp Med. 2008;205(4):777-83. 
91. Tzeng YS, Li H, Kang YL, Chen WC, Cheng WC, Lai DM. Loss of Cxcl12/Sdf-1 in adult mice decreases the quiescent state of hematopoietic stem/progenitor cells and alters the pattern of hematopoietic regeneration after myelosuppression. Blood. 2011;117(2):429-39.

92. Reya T, Duncan AW, Ailles L, Domen J, Scherer DC, Willert K, et al. A role for Wnt signalling in self-renewal of haematopoietic stem cells. Nature. 2003;423:409-14.

93. Willert K, Brown JD, Danenberg E, Duncan AW, Weissman IL, Reya T, et al. Wnt proteins are lipid-modified and can act as stem cell growth factors. Nature. 2003;423:448-52.

94. Staal FJ, Luis TC, Tiemessen MM. WNT signalling in the immune system: WNT is spreading its wings. Nat Rev Immunol. 2008;8(8):581-93.

95. Chien AJ, Conrad WH, Moon RT. A Wnt survival guide: from flies to human disease. J Invest Dermatol. 2009;129(7):1614-27.

96. Staal FJ, Clevers HC. WNT signalling and haematopoiesis: a WNT-WNT situation. Nat Rev Immunol. 2005;5(1):21-30.

97. Scheller M, Huelsken J, Rosenbauer F, Taketo MM, Birchmeier W, Tenen DG, et al. Hematopoietic stem cell and multilineage defects generated by constitutive $\beta$-catenin activation. Nat Immunol. 2006;7(10):1037-47.

98. Kirstetter P, Anderson K, Porse BT, Jacobsen SE, Nerlov C. Activation of the canonical Wnt pathway leads to loss of hematopoietic stem cell repopulation and multilineage differentiation block. Nat Immunol. 2006;7(10):1048-56.

99. Luis TC, Weerkamp F, Naber BA, Baert MR, de Haas EF, Nikolic T, et al. Wnt3a deficiency irreversibly impairs hematopoietic stem cell self-renewal and leads to defects in progenitor cell differentiation. Blood. 2009;113(3):546-54.

100. Koch U, Wilson A, Cobas M, Kemler R, Macdonald HR, Radtke F, et al. Simultaneous loss of beta- and gamma-catenin does not perturb hematopoiesis or lymphopoiesis. Blood.

2008;111(1):160-4.

101. Jeannet G, Scheller M, Scarpellino L, Duboux S, Gardiol N, Back J, et al. Long-term, multilineage hematopoiesis occurs in the combined absence of $\beta$-catenin and gamma-catenin. Blood. 2008;111(1):142-9.

102. Nemeth MJ, Topol L, Anderson SM, Yang Y, Bodine DM. Wnt5a inhibits canonical Wnt signaling in hematopoietic stem cells and enhances repopulation. Proc Natl Acad Sci U S A. 2007;104(39):15436-41.

103. Sugimura R, He XC, Venkatraman A, Arai F, Box A, Semerad C, et al. Noncanonical Wnt signaling maintains hematopoietic stem cells in the niche. Cell. 2012;150(2):351-65.

104. Sudo K, Ema H, Morita Y, Nakauchi H. Age-associated characteristics of murine hematopoietic stem cells. J Exp Med. 2000;192(9):1273-80.

105. Geiger H, Koehler A, Gunzer M. Stem cells, aging, niche, adhesion and Cdc42: a model for changes in cell-cell interactions and hematopoietic stem cell aging. Cell Cycle. 2007;6(8):884-7.

106. Dykstra B, Olthof S, Schreuder J, Ritsema M, de Haan G. Clonal analysis reveals multiple functional defects of aged murine hematopoietic stem cells. J Exp Med. 2011;208(13):2691703. 
107. Geiger H, de Haan G, Florian MC. The ageing haematopoietic stem cell compartment. Nat Rev Immunol. 2013;13(5):376-89.

108. Beerman I, Bhattacharya D, Zandi S, Sigvardsson M, Weissman IL, Bryder D, et al. Functionally distinct hematopoietic stem cells modulate hematopoietic lineage potential during aging by a mechanism of clonal expansion. Proc Natl Acad Sci U S A. 2010;107(12):5465-70.

109. Rossi DJ, Bryder D, Zahn JM, Ahlenius H, Sonu R, Wagers AJ, et al. Cell intrinsic alterations underlie hematopoietic stem cell aging. Proc Natl Acad Sci U S A.

2005;102(26):9194-9.

110. Miller JP, Allman D. Linking age-related defects in B lymphopoiesis to the aging of hematopoietic stem cells. Semin Immunol. 2005;17(5):321-9.

111. Ergen AV, Boles NC, Goodell MA. Rantes / Ccl5 influences hematopoietic stem cell subtypes and causes myeloid skewing. Blood. 2012;119(11):2500-9.

112. O'Hagan-Wong K, Nadeau S, Carrier-Leclerc A, Apablaza F, Hamdy R, Shum-Tim D, et al. Increased IL-6 secretion by aged human mesenchymal stromal cells disrupts hematopoietic stem and progenitor cells' homeostasis. Oncotarget. 2016;7(12):13285-96.

113. Gnani D, Crippa S, Della Volpe L, Rossella V, Conti A, Lettera E, et al. An earlysenescence state in aged mesenchymal stromal cells contributes to hematopoietic stem and progenitor cell clonogenic impairment through the activation of a pro-inflammatory program. Aging Cell. 2019;18(3):e12933.

114. Koler A, Schmithorst V, Filippi MD, Ryan MA, Daria D, Gunzer M, et al. Altered cellular dynamics and endosteal location of aged early hematopoietic progenitor cells revealed by timelapse intravital imaging in long bones. Blood. 2009;114(2):290-8.

115. Naveiras O, Nardi V, Wenzel PL, Hauschka PV, Fahey F, Daley GQ. Bone-marrow adipocytes as negative regulators of the haematopoietic microenvironment. Nature. 2009;460(7252):259-63.

116. Siclari VA, Zhu J, Akiyama K, Liu F, Zhang X, Chandra A, et al. Mesenchymal progenitors residing close to the bone surface are functionally distinct from those in the central bone marrow. Bone. 2013;53(2):575-86.

117. Maryanovich M, Zahalka AH, Pierce H, Pinho S, Nakahara F, Asada N, et al. Adrenergic nerve degeneration in bone marrow drives aging of the hematopoietic stem cell niche. Nat Med. 2018;24(6):782-91.

118. Benedito SS. Influência do envelhecimento das células-tronco mesenquimais na autorrenovação, diferenciação e multipotência de células-tronco hematopoéticas [dissertação]. [São Paulo]. Universidade de São Paulo; 2010.

119. Lee GY, Jeong SY, Lee HR, Oh IH. Age-related differences in the bone marrow stem cell niche generate specialized microenvironments for the distinct regulation of normal hematopoietic and leukemia stem cells. Sci Rep. 2019;9(1):1007.

120. Sutherland DR, Anderson L, Keeney M, Nayar R, Chin-Yee I; International Society of Hematotherapy and Graft Engineering. The ISHAGE guidelines for CD34+ cell determination by flow cytometry. J Hematother. 1996;5(3):213-26.

121. Sutherland DR, Keeney M, Gratama JW. Enumeration of CD34+ hematopoietic stem and progenitor cells. Curr Protoc Cytom. 2003;25(1):6.4.1-6.4.23. 
122. Azouna NB, Berraeis L, Regaya Z, Jenhani F. Immunophenotyping of hematopoietic progenitor cells: comparison between cord blood and adult mobilized blood grafts. World J Stem Cells. 2011;3(11):104-12.

123. Whitby A, Whitby L, Fletcher M, Reilly JT, Sutherland DR, Keeney M, et al. ISHAGE protocol: are we doing it correctly? Cytometry B Clin Cytom. 2012;82B (1):9-17.

124. Livak KJ, Schmittgen TD. Analysis of relative gene expression data using real-time quantitative PCR and the 2(- $\Delta \Delta \mathrm{C}(\mathrm{T}))$ Method. Methods. 2001;25(4):402-8.

125. Nascimento S, Suarez ER, Pinhal MA. Tecnologia de PCR e RT-PCR em tempo real e suas aplicações na área médica. Rev Bras Med. 2010;67:7-19.

126. Nadri S, Soleimani M, Hosseni RH, Massumi M, Atashi A, Izadpanah R. An efficient method for isolation of murine bone marrow mesenchymal stem cells. Int $\mathrm{J}$ Dev Biol. 2007;51(8):723-9.

127. Whitby A, Whitby L, Fletcher M, Reilly JT, Sutherland DR, Keeney M, et al. ISHAGE protocol: are we doing it correctly? Cytometry B Clin Cytom. 2012;82(1):9-17.

128. DeKoter RP, Singh H. Regulation of B lymphocyte and macrophage development by graded expression of PU.1. Science. 2000;288(5470):1439-42.

129. Arinobu $Y$, Mizuno S, Chong $Y$, Shigematsu $H$, lino $T$, Iwasaki $H$, et al. Reciprocal activation of GATA-1 and PU.1 marks initial specification of hematopoietic stem cells into myeloerythroid and myelolymphoid lineages. Cell Stem Cell. 2007;1(4):416-27.

130. Ting CN, Olson MC, Barton KP, Leiden JM. Transcription factor GATA-3 is required for development of the T-cell lineage. Nature. 1996;384(6608):474-8.

131. Georgopoulos K, Winandy S, Avitahl N. The role of the lkaros gene in lymphocyte development and homeostasis. Annu Rev Immunol. 1997;15:155-76.

132. Zhang DH, Cohn L, Ray P, Bottomly K, Ray A. Transcription factor GATA-3 is differentially expressed in murine Th1 and Th2 cells and controls Th2-specific expression of the interleukin-5 gene. J Biol Chem. 1997;272(34):21597-603.

133. Zheng W, Flavell RA. The transcription factor GATA-3 is necessary and sufficient for Th2 cytokine gene expression in CD4 T cells. Cell. 1997;89(4):587-96.

134. Matthias $P$, Rolink AG. Transcriptional networks in developing and mature $B$ cells. Nat Rev Immunol. 2005;5(6):497-508.

135. Fleming HE, Janzen V, Lo Celso C, Guo J, Leahy KM, Kronenberg HM, et al. Wnt signaling in the niche enforces hematopoietic stem cell quiescence and is necessary to preserve self-renewal in vivo. Cell Stem Cell. 2008;2(3):274-83.

136. Povinelli BJ, Nemeth MJ. Wnt5a regulates hematopoietic stem cell proliferation and repopulation through the Ryk receptor. Stem Cells. 2014;32(1)105-15.

137. Haleem-Smith H, Derfoul A, Okafor C, Tuli R, Olsen D, Hall DJ, et al. Optimization of highefficiency transfection of adult human mesenchymal stem cells in vitro. Mol Biotechnol. 2005;30(1):9-20.

138. Naldini L, Blomer U, Gallay P, Ory D, Mulligan R, Gage FH, et al. In vivo gene delivery and stable transduction of nondividing cells by a lentiviral vector. Science. 1996;272(5259):263-7. 
139. Oggu GS, Sasikumar S, Reddy N, Ella KK, Rao CM, Bokara KK. Gene delivery approaches for mesenchymal stem cell therapy: strategies to increase efficiency and specificity. Stem Cell Rev Rep. 2017;13(6):725-40.

140. Wang F, Dennis JE, Awadallah A, Solchaga LA, Molter J, Kuang Y, et al. Transcriptional profiling of human mesenchymal stem cells transduced with reporter genes for imaging. Physiol Genomics. 2009;37(1):23-34.

141. Kallifatidis G, Beckermann BM, Groth A, Schubert M, Apel A, Khamidjanov A, et al. Improved lentiviral transduction of human mesenchymal stem cells for therapeutic intervention in pancreatic cancer. Cancer Gene Ther. 2008;15(4):231-40.

142. Lin P, Correa D, Lin Y, Caplan Al. Polybrene inhibits human mesenchymal stem cell proliferation during lentiviral transduction. PLoS One. 2011;6(8):e23891.

143. Deryabin P, Griukova A, Shatrova A, Petukhov A, Nikolsky N, Borodkina A. Optimization of lentiviral transduction parameters and its application for CRISPR-based secretome modification of human endometrial mesenchymal stem cells. Cell Cycle. 2019;18(6-7):742-58.

144. Zandstra PW, Conneally E, Petzer AL, Piret JM, Eaves CJ. Cytokine manipulation of primitive human hematopoietic cell self-renewal. Proc Natl Acad Sci U S A. 1997;94(9):4698703.

145. Ema H, Takano $H$, Sudo $K$, Nakauchi $H$. In vitro self-renewal division of hematopoietic stem cells. J Exp Med. 2000;192(9):1281-8.

146. Li L, Clevers H. Coexistence of quiescent and active adult stem cells in mammals. Science. 2010; 327(5965):542-5.

147. Lim VY, Zehentmeier S, Fistonich C, Pereira JP. A chemoattractant-guided walk through lymphopoiesis: from hematopoietic stem cells to mature B lymphocytes. Adv Immunol. 2017;134(134):47-88.

148. Tamplin OJ, Durand EM, Carr LA, Childs SJ, Hagedorn EJ, Li P, et al. Hematopoietic stem cell arrival triggers dynamic remodeling of the perivascular niche. Cell. 2015;160(1-2):241-52.

149. Doulatov S, Notta F, Eppert K, Nguyen LT, Ohashi PS, Dick JE. Revised map of the human progenitor hierarchy shows the origin of macrophages and dendritic cells in early lymphoid development. Nat Immunol. 2010;11(7):585-93.

150. Hennrich ML, Romanov N, Horn P, Jaeger S, Eckstein V, Steeples V, et al. Cell-specific proteome analyses of human bone marrow reveal molecular features of age-dependent functional decline. Nat Commun. 2018;9(1):4004.

151. Jing D, Fonseca AV, Alakel N, Fierro FA, Muller K, Bornhauser M, et al. Hematopoietic stem cells in co-culture with mesenchymal stromal cells-modeling the niche compartments in vitro. Haematologica. 2010;95(4):542-50.

152. Alakel N, Jing D, Muller K, Bornhauser M, Ehninger G, Ordemann R. Direct contact with mesenchymal stromal cells affects migratory behavior and gene expression profile of CD133+ hematopoietic stem cells during ex vivo expansion. Exp Hematol. 2009;37(4):504-13.

153. Kurotaki D, Osato N, Nishiyama A, Yamamoto M, Ban T, Sato $H$, et al. Essential role of the IRF8-KLF4 transcription factor cascade in murine monocyte differentiation. Blood.

2013;121(10):1839-49. 
154. Luis TC, Naber BA, Roozen PP, Brugman MH, de Haas EF, Ghazvini M, et al. Canonical wnt signaling regulates hematopoiesis in a dosage-dependent fashion. Cell Stem Cell. 2011;9(4):345-56.

155. Zhou S. Paracrine effects of haematopoietic cells on human mesenchymal stem cells. Sci Rep. 2015;5:10573.

156. Cook MM, Futrega K, Osiecki M, Kabiri M, Kul B, Rice A, et al. Micromarrows-threedimensional coculture of hematopoietic stem cells and mesenchymal stromal cells. Tissue Eng Part C Methods. 2012;18(5):319-28.

157. Schmal O, Seifert J, Schaffer TE, Walter CB, Aicher WK, Klein G. Hematopoietic stem and progenitor cell expansion in contact with mesenchymal stromal cells in a hanging drop model uncovers disadvantages of 3D culture. Stem Cells Int. 2016;2016:4148093.

158. Futrega K, Atkinson K, Lott WB, Doran MR. Spheroid coculture of hematopoietic stem/progenitor cells and monolayer expanded mesenchymal stem/stromal cells in polydimethylsiloxane microwells modestly improves in vitro hematopoietic stem/progenitor cell expansion. Tissue Eng Part C Methods. 2017;23(4):200-18.

159. Jeon S, Lee HS, Lee GY, Park G, Kim TM, Shin J, et al. Shift of EMT gradient in 3D spheroid MSCs for activation of mesenchymal niche function. Sci Rep. 2017;7(1):6859.

160. Hao QL, Shah AJ, Thiemann FT, Smogorzewska EM, Crooks GM. A functional comparison of CD34 + CD38- cells in cord blood and bone marrow. 1995;86(10):3745-53.

161. Bender JG, Unverzagt K, Walker DE, Lee W, Smith S, Williams S, et al. Phenotypic analysis and characterization of CD34+ cells from normal human bone marrow, cord blood, peripheral blood, and mobilized peripheral blood from patients undergoing autologous stem cell transplantation. Clin Immunol Immunopathol. 1994;70(1):10-8.

162. Belvedere O, Feruglio C, Malangone W, Bonora ML, Donini A, Dorotea L, et al. Phenotypic characterization of immunomagnetically purified umbilical cord blood CD34+ cells. Blood Cells Mol Dis. 1999;25(3-4):141-6.

163. Dorrell C, Gan OI, Pereira DS, Hawley RG, Dick JE. Expansion of human cord blood CD34(+)CD38(-) cells in ex vivo culture during retroviral transduction without a corresponding increase in SCID repopulating cell (SRC) frequency: dissociation of SRC phenotype and function. Blood. 2000;95(1):102-10.

164. McKenzie JL, Gan OI, Doedens M, Dick JE. Reversible cell surface expression of CD38 on CD34-positive human hematopoietic repopulating cells. Exp Hematol. 2007;35(9):1429-36.

165. Goode DK, Obier N, Vijayabaskar MS, Lie-A-Ling M, Lilly AJ, Hannah R, et al. Dynamic gene regulatory networks drive hematopoietic specification and differentiation. Dev Cell. 2016;36(5):572-87.

166. Garber M, Yosef N, Goren A, Raychowdhury R, Thielke A, Guttman M, et al. A highthroughput chromatin immunoprecipitation approach reveals principles of dynamic gene regulation in mammals. Mol Cell. 2012;47(5):810-22.

167. Natoli G, Ghisletti S, Barozzi I. The genomic landscapes of inflammation. Genes Dev. $2011 ; 25(2): 101-6$. 
168. Barozzi I, Simonatto M, Bonifacio S, Yang L, Rohs R, Ghisletti S, et al. Coregulation of transcription factor binding and nucleosome occupancy through DNA features of mammalian enhancers. Mol Cell. 2014;54(5):844-57.

169. Heinz S, Benner C, Spann N, Bertolino E, Lin YC, Laslo P, et al. Simple combinations of lineage-determining transcription factors prime cis-regulatory elements required for macrophage and B cell identities. Mol Cell. 2010;38(4):576-89.

170. Kim J, Kang YJ, Park G, Kim M, Park YO Identification of a stroma-mediated Wnt/ $\beta$-catenin signal promoting self-renewal of hematopoietic stem cells in the stem cell niche. Stem Cells. 2009;27(6):1318-29.

171. Hamm A, Krott N, Breibach I, Blindt R, Bosserhoff AK. Efficient transfection method for primary cells. Tissue Eng. 2002;8(2):235-45.

172. Ferreira E, Potier E, Logeart-Avramoglou D, Salomskaite-Davalgiene S, Mir LM, Petite H. Optimization of a gene electrotransfer method for mesenchymal stem cell transfection. Gene Ther. 2008;15(7):537-44.

173. Grinev VV, Severin IN, Posrednik DV, Kosmacheva SM, Potapnev MP. [Highly efficient transfer and stable expression of two genes upon lentivirus transduction of mesenchymal stem cells from human bone marrow]. Genetika. 2012;48(3):389-400. Russian.

174. Gonzalez Villarreal C, Said Fernandez S, Soto Dominguez A, Padilla Rivas G, Garza Trevino E, Rodriguez Rocha $\mathrm{H}$, et al. Bone marrow mesenchymal stem cells: improving transgene expression level, transfection efficiency and cell viability. J BUON. 2018;23(6):1893903.

175. de Carvalho TG, Pellenz FM, Laureano A, da Rocha Silla LM, Giugliani R, Baldo G, et al. A simple protocol for transfecting human mesenchymal stem cells. Biotechnol Lett. 2018;40(3):617-22.

176. Rossi L, Manfredini R, Bertolini F, Ferrari D, Fogli M, Zini R, et al. The extracellular nucleotide UTP is a potent inducer of hematopoietic stem cell migration. Blood.

2007;109(2):533-42.

177. Mohrin M, Bourke E, Alexander D, Warr MR, Barry-Holson K, Le Beau MM, et al. Hematopoietic stem cell quiescence promotes error-prone DNA repair and mutagenesis. Cell Stem Cell. 2010;7(2):174-85.

178. Yahata T, Takanashi T, Muguruma $Y$, Ibrahim AA, Matsuzawa $H$, Uno $T$, et al. Accumulation of oxidative DNA damage restricts the self-renewal capacity of human hematopoietic stem cells. Blood. 2011;118(11):2941-50.

179. Bennett-Baker PE, Wilkowski J, Burke DT. Age-associated activation of epigenetically repressed genes in the mouse. Genetics. 2003;165(4):2055-62.

180. Chambers SM, Shaw CA, Gatza C, Fisk CJ, Donehower LA, Goodell MA. Aging hematopoietic stem cells decline in function and exhibit epigenetic dysregulation. PLoS Biol. 2007;5(8):e201.

181. Muller-Sieburg CE, Cho RH, Thoman M, Adkins B, Sieburg HB. Deterministic regulation of hematopoietic stem cell self-renewal and differentiation. Blood. 2002;100(4):1302-9. 
182. Cho RH, Sieburg HB, Muller-Sieburg CE. A new mechanism for the aging of hematopoietic stem cells: aging changes the clonal composition of the stem cell compartment but not individual stem cells. Blood. 2008;111(12):5553-61.

183. Muller-Sieburg C, Sieburg HB. Stem cell aging: survival of the laziest? Cell Cycle. 2008;7(24):3798-804.

184. Challen GA, Boles NC, Chambers SM, Goodell MA. Distinct hematopoietic stem cell subtypes are differentially regulated by TGF- $\beta 1$. Cell Stem Cell. 2010;6(3):265-78. 


\begin{abstract}
Introduction: Hematopoietic stem cells are the only cells that are capable to producing all blood cell lines throughout a lifetime. In the bone marrow, there is a strictly controlled local microenvironment or niche that regulates the quiescence, proliferation, and differentiation of hematopoietic stem cells. Previous studies have shown that mesenchymal stem cells can regulate the hematopoietic stem cell niche. Although the mechanisms are not fully understood, these cells express genes associated with the maintenance of hematopoietic stem cells and their retention in the niche, including those encoding the chemokine CXCL12 and the stem cell factor. Purpose: This study aimed to determine the role of CXCL12 in multipotency, self-renewal, and differentiation of human hematopoietic stem cells, and also correlate the effects of aging of mesenchymal stem cells in a mouse transplantation model. Methods: Treatment of CXCL12 in the cultivation of hematopoietic stem cells was used and after 3 and 7 days immunophenotypic and gene expression analyses related to differentiation, self-renewal, and $\beta$-catenin were performed. For the analysis of silencing of CXCL12 in stromal cells the silencing method using the siRNA and the shRNA was used. For the study in animal models, we used the spinal flush technique and compared the immunophenotypic profile of hematopoietic stem cells in young and older mice, and isolated stromal cells from animals. We also investigated the influence of co-cultivation of hematopoietic stem cells with mesenchymal stem cells on gene expression of differentiation, multipotency, and the $\beta$-catenin protein. Results: Our results showed that hematopoietic stem cells cultured in the presence of CXCL12 led to an upregulation of genes associated with multipotency, a downregulation of genes involved in lineage differentiation, and to an increased protein expression of $\beta$ catenin. We have also initiated experiments in animal models and analyzed bone marrow from young and old mice. Younger mice expressed significantly higher percentages of Lin-cKit+Sca1+ cells compared to the older mice. Conclusion: Treatment with CXCL12 may contribute to multipotency and pool maintenance as well as to their undifferentiated phenotype with hematopoietic stem cells. In accordance with the human findings, the older mice showed a reduced pool of hematopoietic stem cells in the bone marrow.
\end{abstract}

Keywords: Hematopoietic stem cells; Chemokine CXCL12; Mesenchymal stem cells 


\section{Apêndices}

Apêndice 1. O cocultivo de células-tronco hematopoéticas com células-tronco mesenquimais leva ao aumento da expressão de genes relacionados à diferenciação de linhagem hematopoética

A

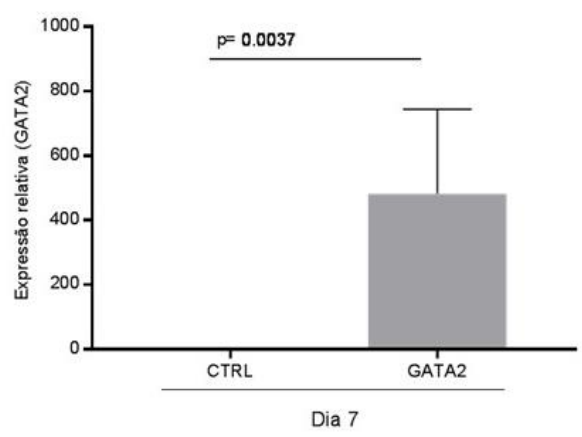

B

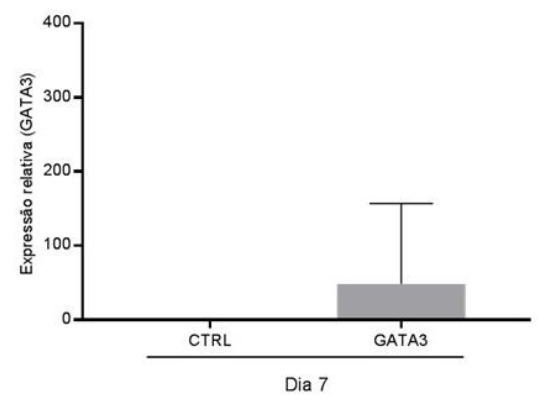

C

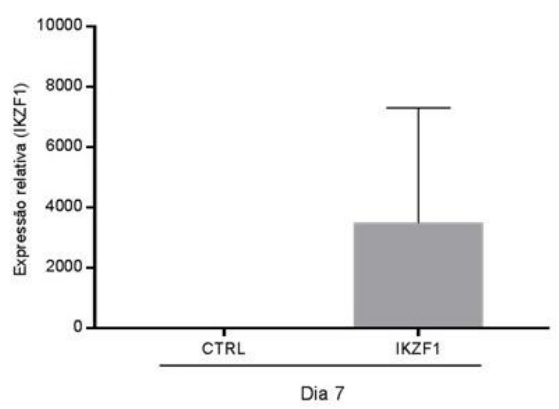

GATA2

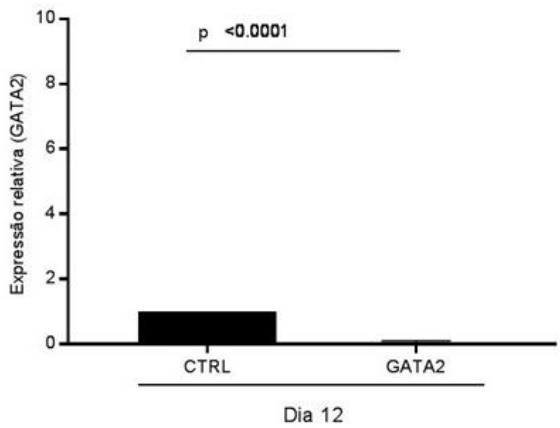

GATA3

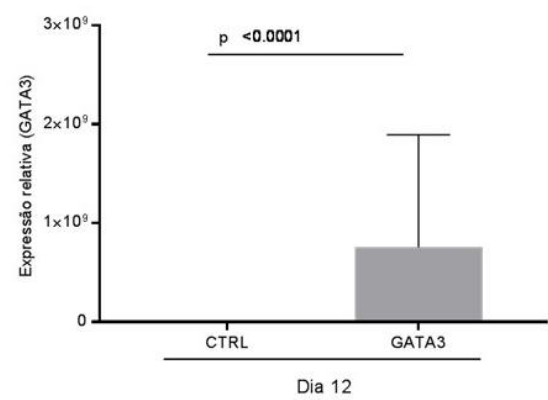

IKZF1

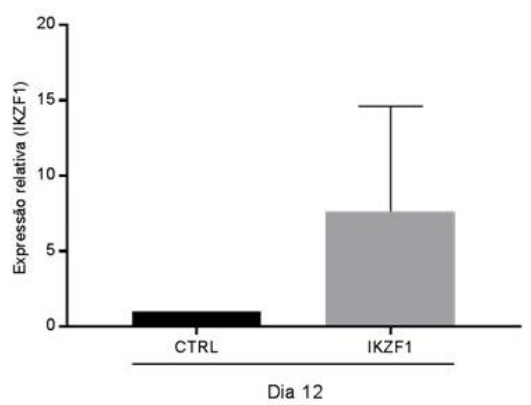

continua... 
D

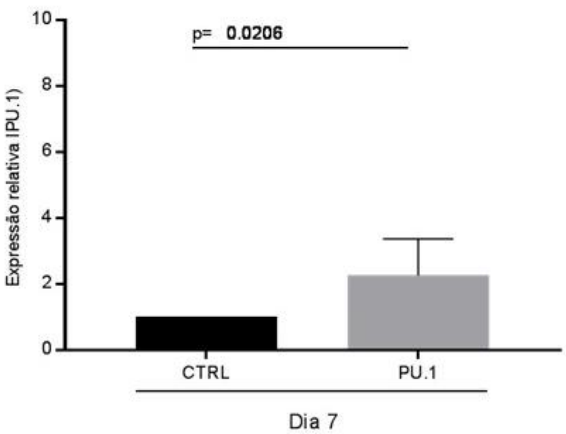

PU.1

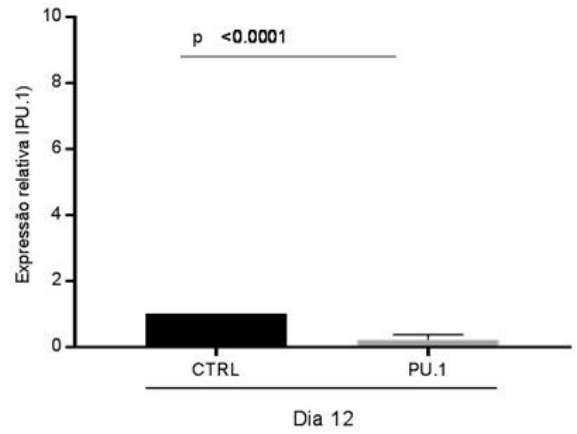

Nos dias 7 e 12 após cocultivo de CTHs com CTMs de indivíduos saudáveis. O RNA total das CTHs foi extraído e a expressão gênica analisada por qPCR. A expressão dos genes de relacionados à diferenciação hematopoética: (A) GATA2, (B) GATA3, (C) IKZF1 e (D) PU.1 foi normalizada pelos genes GAPDH e RPL13a e, expressos como número de vezes em relação ao controle (expressão relativa). Os experimentos foram realizados em triplicata, os resultados representados por média \pm DP e considerados significativos quando $p \leq 0,05$. CTRL: cultivo de apenas CTHs, sem a presença de CTMs. Dia 7: sete dias após o cocultivo de CTHs com CTMs. Dia 12: doze dias após o cocultivo de CTHs com CTMs. CTR $n=02$, CTMs $n=6$.

Figura 1. Expressão dos genes relacionados à diferenciação de linhagens hematopoéticas após cocultivo de CTHs com CTMs 
Apêndice 2. O cocultivo de células-tronco hematopoéticas com células-tronco mesenquimais altera a regulação da expressão gênica do fator de transcrição KLF4 nas células-tronco hematopoéticas

A

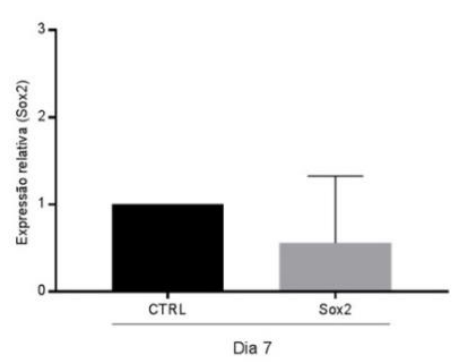

B

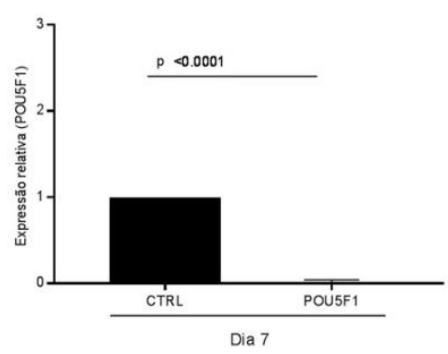

C

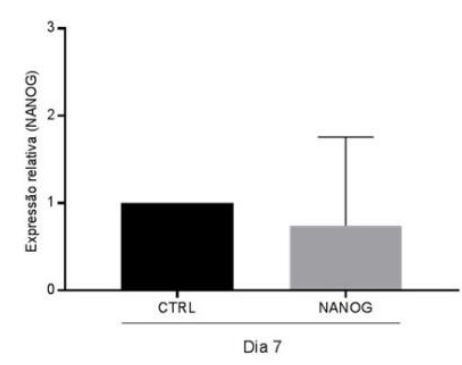

D

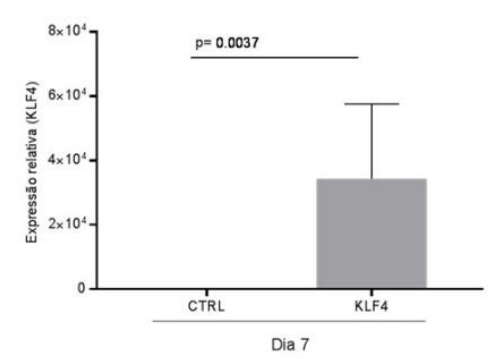

Sox2

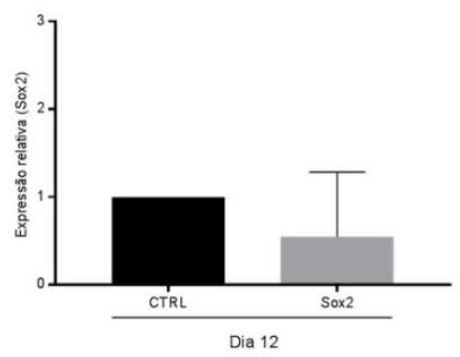

POU5F1

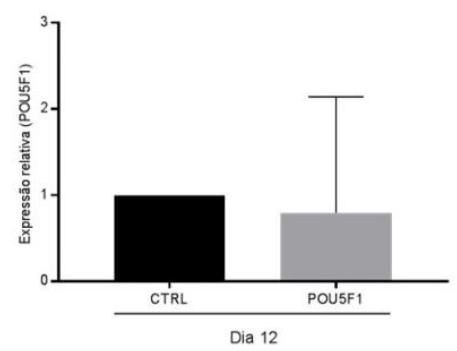

NANOG

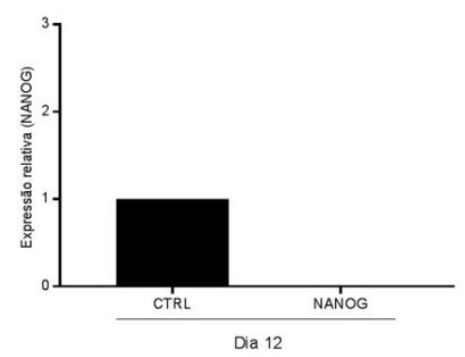

KLF4

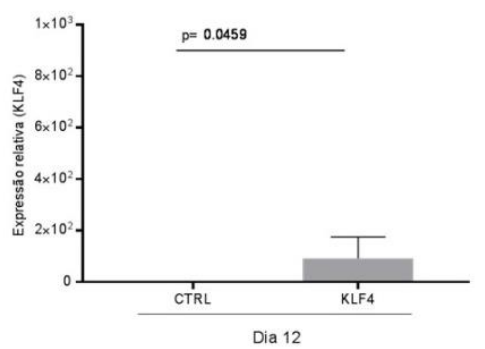

Nos dias 7 e 12 após cocultivo de CTHs com CTMs de indivíduos saudáveis (n=6). O RNA total das CTHs foi extraído e a expressão gênica analisada por qPCR. A expressão relativa dos genes de pluripotência: (A) SOX2, (B) POU5F1 (C) NANOG e (D) KLF4 foi normalizada pelos genes GAPDH e RPL13a (expressão relativa). Os experimentos foram realizados em triplicata, os resultados representados por média \pm DP $\mathrm{e}$ considerados significativos quando $p \leq 0,05$. CTRL: cultivo de apenas CTHs, sem a presença de CTMs. Dia 7: sete dias após o cocultivo de CTHs com CTMs. Dia 12: doze dias após o cocultivo de CTHs com CTMs. CTR $n=02$, CTMs $n=6$.

Figura 2. Expressão dos genes relacionados à pluripotência após cocultivo de CTHs com CTMs 
Apêndice 3. $O$ cocultivo de células-tronco hematopoéticas com células-tronco mesenquimais altera a regulação da expressão gênica da beta-catenina nas célulastronco hematopoéticas
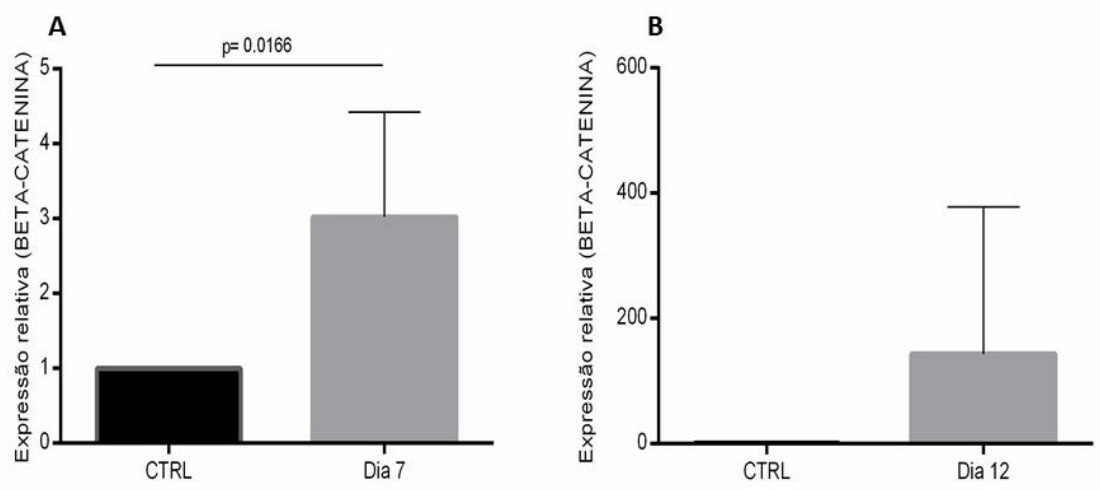

Nos dias 7 e 12 após cocultivo de CTHs com CTMs de indivíduos saudáveis $(n=6)$. O RNA total das CTHs foi extraído e a expressão gênica analisada por qPCR. A expressão relativa do gene da Beta-Catenina foi normalizada pelos genes GAPDH e RPL13a (expressão relativa). Os experimentos foram realizados em triplicata, os resultados representados por média $\pm \mathrm{DP}$ e considerados significativos quando $p \leq 0,05$. CTRL: cultivo de apenas CTHs, sem a presença de CTMs. Dia 7: sete dias após o cocultivo de CTHs com CTMs. Dia 12: doze dias após o cocultivo de CTHs com CTMs.

Figura 3. Expressão gênica da proteína Beta-catenina após cocultivo de CTHs com CTMs 
Apêndice 4. Células-tronco mesenquimais provenientes da medula óssea humana expressam NG2

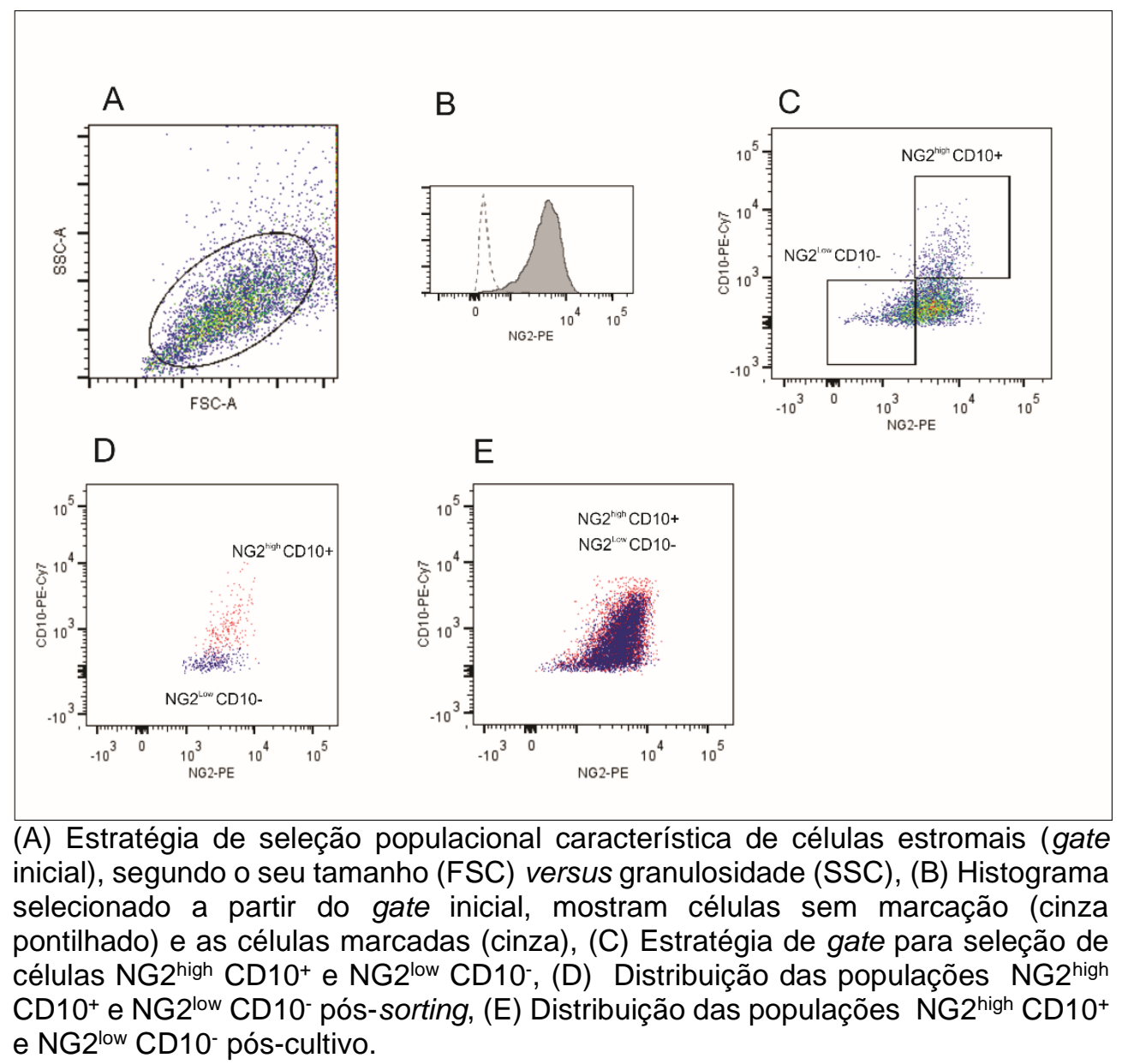

Figura 4. Expressão de NG2/CD10 em CTMs isoladas de medula óssea 
Apêndice 5. Separação das subpopulações de células-tronco mesenquimais NG2 e CD90

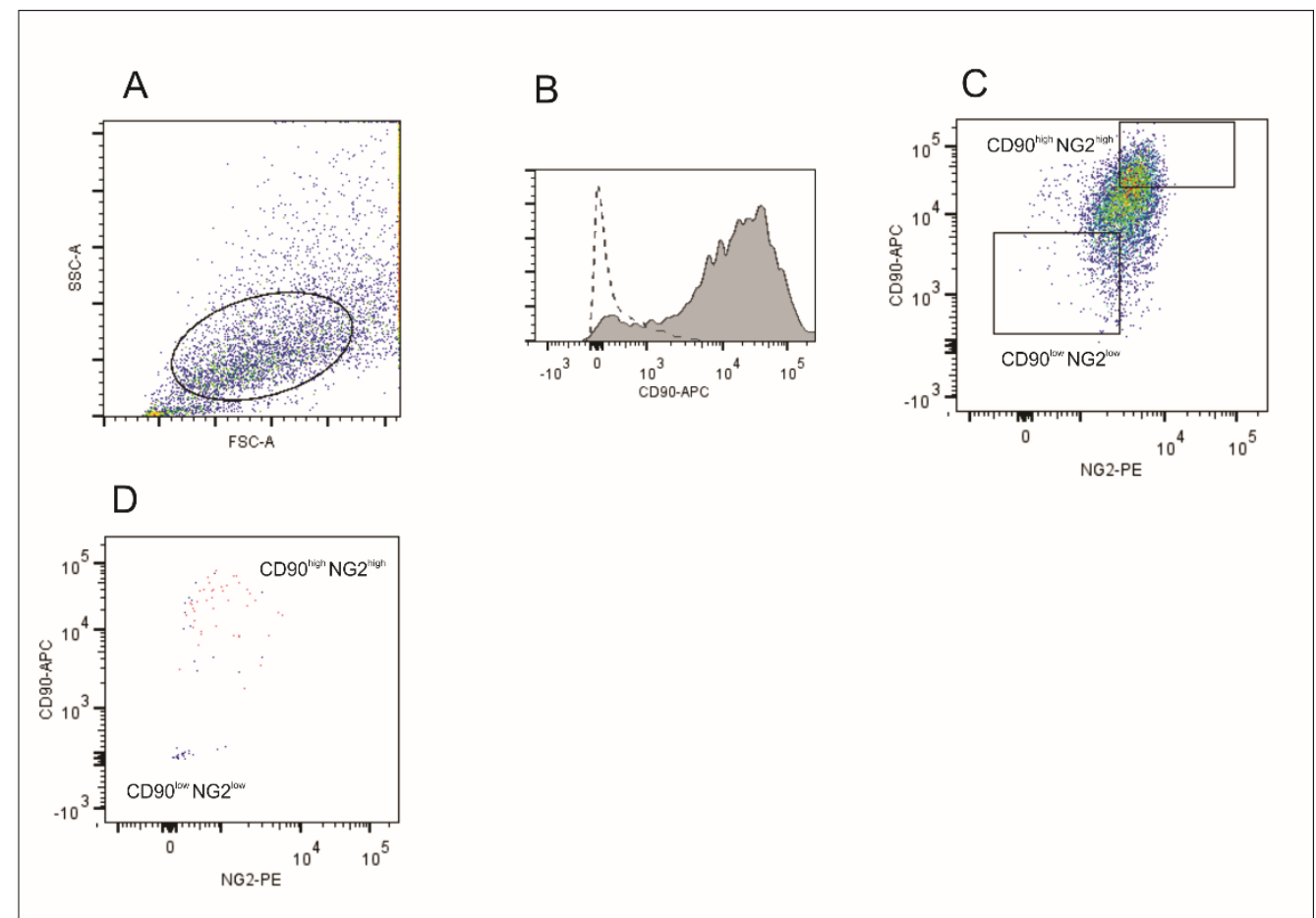

(A) Estratégia de seleção populacional característica de células estromais (gate inicial), segundo o seu tamanho (FSC) versus granulosidade (SSC), (B) Histograma selecionado a partir do gate inicial, mostram células sem marcação (cinza pontilhado) e as células marcadas (cinza), (C) Estratégia de gate para seleção de células NG2high CD90 ${ }^{\text {high }}$ e NG2 ${ }^{\text {low }}$ CD90 low $(D)$ Distribuição das populações NG2 ${ }^{\text {high }}$ CD90 $90^{\text {high }}$ e NG2 low CD90 low pós-sorting.

Figura 5. Expressão de NG2/CD90 em CTMs isoladas de medula óssea 